UNIVERSIDADE DE SÃO PAULO

PROGRAMA DE PÓS-GRADUAÇÃO INTERUNIDADES EM ESTÉTICA E HISTÓRIA DA ARTE

CÁSSIA PÉREZ DA SILVA

A LEGITIMAÇÃO DE ARTISTAS CONTEMPORÂNEOS NO MERCADO DE ARTE NO PONTO DE VISTA DO BRANDING:

O CASO BEATRIZ MILHAZES

SÃO PAULO 


\section{A LEGITIMAÇÃO DE ARTISTAS CONTEMPORÂNEOS NO MERCADO DE ARTE NO PONTO DE VISTA DO BRANDING: \\ O CASO BEATRIZ MILHAZES}

(Versão corrigida)

Dissertação apresentada ao Programa de PósGraduação Interunidades em Estética e História da Arte para a obtenção do título de Mestre, na linha de pesquisa: Produção e circulação da arte.

Orientadora: Profa. Dra. Jane Aparecida Marques.

\section{SÃO PAULO}




\section{ENTREGA DO EXEMPLAR CORRIGIDO DA \\ DISSERTACÃ̃O/TESE \\ Termo de Ciência e Concordância do(a) orientador(a)}

Nome do(a) aluno(a): Cássia Pérez da Silva

Data da defesa: 16/12/2020

Nome do Prof(a). orientador(a): Jane Aparecida Marques

Nos termos da legislação vigente, declaro ESTAR CIENTE do conteúdo deste EXEMPLAR CORRIGIDO elaborado em atenção às sugestões dos membros da comissão Julgadora na sessão de defesa do trabalho, manifestando-me plenamente favorável ao seu encaminhamento e publicação no Portal Digital de Teses da USP.

São Paulo, 05/01/2021

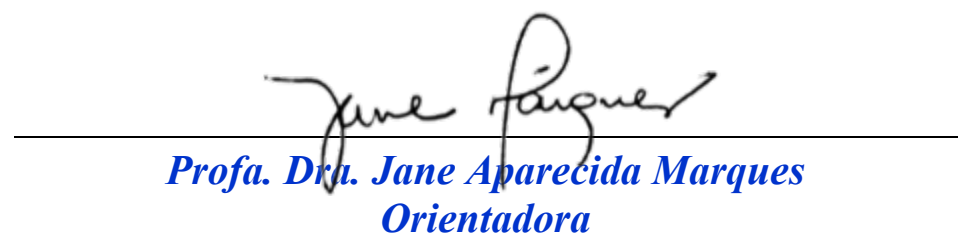


Autorizo a reprodução e divulgação total ou parcial deste trabalho, por qualquer meio convencional ou eletrônico, para fins de estudo e pesquisa, desde que citada a fonte.

Catalogação na Publicação

Serviço de Biblioteca e Documentação

Faculdade de Filosofia, Letras e Ciências Humanas da Universidade de São Paulo

S5861

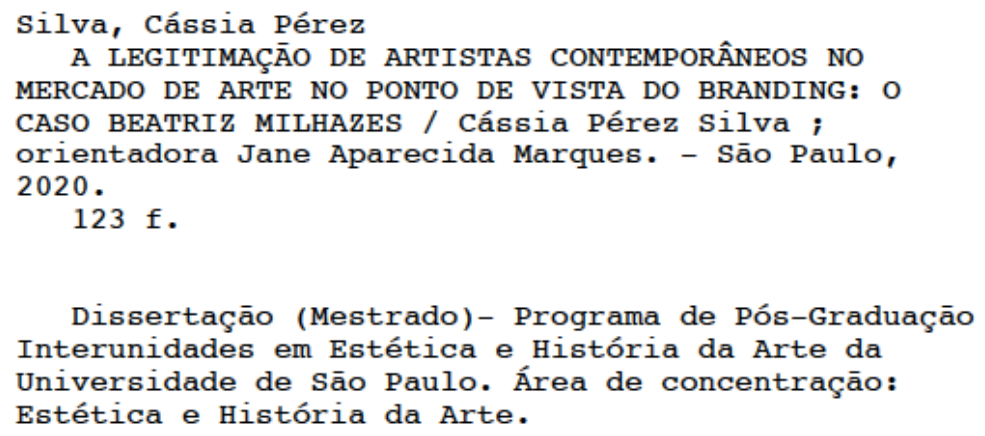

1. arte contemporânea. 2. mercado de arte. 3 . branding. 4. legitimaçāo de artistas. 5. Beatriz Milhazes. I. Marques, Jane Aparecida, orient. II. Título. 
Dissertação apresentada ao Programa de Pós-Graduação Interunidades em Estética e História da Arte da Universidade de São Paulo para a obtenção do título de Mestre em Estética e História da Arte.

Banca Examinadora:

Profa. Dra.: Jane Aparecida Marques

Instituição: Universidade de São Paulo

Julgamento:

Profa. Dra.: Rita de Cássia Giraldi

Instituição: Universidade de São Paulo

Julgamento:

Prof. Dr.: Cauê Alves

Instituição: Pontifícia Universidade Católica de São Paulo

Julgamento:

Prof. Dr.: Miguel Wady Chaia

Instituição: Pontifícia Universidade Católica de São Paulo

Julgamento: 


\section{Para Maria Lucia, Antonio e Seu Zé}

Este trabalho é todo para vocês que, diariamente, me motivam a ser uma pessoa melhor. Sei que em cada página escrita existe um pedaço de vocês que se revela em forma de pesquisa, dedicação e amor. Assim consigo sanar as saudades dos três. 


\section{AGRADECIMENTOS}

Antes de tudo, queria agradecer a minha orientadora Jane Marques por todas as discussões, correções sem fim de artigos e da dissertação, por todas as risadas, pelo companheirismo e principalmente pelos aprendizados com os alunos da EACH. Também preciso agradecer imensamente à Neusa e ao Paulo, da secretaria do Programa por estarem sempre prontos para tirar as mil dúvidas que tive em todo o processo. Na sequência, devo também agradecer à Coordenação de Aperfeiçoamento de Pessoal de Nível Superior pela bolsa que possibilitou a concretização da dissertação.

À minha família, Neide, Paulo e Guilherme, por sempre acreditarem no trabalho até quando ele parecia um sonho distante, por apoiarem todas as minhas loucuras e também por me ensinarem a apagar as más ideias enquanto há tempo. Ao Felipe, por acompanhar esse trabalho desde o primeiro rascunho feito em 2015 na graduação, e depois em todos os desdobramentos que tomou e, também, por estar comigo em todas as ciladas que a vida oferece. Também não posso deixar de agradecer à Mara, Alex, Isaura, Montse, Aura, Arturo, Maribel, Lara, Carol, Lilia, Barbarah, Erico, Ivete, Sabrina e Katherine: minha família agregada que se espalhou pelo mundo, mas que participou ferozmente em todas as etapas deste trabalho em forma de apoio, amor e companheirismo. Aos meus colegas de orientação pelas conversas maravilhosas e muitas risadas, Rosane, Joseane, Raphael e Wladimir.

No que se refere aos conhecimentos ligados à arte, preciso agradecer imensamente à Maria Montero com seu Phosphorus e Sé, ao Cauê Alves, Sônia Régis (in memoriam), Elaine Caramella, Miguel Chaia, Cristina Freire, Ana Magalhães e muitos outros nomes que contribuíram para a minha formação e por me proporcionarem constantes perguntas, sempre me lembrando que quando se trata de arte nunca existe uma verdade absoluta. Gostaria de agradecer também ao querido Ivo Mesquita por tudo que ele contribuiu para que este trabalho tomasse o rumo que tomou.

Por fim, para fazer a lista finita, agradeço aos artistas e a todos os agentes do sistema da arte: pelo esforço, pela ousadia e por sempre tentarem trazer novos questionamentos ao mundo. Em especial à querida Beatriz Milhazes que, sem ela, nada disso seria possível. 


\section{RESUMO}

O propósito desta dissertação é estudar a legitimação de artistas contemporâneos brasileiros e suas inserções no mercado de arte, utilizando-se do conceito de branding para entender como ocorrem esses processos. Elencam-se, assim, como objetivos: analisar o mercado de arte para entender de que maneiras ocorrem as formações de valores das obras de arte e quais as particularidades do mercado de arte brasileiro, compreender como ocorre a legitimação dos artistas, a partir da ótica mercadológica e, por fim, situar a relevância e análise da carreira e dos contextos nos quais a artista Beatriz Milhazes está inserida. O estudo é de natureza exploratória e adotou-se o método de estudo de caso - centrado na trajetória da artista plástica Beatriz Milhazes - e a proposição de Hargreaves McIntyre (2004), que divide o sistema da arte na lógica de ecossistema, para melhor entendimento das etapas de inserção de artistas nesse mercado. Além de levantamento teórico e de dados secundários, foram realizadas entrevistas com um gestor de arte e com a referida artista. Analisamos o mercado de arte brasileiro e as transformações que ocorreram no país, em especial, a partir da 'Geração 80', que resultaram em mudanças na legitimação de artistas contemporâneos inseridos nesse contexto, dentre os quais se destaca Beatriz Milhazes. Nesse sentido, ao investigar o ecossistema de arte, na perspectiva de branding para entender como ocorre a inserção dessa artista contemporânea no mercado de arte, percebemos a autonomia da artista, no que se refere à tomada de decisão acerca de sua carreira e também a importância de suas associações e/ou parcerias para sua permanência no mercado nacional e internacional. Essa autonomia favoreceu a maior profissionalização da carreira profissional de Milhazes e reforçou a esfera empresarial em que a artista está inserida, ressaltando sua legitimação pelo mercado e destacando os valores e os estágios de sua trajetória artística.

Palavras-chave: arte contemporânea; mercado de arte; branding; legitimação de artistas; Beatriz Milhazes. 


\begin{abstract}
The purpose of this dissertation is to study the legitimacy of contemporary Brazilian artists and their insertions in the art market, using the concept of branding to understand how these processes occur. The objetives are to analyze the art market to understand in what ways the value formation of works of art occur and what are the particularities of the Brazilian art market, to understand how the legitimation of artists occurs from the perspective marketing and finally, locate the relevance and analysis of the career and the contexts in which the artist Beatriz Milhazes is inserted. The study is of exploratory nature and the case study method was adopted - centered on the trajectory of the artist Beatriz Milhazes - and the proposition of Hargreaves McIntyre (2004), which divides the art system in the logic of the ecosystem was used for better understanding stages of insertion of artists in this market. In addition to a theoretical survey and secondary data, interviews were conducted with an art manager and with that artist. We analyzed the Brazilian art market and the transformations that took place in the country, especially from the 'Generation 80 ', which resulted in changes in the legitimation of contemporary artists in this context, among which Beatriz Milhazes stands out. In this sense, when investigating the art ecosystem, in the perspective of branding to understand how this contemporary artist inserts into the art market, we perceive the artist's autonomy, with regard to decision making about her career and also the importance associations and / or partnerships to remain in the national and international market. This autonomy favored the greater professionalization of Milhazes' professional career and reinforced the entrepreneurial sphere in which the artist is inserted, emphasizing her legitimation by the market and highlighting the values and stages of her artistic trajectory.
\end{abstract}

Keywords: contemporary art; art market; branding; artist's legitimation; Beatriz Milhazes. 


\section{LISTA DE FIGURAS}

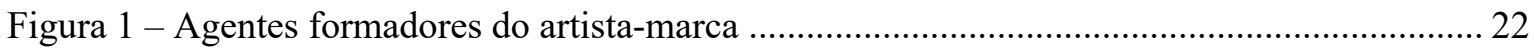

Figura 2 - Introdução do Artista no Mercado de Arte .................................................................... 23

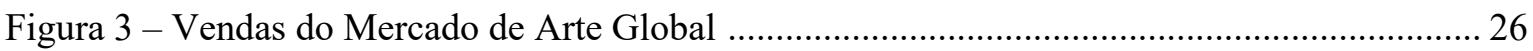

Figura 4 - Mercado Global nas Casas de Leilões Públicas no período de 2009 até 2019 ............... 29

Figura 5 - Mercado Secundário Global dividido por valor em 2019 .............................................. 29

Figura 6 - Principais obstáculos na condução da galeria de arte .................................................... 31

Figura 7 - Tipos de obras vendidas em relação ao total de obras vendidas no Brasil ..................... 33

Figura 8 - Balanço das vendas no Brasil - \% por faixas de valores comerciais .............................. 36

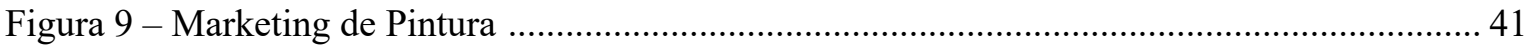

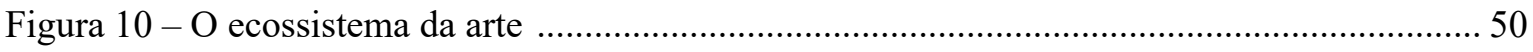

Figura 11 - Cartaz da exposição Quem é você, geração 80?, julho de 1984 .................................... 62

Figura 12 - Obra Nu Azul, de Beatriz Milhazes, acrílico sobre tela (1996), exposta na

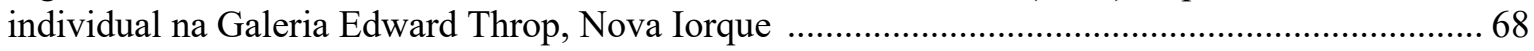

Figura 13 - Vista da obra Gavião e passarinho, de Beatriz Milhazes na 24a Bienal

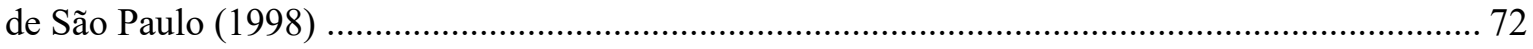

Figura 14 - Obra Gavião e passarinho, acrílico sobre tela, 250 x $350 \mathrm{~cm}$ (1998) .......................... 72

Figura 15 - Obra $O$ mágico, acrílico sobre tela (2001) …………….............................................. 74

Figura 16 - Notícia de jornal acerca de altos valores da artista vendidos na SP-Arte 2016 ........... 75

Figura 17: Países onde realizou exposições individuais (1985 até 2019) ........................................ 76

Figura 18: Países em que realizou exposições coletivas (1985 até 2019) ....................................... 76

Figura 19: Instituições x Galerias Comerciais - exposições individuais (1985 até 2019) ……........ 77

Figura 20: Instituições x Galerias Comerciais - exposições coletivas (1985 até 2019) .................... 78

\section{LISTA DE QUADROS}

Quadro 1 - Ranking dos maiores desafios do mercado primário de 2017 a 2019 


\section{SUMÁRIO}

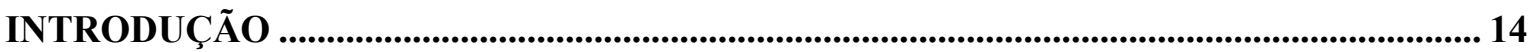

CAPÍTULO I: Noções Preliminares Acerca do Mercado de Arte e a Formação de Valor das Obras Contemporâneas............................................................................................................................... 19

I.1 A criação de valor das obras de arte ……….......................................................... 19

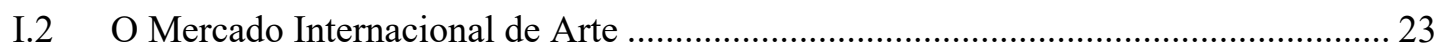

I.3 O Mercado Brasileiro de Arte .................................................................................. 31

I.4. Valores de Obras de Arte Contemporânea....................................................................... 34

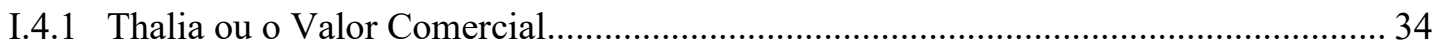

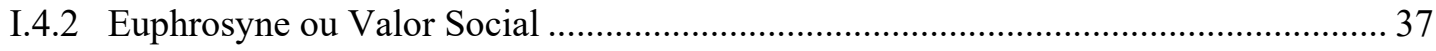

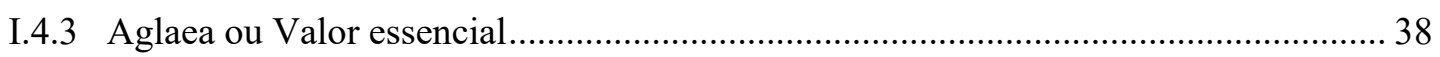

CAPÍTULO II: Processos de legitimação e aplicação do branding na trajetória de artistas

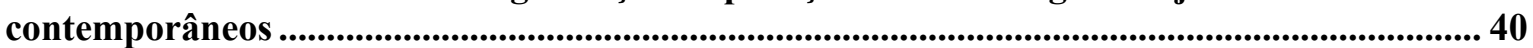

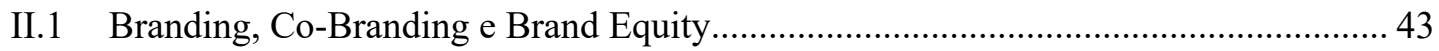

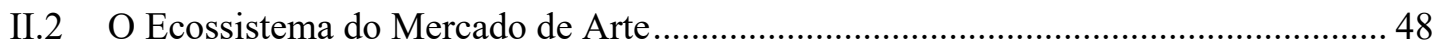

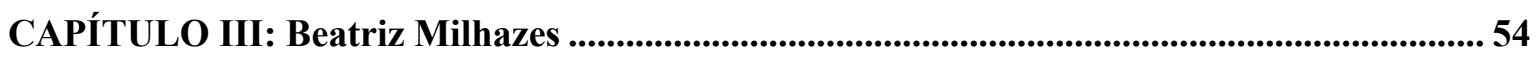

III.1 Contexto sociohistórico da artista no início de sua carreira ........................................ 54

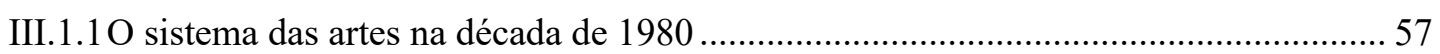

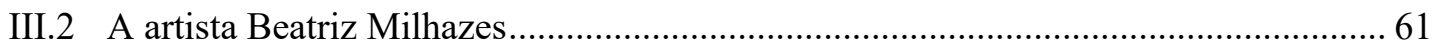

III.2.1 Inserção no mercado de arte nacional e internacional .................................................. 61

III.2.2Estratégias de permanência nos mercados nacional e internacional de arte................. 70

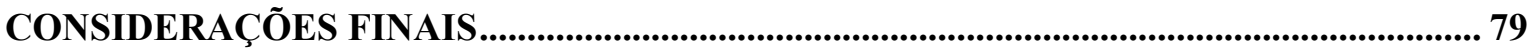

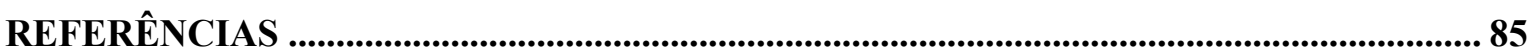

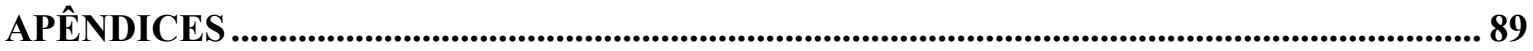

Apêndice A - Roteiro Entrevista com a artista .......................................................................... 89

Apêndice B - Roteiro de Entrevista com agente do sistema.................................................... 90

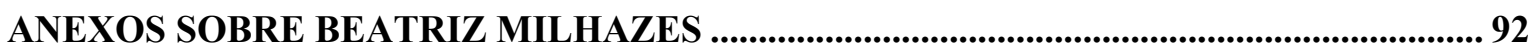

Anexo A - Exposições Individuais .................................................................................... 92

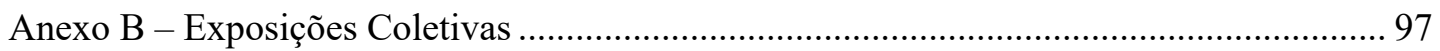

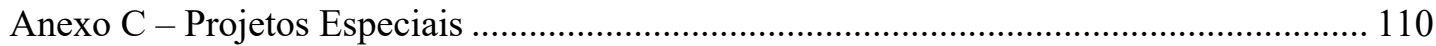

Anexo D - Coleções Públicas ...................................................................................... 112

Anexo E - Livros e Catálogos...................................................................................... 113 


\section{Introdução}

O mercado de arte contemporâneo ganhou espaço nas mídias, especialmente na última década, com destaque para os altos valores das obras e também pelas pessoas bem relacionadas presentes nos eventos de arte. Manchetes como "Tela de Beatriz Milhazes é vendida por R\$16 milhões na abertura da SP-Arte” (MARTI, 2016), alimentam a imagem de artistas como agentes atuantes no sistema, os quais, com suas ações, dentro e fora do circuito de arte, podem afetar a dinâmica de venda e suas atuações dentro do mercado de arte. Essa atuação como agentes sociais é entendida por Lipovetsky (2014) como essencial para a solidificação da marca do artista uma vez que ultrapassa apenas seu produto final (no caso, as obras de arte), mas cria desejos no consumidor acerca de maneiras de consumir a experiência proposta por essa marca.

O termo 'marca' remete para o Marketing, e se refere a um nome, símbolo, desenho - ou uma contribuição desses elementos - que deve identificar os bens ou serviços de uma empresa ou grupo de empresas e diferenciá-los da concorrência (KOTLER, 2000). Uma vez transferida para o âmbito do mercado de arte, uma marca se torna, nas palavras de Don Thompson (2014, p. 100), “o resultado final de uma experiência criada por uma empresa com seus clientes e também à mídia durante um longo período de tempo e a perspicácia do marketing e relações públicas que reforçam esta experiência”, destacando a importância dos agentes culturais para a criação da marca, conceito chamado também de branding.

No que se refere ao branding, no interior do mercado, o conceito está ligado a gestão de marca que, por consequência, se liga a algum produto ou serviço, pois podem ser de naturezas distintas, não necessariamente um bem físico. A ação de estar ligada a uma marca conecta não apenas o produto ao consumidor, mas também engloba o ato de gerir a empresa, realizar a propaganda ideal e atender às demandas de consumo e de mercado. Contudo, o conceito de branding, pensado para um artista, não pode adotar as mesmas estratégias que as adotadas por uma empresa convencional, tendo em vista a especificidade do mercado de arte.

Quando se coloca um artista na perspectiva de fenômeno de branding percebe-se o trabalho em conjunto das mídias, dos teóricos e dos agentes do circuito de arte. A marca do artista não é sedimentada por si só, o que torna os métodos de circulação de extrema importância para que o artista-marca não perca seu lugar no mercado. Tomaremos o conceito 
de processo de legitimação dos artistas para entender de quais maneiras as marcas são criadas e atuam no sistema das artes, analisando quais as estratégias adotadas para que o artista se torne legitimado perante o sistema e também quais estratégias utilizam para permanência. Para a análise dessas estratégias, será utilizada a metodologia desenvolvida por Hargreaves McIntyre (2004), que dividiu o sistema da arte na lógica do ecossistema para maior entendimento das etapas de inserção dos artistas no mercado.

A escolha do artista-marca como tema da pesquisa deve-se a conjunção de fatores como a prévia experiência com a venda de obras de arte em galeria brasileira, aos estudos investigativos iniciais para a realização do Trabalho de Conclusão de Curso Superior. Esses estudos nos indicaram, além de um número reduzido de trabalhos no tocante ao mercado brasileiro de arte, também a necessidade do aprofundamento nas reflexões do papel do branding nas alterações do comércio nacional de arte.

Nesse sentido, parece-nos acertado indicar que, a adequação do tema na linha de pesquisa, dá-se ao investigar as relações e estratégias usadas entre os artistas produtores, os agentes distribuidores e o público receptor/ consumidor. Essa rede de relações é responsável pela permanência e disseminação dos artistas-marca no âmbito do mercado de arte, sendo cada parte dependente das outras, como previsto por McIntyre (2004). A linha de pesquisa de Produção e Circulação da Arte, do Programa de Pós-Graduação Interunidades em Estética e História da Arte, permitiu que a dissertação utilizasse de referências bibliográficas ligadas às mídias, redes sociais e outras fontes de difusão da trajetória da artista analisado, realizando conexões com referenciais acerca da teoria da arte e do marketing, para criarmos ampla análise sobre os artistas-marca e suas atuações no mercado de arte.

No decorrer deste trabalho é analisado o processo de branding no mercado da arte, tendo como referencial as trajetórias, nacional e internacional, da artista contemporânea Beatriz Milhazes, distinguida pelo fomento do debate do que é ser marca no mercado de arte e quais suas consequências. A hipótese que se apresenta é a de que o branding acarreta em uma maior consciência do artista em relação à sua carreira, permitindo que seu processo de legitimação ocorra de maneira consciente e que a marca do artista permaneça sob seu controle mesmo após legitimada perante o sistema.

A artista analisada conforme indicado é Beatriz Milhazes, brasileira com produções iniciadas na década de 1980. Possui obras requisitadas por coleções particulares, ora com maior ou menor valorização no mercado, porém sempre presente tanto no mercado nacional quanto no internacional. Existem fenômenos em sua carreira que justificam suas associações 
ao termo branding, por ultrapassarem o valor monetário de suas obras. Beatriz Milhazes, por exemplo, participa de galerias e eventos com sua produção artística, compondo os pontos necessários para que incidam ações de branding: atende e cria demandas, conquista consumidores, propõe dinâmicas diferenciadas para os mercados de arte nacional e internacional.

Para a efetivação do trabalho foi adotado o estudo de caso (CHIZZOTTI, 2003), referentes a artista Beatriz Milhazes, levantando dados sobre a sua participação nos mercados nacional e internacional de arte. Chizzotti (2003, p. 102), nos indica que "o estudo de caso é uma caracterização abrangente para designar uma diversidade de pesquisas que coletam e registram dados de um caso particular". A delimitação no caso da artista brasileira indica a possibilidade de ampliar o conhecimento e dar significados e referências para a relação mercadológica que vem sendo adotada por ela.

Essa dissertação pode ser configurada como uma investigação exploratória de cunho analítico, fundamentada a partir das estratégias utilizadas pela artista, aqui considerada "marca", seus agentes distribuidores e comercializadores. Os procedimentos metodológicos adotados serviram para analisarmos o mercado de arte brasileiro e internacional e, a seguir, discutimos o valor das obras no mercado de arte, considerando as ideias de Findlay (2012) que distingue três tipos de valores: social, comercial e essencial. Com o diagrama de ecossistema de McIntyre (2004) analisamos as etapas do processo de legitimação e permanência no mercado de Beatriz Milhazes auxiliando-nos a entender as estratégias que ela tem adotado ao longo dos anos.

McIntyre (2004) propõe, por meio do diagrama de ecossistema, 12 (doze) etapas que abrangem desde os estágios iniciais da carreira de um artista até sua fixação e permanência no mercado. Esse diagrama de ecossistema abarca diferentes tipos de combinações dessas etapas, não restringindo a apenas um caminho, o que o torna possível de ser aplicado aos mais diversos perfis de artistas. As etapas serviram de base para entender a trajetória da artista - Beatriz Milhazes. Foram realizadas entrevistas com a artista e com um agente do sistema, visando a aprofundar a análise acerca da legitimação da artista nos mercados nacional e internacional, com apoio de um roteiro baseado nos estudos do mercado de arte, o diagrama de McIntyre (2004) e também o levantamento teórico realizado para esta dissertação.

As informações referentes à artista foram pesquisadas nos meios de comunicação de massa e também da mídia especializada em artes visuais; além de artigos científicos e 
periódicos que tratam do contexto do mercado da arte em que a artista se encontra. Realizamos uma contextualização histórica do início da carreira da artista, na década de 1980 e contemplamos todo seu processo de legitimação, visando a demonstrar que as estratégias adotadas pela artista no momento de sua legitimação acarretaram a sua permanência no mercado de arte até os dias atuais.

Para compor a análise foram levados em consideração os momentos econômicos e políticos que a artista se encontrava no período de sua legitimação, como também qual o público consumidor e a razão pela qual se inicia o consumo exacerbado. Também foram analisados estudos referentes ao mercado de arte brasileiro, visando ao entendimento do funcionamento desse mercado e de quais formas a artista está inserida nele.

Partimos do mercado de arte para analisar as estratégias criativas dos valores presentes na produção de um artista. No que se refere ao comércio, entendemos como agentes primários, as galerias que representam os referidos artistas e realizam as primeiras vendas de suas obras; e também a promoção desses artistas para colocá-los nos parâmetros dos valores comerciais, sociais e essenciais iniciais. Como agentes secundários, temos galerias de revenda de obras, leilões, coleções e colecionadores que revendem obras de arte, a partir de preceitos definidos pelos tipos de valores que se somam no decorrer da trajetória do artista e de suas obras.

Este trabalho procurou entender como é utilizado o branding de artistas contemporâneos, como Beatriz Milhazes, no mercado de arte visando a sua legitimação e permanência no mercado de arte. Definimos, portanto, como objetivo geral compreender como a artista Beatriz Milhazes se torna uma 'marca' (branding) e também como se insere dentro do mercado de arte. No que se refere aos objetivos específicos, temos:

- Analisar o mercado de arte, diferenciando as características dos mercados primário e secundário, visando a compreender como ocorre a formação de valor das obras dos artistas e também quais as particularidades do mercado de arte brasileiro.

- Compreender como ocorre o processo de legitimação da carreira de uma artista a partir da ótica mercadológica, mais especificamente, de branding, sistematizando as suas atuações dentro do mercado da arte, a partir do modelo de ecossistema de Hargreaves McIntyre (2004).

- Situar a relevância e análise da carreira e dos contextos nos quais a artista 
Beatriz Milhazes está inserida. A identificação dessa relevância, no que se refere ao mercado de arte, será ponderada a partir dos conceitos que a aproximam mercadologicamente de uma marca (branding).

O trabalho divide-se em três capítulos, tendo o primeiro focado em análises do mercado de arte e na formação de valores das obras de arte; o segundo focado na discussão acerca da formação do branding e do processo de legitimação de artistas contemporâneos; e, por fim, o terceiro capítulo analisa a inserção da artista Beatriz Milhazes no mercado de arte nacional e internacional, discutindo as estratégias adotadas no início de sua carreira e como estas auxiliaram na sua permanência no mercado de arte. Os apêndices contêm os roteiros de entrevistas realizados com a artista e com um agente do sistema da arte, utilizados para compor a análise referente ao processo de legitimação e as estratégias adotadas pela artista para permanência no mercado de arte. Nos anexos estão os levantamentos realizados que abarcam todas as exposições (individuais, coletivas e projetos especiais) em que a artista participou, além da lista de todos as coleções públicas que possuem obras da artista e as publicações em que existem textos escrito sobre a obra dela. 


\section{Capítulo I: Noções preliminares acerca do mercado de arte e a formação de valor das obras contemporâneas}

Artists today know more. They are aware of the market more than they once were. There seems to be something in the air that art is commerce itself. Jasper Johns, 2008

\section{I.1 A criação de valor das obras de arte}

$\mathrm{Na}$ teoria da arte, é possível perceber artistas sendo vistos como agentes sociais (LIPOVETSKY, 2014). Suas imagens e suas marcas, muitas vezes, ganham mais destaque do que suas produções artísticas. Para entender a produção de arte, os teóricos recorrem constantemente para a trajetória pessoal e o contexto em que o artista está inserido, permitindo ao público entender o seu caminho e mesclar esses conhecimentos com reflexões acerca das obras. A análise de Reitlinger (1982), em relação às vendas em leilões de artistas europeus do século XVII, adiantava que artistas sempre foram "marcas", uma vez que a reputação e o status social elevavam os valores de venda e podiam manipular o desejo dos consumidores pelos artistas.

No momento em que o artista vira uma marca de si próprio, passa a ser esse agente social que atua e se relaciona, segundo critérios instituídos pela marca, ou seja, os critérios estabelecidos pelo artista ou por representantes que atuam nesse mercado (podendo ser: galeristas, curadores, marchands e críticos). Os artistas que se encontram nesse processo de se tornar marca são conhecidos como branded artists, ou seja, aqueles artistas que, além de possuírem obras com alta cotação no mercado de arte, elas garantem, ainda, o retorno social para a marca dos artistas (THOMPSON, 2014). Em inglês, o termo branded artists é usado para se referir aos artistas que cumprem com as primícias das marcas (THOMPSON, 2014), pode ser traduzido para "artistas-marca", termo que estamos adotando neste estudo.

De fato, considerar o artista como uma marca fornece uma oportunidade para considerar o ato coletivo de criação de marca, onde produtores, consumidores e outras partes interessadas coletivamente desenvolvem, 
mantêm e mudam a identidade da marca ao longo do tempo (PREECE; KERRIGAN, 2014, p. 1.209, tradução nossa). ${ }^{1}$

De acordo com Preece e Kerrigan (2015), a marca do artista está relacionada aos agentes externos, uma vez que toda a identidade da marca pode ficar refém de negociações e de múltiplas relações dentro do circuito de arte, saindo do alcance dos artistas. Essa junção do branding de artista com os agentes externos pode ser entendida como co-branding (RODNER; THOMSON, 2013), sendo uma iniciativa usada em conjunto para fomentar os valores simbólicos e monetários da trajetória dos artistas.

Para a área de marketing, marca refere-se a um nome, símbolo, desenho (ou a todos eles em conjunto), que servem para identificar os bens ou serviços de uma empresa ou conglomerado, a fim de diferenciá-los da concorrência (KOTLER, 2000). Para a sobrevivência da marca no mercado, são utilizados parâmetros chamados de brand equity, os valores da marca, que estão diretamente ligados ao nome e aos símbolos da marca. Segundo Aaker (1992), para mensurar os valores são considerados cinco parâmetros: lealdade da marca; reconhecimento do nome da marca; associações da marca percebidas pela qualidade oferecida; e também outros ativos da marca, tais como patentes, canais de relacionamento, entre outros.

Esse método de medição dos valores da marca proposto por Aaker (1992), está ligado diretamente à percepção do consumidor em relação à marca. É seguro afirmar que são valores subjetivos, suscetíveis à opinião do consumidor, do contexto em que ele está inserido e também de como se relaciona com a marca. Caso a marca não atenda a esses parâmetros, o consumidor busca outras marcas que talvez possam lhe agradar, diminuindo o valor da anterior e, no limite, pode acarretar o seu desaparecimento.

Quando Aaker (1992) e Kotler (2000) consideram uma marca referem-se principalmente a produtos a serem comercializados no mercado, entendendo que cada marca busca firmar-se no(s) segmento(s) em que atua(m), visando aumentar seu valor e abranger $\mathrm{o}(\mathrm{s})$ público(s) consumidor(es) de interesse. Os autores não fazem referência diretamente aos artistas visuais ao tratarem do tema, no entanto, vale ressaltar que, tal como um produto tradicional a ser comercializado, o artista também busca se firmar no mercado de arte, ter aceitação do público e de outros agentes do mercado, ser reconhecido pelas suas obras e pela

\footnotetext{
${ }^{1}$ Tradução livre de: In fact, considering the artist as a brand provides an opportunity to consider the collective act of brand making, where producers, consumers and other stakeholders collectively develops, maintain and change brand identity over time (PREECE; KERRIGAN, 2014, p. 1.209).
} 
sua atuação no sistema. Esses parâmetros aproximam-se dos propostos por Aaker (1992) de valor de marca e, para que possam ser viabilizados precisam ser criados valores para as obras de arte. Nesse sentido, utilizaremos a teoria de Findlay (2012), que apresenta os três tipos de valores das obras de arte e analisaremos como estes ocorrem.

Michael Findlay (2012) faz uma analogia sobre o valor da obra de arte a partir das Karitas, as três filhas do deus grego Zeus: Thalia, Euphrosyne e Aglaea (GRIMAL, 1996). Juntas, elas representam o charme; a beleza e a natureza; a criatividade humana e a fertilidade, respectivamente; e suas funções era a de entreter os deuses e seus convidados com suas qualidades. Em analogia, quando trazidas para o contexto do mercado de arte, podemos representá-las como os três componentes do valor da arte: o valor comercial, o social e o essencial (FINDLAY, 2012). O autor afirma que todas as obras de arte possuem potencial para abranger esses três componentes, apesar da instabilidade que o gosto da cultura e o período em questão possam acarretar.

Findlay (2012) entende o valor comercial da obra como baseado na "intenção coletiva", uma vez que não está diretamente ligado ao tamanho ou à função que exerce. O valor é, portanto, fundado em acordos estabelecidos, a partir da lógica de mercado do momento em que se encontra e da cotação monetária, podendo variar e fazer esses valores aumentarem ou diminuírem. Já o valor social é associado à difusão da obra pela história da arte, pela crítica e pela mídia. Quanto mais difundida é a obra nesses meios, maior seu valor social. Por fim, o autor entende que o valor essencial se encontra no simbolismo carregado pela obra, nos possíveis significados e interpretações que englobam o ramo estético, semiótico e também os sentimentos despertados naquele que interage com ela.

A divisão do conceito de valor das obras no mercado de arte nos mostra a importância de uma junção de fatores e agentes na formação desses valores, podendo considerar o processo de gestão da carreira do artista. Quando levado para este âmbito, é possível perceber aproximações da trajetória do artista e de suas obras à de uma 'marca'. Conforme afirmado por Kotler (2000), a marca é um conjunto de elementos que serve para identificar os bens de uma empresa e diferenciá-los da concorrência. Uma vez transferidos para o mercado de arte, entender o artista como marca significa, nas palavras de Thompson (2014, p. 100), "o resultado final de uma experiência criada por uma empresa com seus clientes e também à mídia durante um longo período de tempo e a perspicácia do marketing e relações públicas que reforçam esta experiência". É esse conceito que o autor define como branding. 
Quando analisados os tipos de valor formados pelas obras de arte em conjunto à noção de branding, percebemos que para que os valores se mantenham no mesmo nível ou se elevem é necessário que o artista mantenha as mais diversas relações, permitindo que os agentes se tornem auxiliares para sustentar a sua marca. A Figura 1 apresenta um diagrama em formato Margarida (daisywheel), que separa os componentes que sustentam a marca do artista, ou artista-marca, no decorrer dos anos (aplicável mesmo após o seu falecimento).

Figura 1 - Agentes formadores do artista-marca

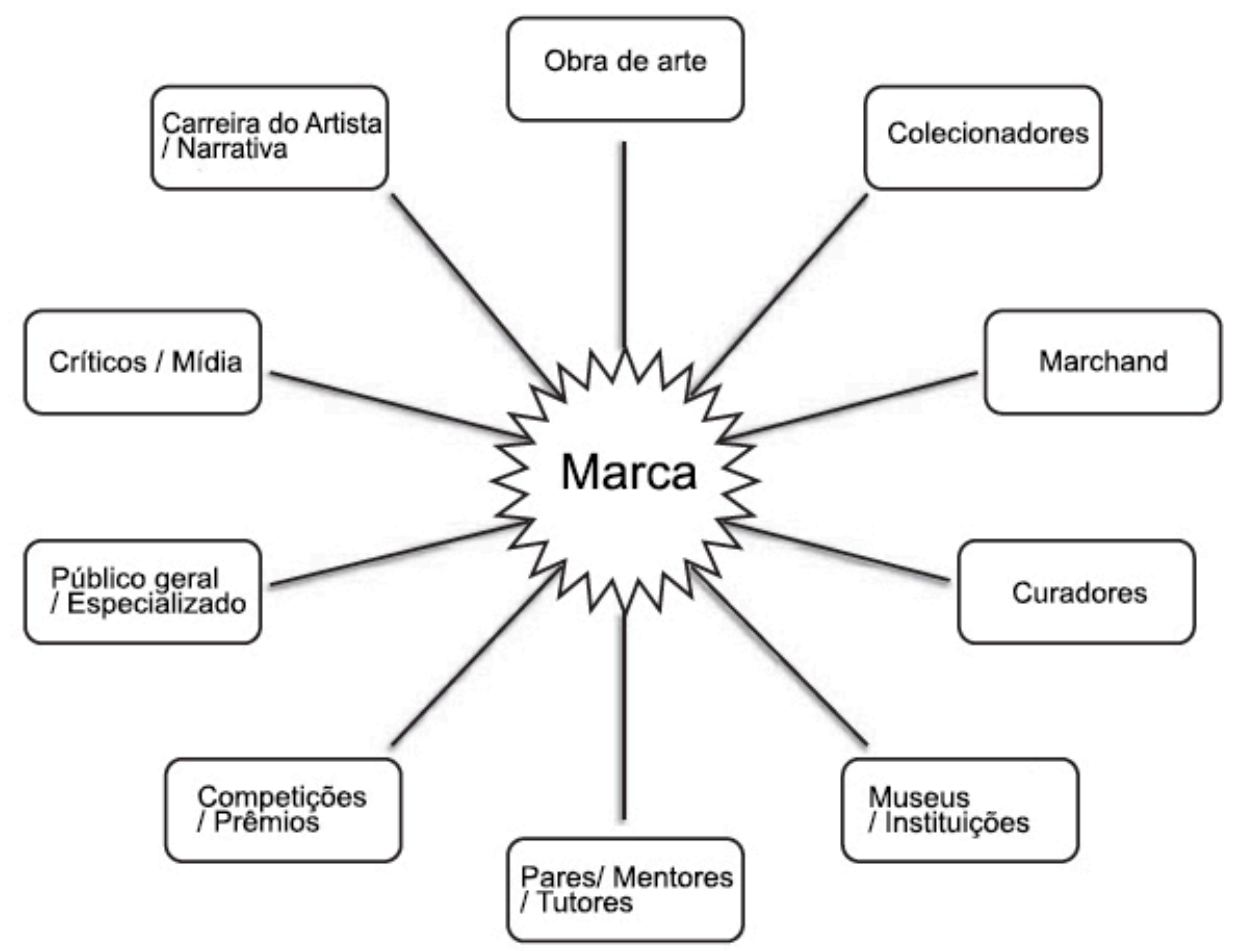

Fonte: Elaborada pela autora, baseada em Preece e Kerrigan (2015).

É importante notar que os componentes apresentados na Figura 1 são, em sua maioria, os mesmos que participam na formação de valores das obras dos artistas. O advento da marca dos artistas, em geral, fica refém de agentes externos que podem, de maneira coletiva, sustentar a marca, melhorá-la ou até mesmo terminá-la, o que pode ser entendido como co-branding (RODNER; THOMSON, 2013): esses agentes também podem ser analisados como marcas e, todos juntos, fazem gestões que se complementam.

Rodner e Thomson (2013) entendem os componentes responsáveis pelo cobranding como também criadores de um aparato da arte (utilizam o termo em inglês art machine), que engloba desde o estágio inicial da carreira do artista, como a formação 
acadêmica, até a aquisição das obras pelos colecionadores de grande porte. Para esses autores, o aparato de arte baseia-se no modelo de ecossistema das artes proposto por Hargreaves McIntyre (2004), que desmembra em partes todo o processo de legitimação da carreira de um artista, conceitos a serem explorados no segundo capítulo deste estudo.

De maneira preliminar, é importante apontar as divisões básicas do mercado de arte internacional e, também, uma contextualização do mercado brasileiro de arte contemporânea para que seja possível o entendimento da formação de valores das obras dos artistas atuais. Sem a atuação direta do mercado primário, ou seja, o mercado que realiza a primeira venda das obras; e a participação do mercado secundário, o mercado que realiza revenda das obras, os valores das obras ficam ausentes de sentido.

\section{I.2 O Mercado Internacional de Arte}

Para que seja possível a existência das Karitas ou os valores da arte (FINDLAY, 2012), faz-se necessária a mediação do mercado de arte entre o artista, os agentes difusores de suas obras (galerias, museus, exposições, feiras, entre outros) e o público consumidor. Esse processo de mediação é um dos fatores chave para que os valores sejam estabelecidos, uma vez que abrange desde a etapa de produção de obra até as revendas no mercado secundário.

Durante o seminário Talking Galleries de 2015, ocorrido em Barcelona, Marek Claassen apresentou um esquema resumido de introdução de um artista no mercado de arte separando as etapas do mercado primário e do secundário, como apresentado na Figura 2.

Figura 2 - Introdução do Artista no Mercado de Arte

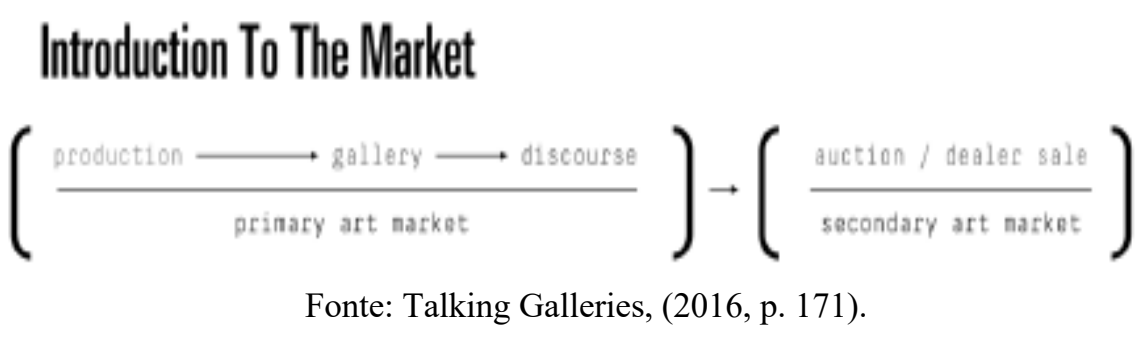


Claassen (TALKING GALERIES, 2016, p. 171) enfatiza a participação da galeria como agente principal no papel de mediação para o mercado primário, tornando-se o veículo de difusão da produção do artista para que museus, colecionadores, pesquisadores e curadores possam ter o primeiro contato com as obras do artista dentro de um contexto institucional. Uma vez introduzido o artista, também é função da galeria a sedimentação de um discurso que possibilite a permanência dele no mercado primário, até mesmo o agente responsável pela internacionalização de suas obras. No esquema apresentado (Figura 2), vemos que o mercado primário faz a preparação de todos os valores para serem englobados pelo mercado secundário. Ao adicionarmos a ideia proposta por Findlay (2012), dos valores da obra de arte, esse esquema evidencia que a produção de discurso para permanência no mercado é o fator que abrange tanto os valores sociais quanto os essenciais, considerando que são a ponte para o mercado secundário.

Geralmente, novos artistas são incorporados à lista da galeria por meio de recomendações de artistas ou de outros especialistas cujo julgamento o negociante de arte confia. Os revendedores representam esses artistas em uma base de consignação: o artista não vende seu trabalho para a galeria, mas o consigna para uma exposição individual ou coletiva. No caso em que o trabalho é vendido, os lucros são divididos de acordo com uma taxa pré-estabelecida. Para os artistas iniciantes, essa relação tende a ser de 50 a 50, mas, uma vez que o artista consiga estabelecer um mercado e uma reputação firmes, ele pode comandar $60 \%$ a $70 \%$ do preço de varejo. Se o trabalho não for vendido, o revendedor poderá mantê-lo no inventário, sem transferência de direitos de propriedade ou o artista poderá retomar o trabalho (VELTHIUS, in TOWLSE, 2011, p. 29, tradução nossa) ${ }^{2}$.

A relação da galeria com os artistas é dada, tal como indicada por Velthius (in TOWLSE, 2011) como dealer (em português, galerista) que, em conjunto com a equipe da galeria, cria o discurso para divulgação e permanência no mercado, no entendimento das melhores estratégias de atuação dos artistas, além de ser a figura que o aproxima para os potenciais consumidores

No mercado de arte primário, os galeristas tendem a representar um número limitado de artistas ( 10 a 30 em média) em longo prazo. O galerista tenta desenvolver um mercado para esses artistas, ou seja, cria demanda entre colecionadores e promove seu trabalho entre especialistas culturais.

2 Tradução livre de: Usually new artists are incorporated into the gallery's roster through recommendations by artists or by other experts whose judgement the art dealer trusts. Dealers represent these artists on a consignment basis: the artist does not sell his/her work to the gallery but consigns it for a solo or group exhibition. In the event that the work is sold, the proceeds are divided according to a pre-established ratio. For starting artists, this ratio tends to be 50-50, but once the artist manages to establish a firm market and reputation, s/he may command 60 or 70 per cent of the retail price. If the work remains unsold, the dealer can either keep it in the inventory, without transfer of property rights or the artist can take the work back (VELTHIUS, in TOWLSE, 2011, p. 29). 
Uma vez que um mercado é estabelecido, o galerista pode protegê-lo, por exemplo, oferecendo preços em leilão, se um trabalho de um dos artistas que ele / ela representa chegar lá. Frequentemente, apenas um pequeno número de artistas que um galerista representa é comercialmente bemsucedido. O lucro obtido com a venda do trabalho desses artistas tende a ser investido nas carreiras dos outros - uma forma de subvenção cruzada (VELTHIUS, in TOWLSE, 2011, p. 29, tradução nossa). ${ }^{3}$

O galerista, representando a sua galeria, e os outros agentes participando da ação de co-branding na carreira dos artistas, ao inseri-los no mercado primário, criam ações conjuntas de estratégias de permanência no mercado de arte.

De acordo com Findlay (2012), para que a obra do artista possua os três tipos de valores (comercial, social e essencial), o mercado primário entra em cena utilizando estratégias que vão desde a programação da galeria até o acompanhamento crítico da obra do artista. No que se refere à programação da galeria, entendemos aqui como: as exposições realizadas nas sedes, eventos ligados às exposições e aos artistas, feiras que frequentam e a participação em conselhos ligados a museus e outras galerias. Essa programação é a coluna dorsal do funcionamento das galerias do mercado primário, ao definir visões, gostos e pretensões que a galeria tem para com os artistas, colecionadores mais assíduos, e as definições dos mercados nacional e internacional a serem atendidos. Essa programação, então, quando colocada em prática, associa-se de maneira direta à criação dos valores nas obras dos artistas ali expostos, uma vez que os apresenta aos potenciais consumidores e/ou compradores e/ou patrocinadores, capazes de criar um discurso de difusão dessa produção, seja por meio de textos acadêmicos, curatoriais, de doações às instituições e também de difusão digital das obras e da trajetória do artista. Os valores apresentados pela galeria ao público final não ocorrem em uma ordem específica: cada galeria propõe uma estratégia em sua programação que facilite o acesso às obras disponíveis para comercialização, podendo mostrar primeiro o valor essencial ao público para só depois apresentar o valor comercial ou o contrário.

\footnotetext{
${ }^{3}$ Tradução livre de: On the primary art market dealers tend to represent a limited number of artists (10-30 on average) on a long-term basis. The dealer tries to develop a market for these artists, or example by creating demand among collectors and by promoting their work among cultural experts. Once a market is established, a dealer may protect it, for instance, by bidding up prices at auction if a work by one of the artists s/he represents comes up there. Frequently, only a small number of artists a dealer represents are commercially successful. The profit $\mathrm{s} / \mathrm{he}$ makes by selling the work of these artists tends to be invested in the careers of the others - a form of cross- subsidization (VELTHIUS, in: TOWLSE, 2011, p. 29).
} 
Segundo dados do Art Market Report, realizado pela TEFAF - The European Fine Art Fair (2017), temos um aumento significativo das vendas realizadas no mercado primário quando inseridas no mercado de arte global, enquanto o mercado secundário teve uma baixa entre 2015 e 2016, conforme apresentado na Figura 3 a seguir.

Figura 3 - Vendas do Mercado de Arte Global

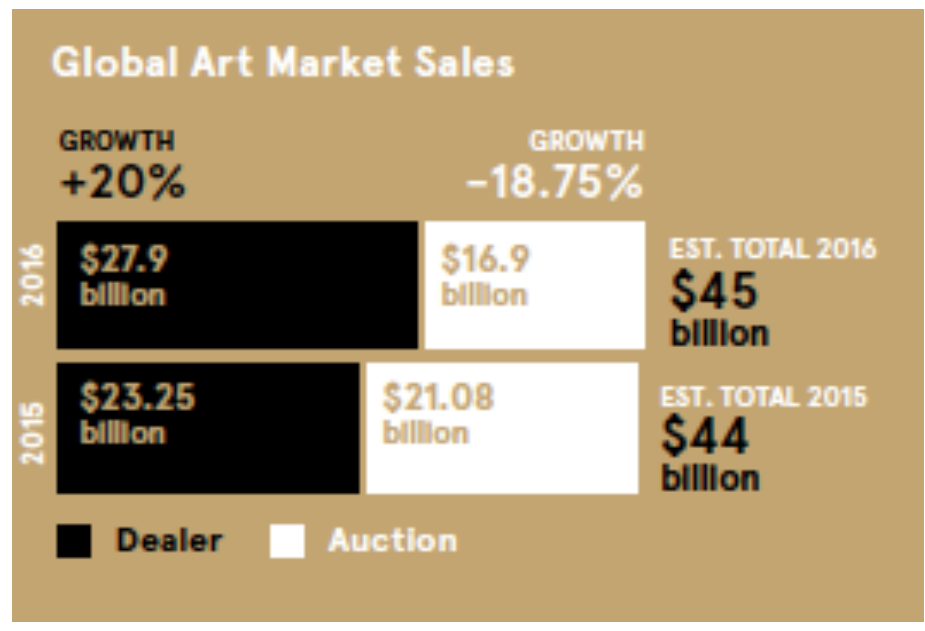

Fonte: Pownal (2018, p. 7).

Entendemos que os programas de internacionalização das galerias contribuem para a elevação dos valores das obras ali comercializadas e também da rede de difusores, porque abrangem um público que não se limita aos frequentadores do local de origem da galeria. Essa internacionalização ocorre das mais diversas maneiras, podendo ser por meio de representações de artistas de localidades geográficas e culturalmente distantes da origem da galeria, seja de outra região ou de um país diferente, ou por meio de parcerias e intercâmbios com galerias estrangeiras. A internacionalização atua como uma estratégia para acessar diferentes mercados, tendo em vista que existem variedades de segmentos para todo tipo de produção, tanto por meio de feiras quanto de exposições com temáticas específicas.

Segundo relatórios da Arte Basel (McANDREW, 2020), as maiores dificuldades de expansão das galerias no ano de 2019, devem-se principalmente à dificuldade em encontrar novos clientes para as obras comercializadas, além dos problemas políticos e econômicos que o mundo tem enfrentado em contexto global, tal como pode ser visto no Quadro 1 a seguir. 
Quadro 1 - Ranking dos maiores desafios do mercado primário de 2017 a 2019

\begin{tabular}{|c|c|c|c|}
\hline Challenge & Rank 2019 & Rank 2018 & Rank 2017 \\
\hline Encontrar novos clientes & 1 & 1 & 1 \\
\hline $\begin{array}{l}\text { A economia / Demanda } \\
\text { para artes e antiguidades }\end{array}$ & 2 & 2 & 2 \\
\hline $\begin{array}{l}\text { Participação em feiras de } \\
\text { arte }\end{array}$ & 3 & 4 & 3 \\
\hline Internet e vendas online & 4 & 6 & 9 \\
\hline $\begin{array}{l}\text { O aumento da regulação } \\
\text { do mercado de arte e os } \\
\text { acordos entre fronteiras }\end{array}$ & 5 & 10 & 11 \\
\hline $\begin{array}{l}\text { Despesas gerais para } \\
\text { instalações comerciais }\end{array}$ & 6 & 7 & 5 \\
\hline $\begin{array}{l}\text { Financiamento do negócio/ } \\
\text { débito }\end{array}$ & 7 & 3 & 8 \\
\hline Instabilidades Políticas & 8 & 9 & 6 \\
\hline $\begin{array}{l}\text { Competição com casas de } \\
\text { leilões }\end{array}$ & 9 & 5 & 4 \\
\hline $\begin{array}{l}\text { Acesso ao fornecimento de } \\
\text { objetos, obras de arte e } \\
\text { artistas }\end{array}$ & 10 & 8 & 7 \\
\hline $\begin{array}{l}\text { Competição com outras } \\
\text { galerias }\end{array}$ & 11 & 11 & 10 \\
\hline $\begin{array}{l}\text { Questões de } \\
\text { sustentabilidade e o } \\
\text { impacto ambiental do } \\
\text { mercado de arte }\end{array}$ & 12 & Não ranqueado & Não ranqueado \\
\hline $\begin{array}{l}\text { Emissões de moeda e } \\
\text { flutuações da taxa de } \\
\text { câmbio }\end{array}$ & 13 & 12 & 12 \\
\hline $\begin{array}{l}\text { Novas tecnologias e seus } \\
\text { efeitos nos negócios }\end{array}$ & 14 & Não ranqueado & Não ranqueado \\
\hline
\end{tabular}

Fonte: McAndrew (2020, p. 119).

A projeção feita pelos agentes entrevistados para a coleta dos dados da Art Basel (McANDREW, 2020) é que, nos próximos cinco anos, essas dificuldades não devem sofrer grandes diferenças, permanecendo em primeiro lugar o desafio de encontrar novos clientes. No entanto, a entrevista ocorreu anteriormente à pandemia resultante da difusão do vírus Covid-19, que assolou todo o mundo, sendo provável que essas tendências se alterem. Uma vez que impossibilitou a ocorrência de feiras, exposições e todo tipo de trocas presenciais no ano de 2020, dessa maneira dificultando ainda mais na busca de novos clientes, que já era apontado como o maior desafio dos próximos anos. Em comparação ao mercado secundário, o mercado primário sofre baixas de acordo com os conflitos existentes no momento considerado, sendo um investimento de risco para os consumidores quando feito 
em momentos de crise, diferentemente do mercado secundário que, como veremos a seguir, faz a revenda de obras que já estão inseridas no circuito das artes.

O mercado secundário se apropria dos discursos criados pelo mercado primário e também dos discursos instituídos por curadores, críticos de arte, historiadores, entre outros agentes de co-branding, para que seja refeita a revenda das obras. Popularmente, o mercado secundário é mais conhecido pelas casas de leilão internacionais Sotheby's ${ }^{4}$ e Christie's ${ }^{5}$, ambas europeias e de tradição de vendas de mercadorias de luxo; mas existem galerias e escritórios especializados apenas em revendas de obras.

Atualmente as casas de leilão que têm maior número de vendas, garantindo $60 \%$ das vendas do mercado secundário mundial, de acordo com o Art Basel Report (2020), são Christie's, Sotheby's, Poly Auction ${ }^{6}$, China Guardian ${ }^{7}$ e Heritage Auctions ${ }^{8}$, sendo estas concentradas na Europa, América do Norte e Ásia, os maiores consumidores do mercado secundário do mundo.

Concentrado principalmente na Inglaterra, Estados Unidos e China, o mercado secundário possui pouca participação de países latino-americanos e africanos, como é possível observar na Figura 4:

\footnotetext{
${ }^{4}$ Fundada em 1744, a Sotheby's é uma das casas de leilão mais antiga, possui mais de 80 escritórios no mundo todo e comercializa anualmente cerca de US\$4 bilhões. Para mais informações, acessar: https://www.sothebys.com/en/about/our-history.

${ }^{5}$ Fundada em 1766, a Christie's possui escritórios em 46 países do mundo, realiza cerca de 350 leilões anualmente em 80 categorias diferentes, incluindo arte, joias, vinhos, entre outros. Para mais informações, acessar: https://www.christies.com/about-us/welcome-to-christies.

${ }^{6}$ Poly Auction é uma casa de leilão que possui sua base na China, fundada em 2005, sendo a maior do país e a que mais conecta a arte oriental com a ocidental, promovendo as produções locais para o mundo. Para mais informações, acessar: http://en.polypm.artron.net/english/recruite.php.

${ }^{7}$ Baseada na China, a casa de leilão China Guardian fundada em 1993, tem o intuito de realizar vendas em escala mundial de peças tradicionais e obras contemporâneas. Atualmente possui também uma base em Hong Kong e pretende abrir mais escritórios pela Ásia. Para mais informações, acessar: http://www.cguardian.com.hk/en/about/.

${ }^{8}$ Criada em 1976, a Heritage Auctions tem sua base nos Estados Unidos e dez escritórios em outros países, abarcando diferentes tipos de elementos nos seus eventos, como arte moderna, contemporânea, ilustrações, vinhos, joias, entre outros. Para mais informações, acessar: https://www.ha.com/c/about.zx?ic=footer-about-us-060716.
} 
Figura 4 - Mercado Global nas Casas de Leilões Públicas no período de 2009 até 2019

Billion \$

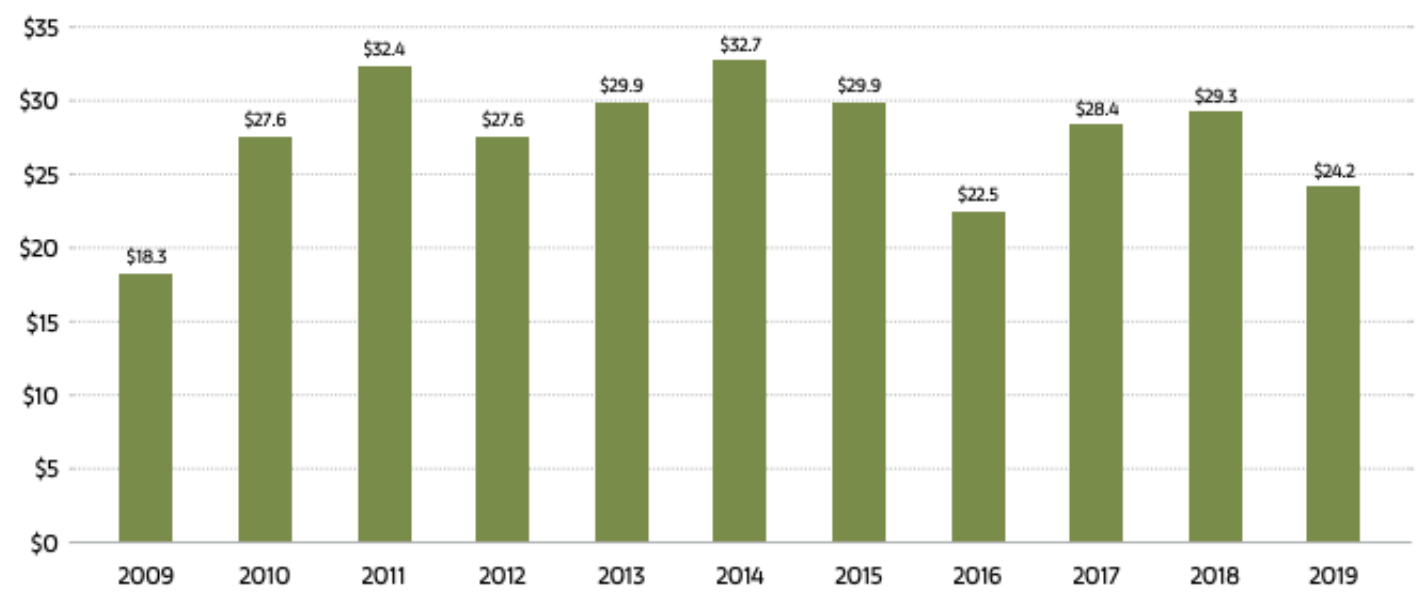

Fonte: McAndrew (2020, p. 127).

Figura 5 - Mercado Secundário Global dividido por valor em 2019

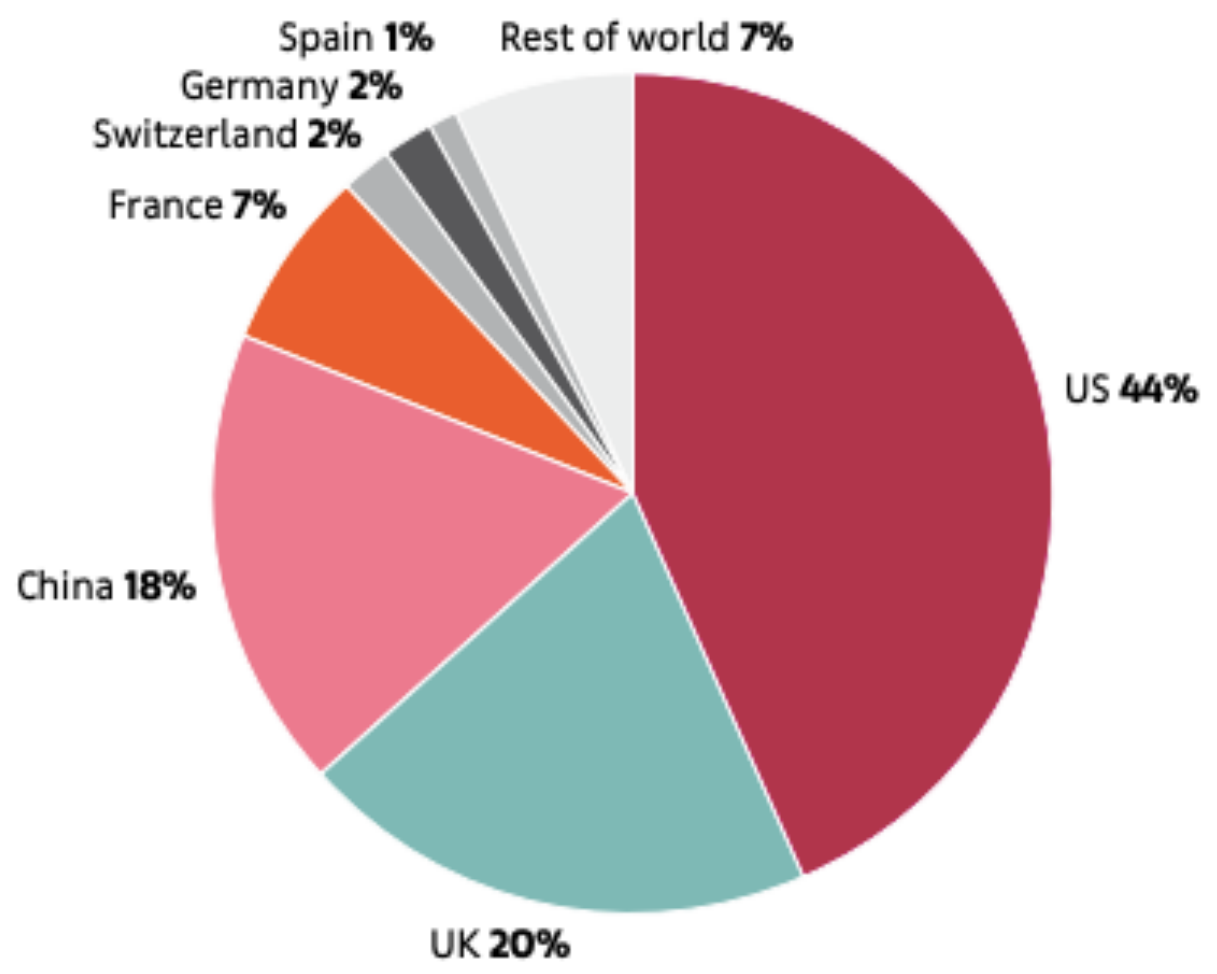

Fonte: McAndrew (2020, p. 36).

Apesar de dependente do mercado primário, o secundário avalia de forma independente os componentes que podem interferir na criação do valor comercial final: como as obras já circulam no mercado das artes, o discurso já existe e está sedimentado, 
tornando necessária apenas a adaptação, conforme os caminhos que a obra atravessou até sua chegada ao mercado secundário. O mercado primário cria o discurso de maneira sutil para que ocorra uma narrativa coerente com a trajetória do artista, visando sedimentar sua carreira (valor social e essencial). $\mathrm{O}$ mercado secundário, no entanto, utiliza-se principalmente do valor social para realizar a venda das obras, deixando de lado muitas vezes o valor essencial.

No mercado secundário, diferente do primário, o valor comercial angariado pela venda não é repassado ao artista na maior parte dos casos, mas ao seu antigo dono e também há uma porcentagem para o leiloeiro e para a casa de leilão (quando a venda é realizada desta maneira). Ashenfelter e Graddy (in TOWLSE, 2011, p. 19), ao analisarem as formas de distribuição da receita adquirida pelas obras, afirmam que

Em princípio, o leiloeiro atua em nome do vendedor, mas a casa de leilões normalmente recebe uma compensação tanto do comprador quanto do vendedor pelos itens vendidos. O prêmio do comprador é uma porcentagem do preço de venda pago ao leiloeiro pelo comprador.

Na maioria das casas de leilão, o prêmio do comprador varia de 10 a $25 \%$ do preço de venda, geralmente uma fração menor de vendas de maior valor (tradução nossa). ${ }^{9}$

Em contraponto com a queda de 2016, o mercado secundário teve um aumento considerável em 2018 e 2019, como é possível observar na Figura 6, devido principalmente às instabilidades políticas nos países e a insegurança de investimento em obras inéditas (McANDREW, 2020).

Tal como visto nas dificuldades apresentadas pelo mercado primário para crescimento em 2019 (Quadro 1), o aumento da procura por obras de artistas já consagrados é fator essencial para o aumento das vendas no mercado secundário em 2019, tendo crescimento previsto para os próximos cinco anos.

\footnotetext{
${ }^{9}$ Tradução livre de: In principle the auctioneer acts on behalf of the seller, but the auction house typically receives compensation from both the buyer and the seller for items that are sold. The buyer's premium is a percentage of the sale price paid to the auctioneer by the buyer. In most auction houses, the buyer's premium varies from 10 to 25 per cent of the sale price, typically being a lower fraction of higher-valued sales (ASHENFELTER; GRADDY, in TOWLSE, 2011, p. 19).
} 


\section{I.3 O Mercado Brasileiro de Arte}

No que se refere ao mercado brasileiro de arte, existe uma concentração no eixo Rio de Janeiro - São Paulo, onde grande parte das galerias comerciais estão localizadas (tanto às pertencentes ao mercado primário, quanto às do secundário). Segundo o Sector Study Report realizado pela plataforma Latitude no ano de 2018, apenas $16 \%$ das galerias participantes possuíam sede em outro estado brasileiro fora desse eixo, com destaque para Curitiba (Paraná). Considerando a extensão geográfica do país, esse eixo abarca apenas uma pequena parcela de toda a produção artística nacional. O mercado brasileiro de arte, portanto, concentra-se principalmente nas regiões sudeste e sul, tornando-o restrito em outras regiões.

As maiores dificuldades para uma galeria de arte do mercado primário se estabelecer no Brasil são: a contínua instabilidade financeira do país, e o alto custo de participação em feiras internacionais (JORDÃO, 2018). Esse fato obriga muitas das galerias a diminuir o número de funcionários constantemente $\mathrm{e}$ também a minimizar a internacionalização de sua programação devido aos altos custos, tal como observado na Figura 6.

Figura 6 - Principais obstáculos na condução da galeria de arte

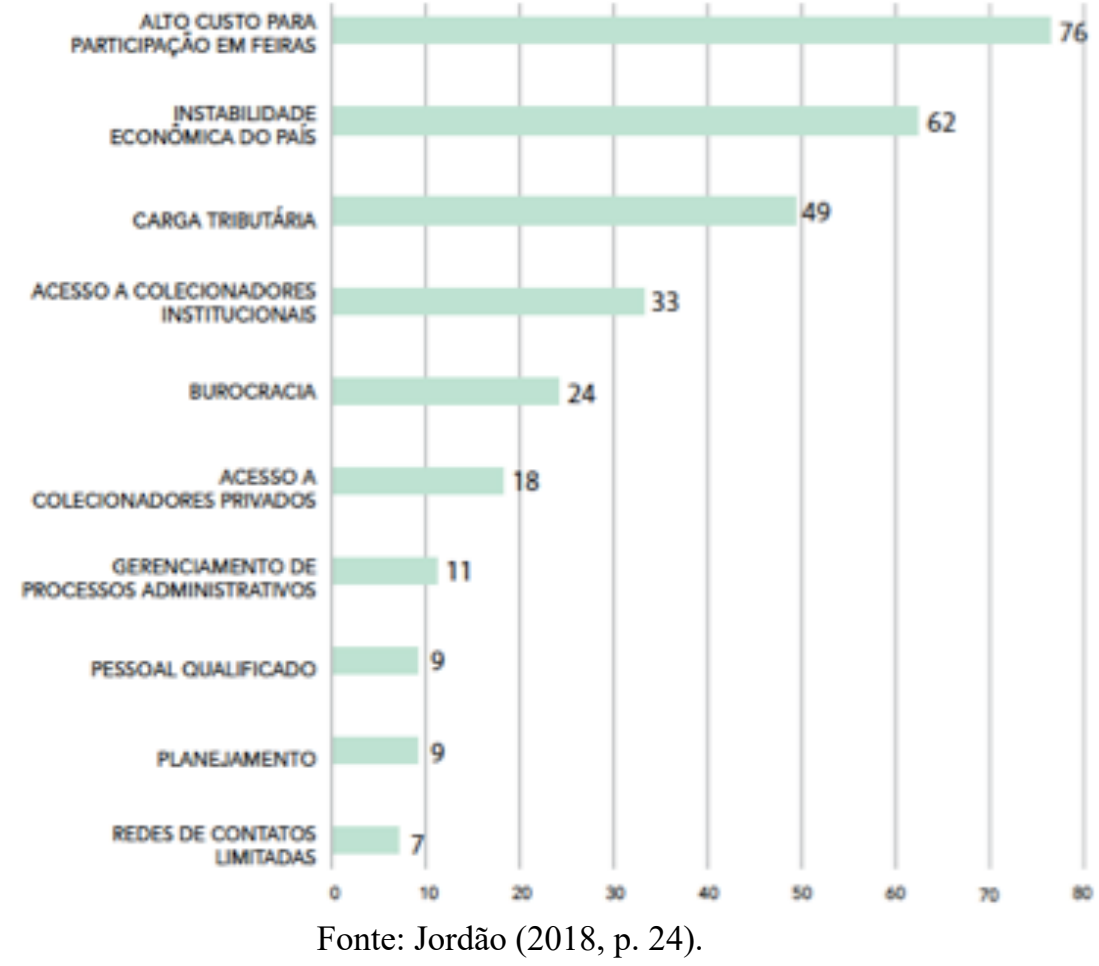


No toante à representação de artistas pelas galerias, constatamos que em sua maioria são brasileiros e moradores do eixo Rio de Janeiro - São Paulo. Isso ocorre principalmente devido à instabilidade financeira causada pelo alto custo das logísticas internas, uma vez que essas localizações tornam o transporte e o contato com a(s) obra(s) menos onerosos do que se estivessem sediados em outros municípios/ estados.

Uma das estratégias de diminuição de custos e de melhorias de condição de trabalho para as galerias é o estabelecimento de parcerias com outras galerias (dos mercados primário e secundário) e diferentes instituições, permitindo assim que os consumidores possam ter um maior acesso às obras e, no longo prazo, uma participação mais ativa no mercado secundário. Tal como ocorre no contexto global, o mercado primário brasileiro teve um crescimento significativo nos últimos anos, apesar da instabilidade econômica e das dificuldades de se estabelecer no país. Fator contribuinte para isso são as feiras de arte, tendo as cifras de vendas a cada ano mais elevadas. As feiras atraem galerias e públicos de diversos países, aumentando o intercâmbio e a internacionalização da arte brasileira; e, além disso, as feiras contam com melhores condições fiscais para os compradores, tornando-se um local atrativo para transações do mercado de arte.

A formação das Karitas (valores) no mercado da arte brasileiro, portanto, ocorre com particularidades distintas ao de outros países no mercado global, uma vez que as dinâmicas aqui realizadas se adaptam à economia local e também ao consumo local (FINDLAY, 2012). Em sua maioria, as obras são vendidas no âmbito nacional, o mercado doméstico, principalmente para colecionadores privados. A relação das galerias com as coleções privadas é um dos fatores de destaque na formação de valor das obras, uma vez que esses agentes são os primeiros investidores da produção de um artista iniciante, não somente na compra das obras, mas também na difusão delas. Essa relação configura os valores comerciais e sociais da obra dos artistas brasileiros, podendo acarretar o crescimento significativo dessa produção.

Como se trata de um mercado jovem em relação ao mercado global, os suportes das obras comercializadas pelo mercado primário são, na maioria, mais tradicionais, tais como pintura e escultura; sendo os vídeos e as instalações os menos comercializados. Nota-se que o discurso criado pelas galerias dá preferência para obras "mais palpáveis" para um consumidor tradicional, deixando de lado formatos que geram dificuldades de exibição e/ou armazenamento. Das 6.000 obras de arte vendidas no ano de 2017 no Brasil, apenas 2\% referem-se a vídeos, enquanto pinturas somam 49\%, como ilustrado na figura abaixo. 
Figura 7 - Tipos de obras vendidas em relação ao total de obras vendidas no Brasil

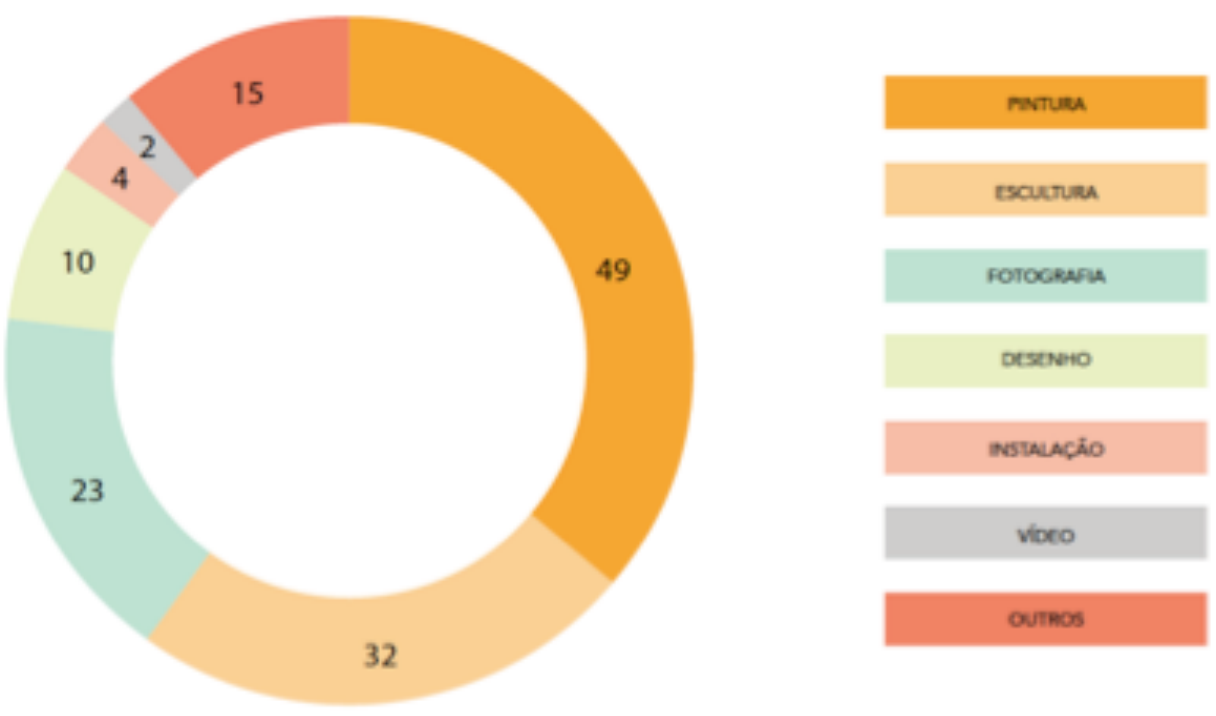

Fonte: Jordão (2018, p. 14).

Esses suportes são reflexos do público consumidor, que mantém coleções privadas em sua maioria, demonstrando o avanço gradual no consumo de arte contemporânea A escolha dos suportes também se reflete na criação dos valores das obras, em virtude do seu fluxo que, em geral, é realizado pelos agentes participantes do circuito da arte. Retomando à dificuldade financeira é possível concluir que os gastos com a produção e exibição de vídeos e instalações são elevados em comparação às pinturas e esculturas, uma vez que precisam de equipamentos específicos que, no longo prazo, correm o risco de se tornarem obsoletos. Ficam, portanto, em segundo plano no contexto do mercado de arte doméstico brasileiro.

O mercado brasileiro primário possui estudos específicos e relatórios anuais, tais como o projeto Latitude da ABACT $(2013,2014,2015,2016,2017,2018)$, que possibilitam a pesquisa com números oficiais. O mercado secundário, no entanto, atua de maneira independente e não consta dos relatórios obtidos para este estudo. Apesar de muitas galerias atuarem no mercado primário e secundário, não costumam divulgar os dados para análise anual da parte atuante no mercado secundário. 


\section{I.4. Valores de Obras de Arte Contemporânea}

\section{I.4.1 Thalia ou o Valor Comercial}

Baseado na intenção coletiva, o valor comercial depende da variação dos outros tipos de valor para sofrer alterações. Nesse sentido, as particularidades das obras são fatores a serem considerados. Segundo Findlay (2012), para que o valor de comercial de uma obra seja criado deve considerar os seguintes aspectos:

- Procedência;

- Condição;

- Autenticidade;

- Exposição;

- Qualidade.

Esses aspectos são considerados para ambos os mercados: primário e secundário, variando com a evolução da carreira do artista. Drummond (2006), divide a carreira do artista em 5 estágios: criação, oferta, interpretação, inserção e consumo. O estágio de criação consiste no tempo entre o nascimento e a morte do artista, no qual ele cria obras e narrativas para serem apresentadas ao público, reconhecendo o artista como um agente cultural e podendo ser medida a relevância que obteve durante o tempo que que viveu. $O$ estágio de oferta ocorre quando as obras começam a ser vendidas e assimiladas pelo mercado, podendo ocorrer simultaneamente ao estágio de criação. A interpretação vai ao encontro das Figuras 1 e 2, baseando-se na criação de discurso para a difusão das obras do artista, ocorrendo em conjunto a outros agentes do sistema. Os dois últimos estágios, inserção e consumo, só conseguem ocorrer com um discurso que esteja sedimentado a ponto de rápida assimilação do público ao artista: envolve a participação em exposições de grande porte ao redor do mundo, aceitação do público com o discurso já existente, procura de novas formas de analisar as obras e, por fim, consumo da marca do artista para além de compra de obras, podendo ocorrer por livros, programas de televisão, merchandising, entre outros. Esses estágios da carreira tornam possível que os valores não sejam fixos, mas mutáveis de acordo com a passagem por eles. 
Quando consideramos os valores, vale ressaltar que exposição e qualidade são aspectos presentes no valor social e essencial da obra, mas estes são acoplados para o comercial e pode alterá-lo de maneira a atingir valores exorbitantes ou até mesmo muito baixos. Esses aspectos auxiliam o valor comercial a sofrer alterações, pois são mutáveis e oscilam de acordo com a obra do artista e o tempo de sua divulgação e/ou comercialização, podendo um mesmo artista possuir valores muito distintos entre suas obras ao longo do tempo.

As obras de um artista que são mais bem recebidas pela crítica e pelos consumidores são as que atingem maior valor comercial. em geral, são essas as que têm grande difusão e elementos estéticos e filosóficos congruentes com a pesquisa do artista, em relação ao contexto no qual se insere. Considerando o mercado secundário, a qualidade em que a obra se encontra e por quais caminhos ela passou (quais foram os possuidores anteriores, e em quais instituições e/ou eventos já foi exibida) determinam as flutuações nos valores. Muitas vezes uma obra que teria potencial para um alto valor, por estar em más condições de conservação, sofre queda significativa no valor comercial.

O valor comercial é, portanto, usado como argumento para transformar as obras em investimento ou especulação, alimentado pela manipulação dos outros valores com o intuito de elevar o preço da obra de arte. As obras tornam-se, então, ativos financeiros quando colocados sob a ótica do mercado, e podem ser classificados como investimentos de risco e, muitas vezes, sem liquidez, considerando que as variações dos valores são subjetivas e sujeitas à mudança radical de acordo com o contexto.

Do ponto de vista simplesmente econômico, entretanto, é um bem infungível, durável e estocável, que não se destrói pelo consumo; é bem móvel, de fácil circulação, o que facilita sua utilização no mercado clandestino, subterrâneo, informal ou paralelo; é bem público, quando em museus, pinacotecas e centros culturais, ou privado, quando em propriedade particular ou de colecionadores; é bem único, insubstituível; é bem estéril como o ouro, mas apesar de não ser rentável, é bem econômico de "refúgio", bem de investimento, bem financeiro, bem de especulação. E, embora passível de cotação no mercado, não se assemelha às ações ou ao ouro, porque só é transacionada comercialmente em galerias, leilões e estabelecimentos especializados ou, então, diretamente pelo artistaprodutor (economia informal) (PINHO, 1989, p. 59).

Notamos no mercado brasileiro de arte que as faixas de valores comerciais que possuem um maior percentual de vendas estão entre $\mathrm{R} \$ 1.000$ e $\mathrm{R} \$ 3.600$, totalizando $29 \%$ dos negócios realizados; enquanto as vendas de valores mais altos, até $\mathrm{R} \$ 100.000$, apenas atingem 4\% do total da comercialização no ano de 2017, tal como apontado na Figura 8. Os 
baixos valores constituem a principal faixa de venda das galerias do mercado primário brasileiro e decorrem das dificuldades tratadas acima, além de também indicar um perfil de colecionadores, que optam por investir em obras com baixo custo.

Figura 8 - Balanço das vendas no Brasil - \% por faixas de valores comerciais
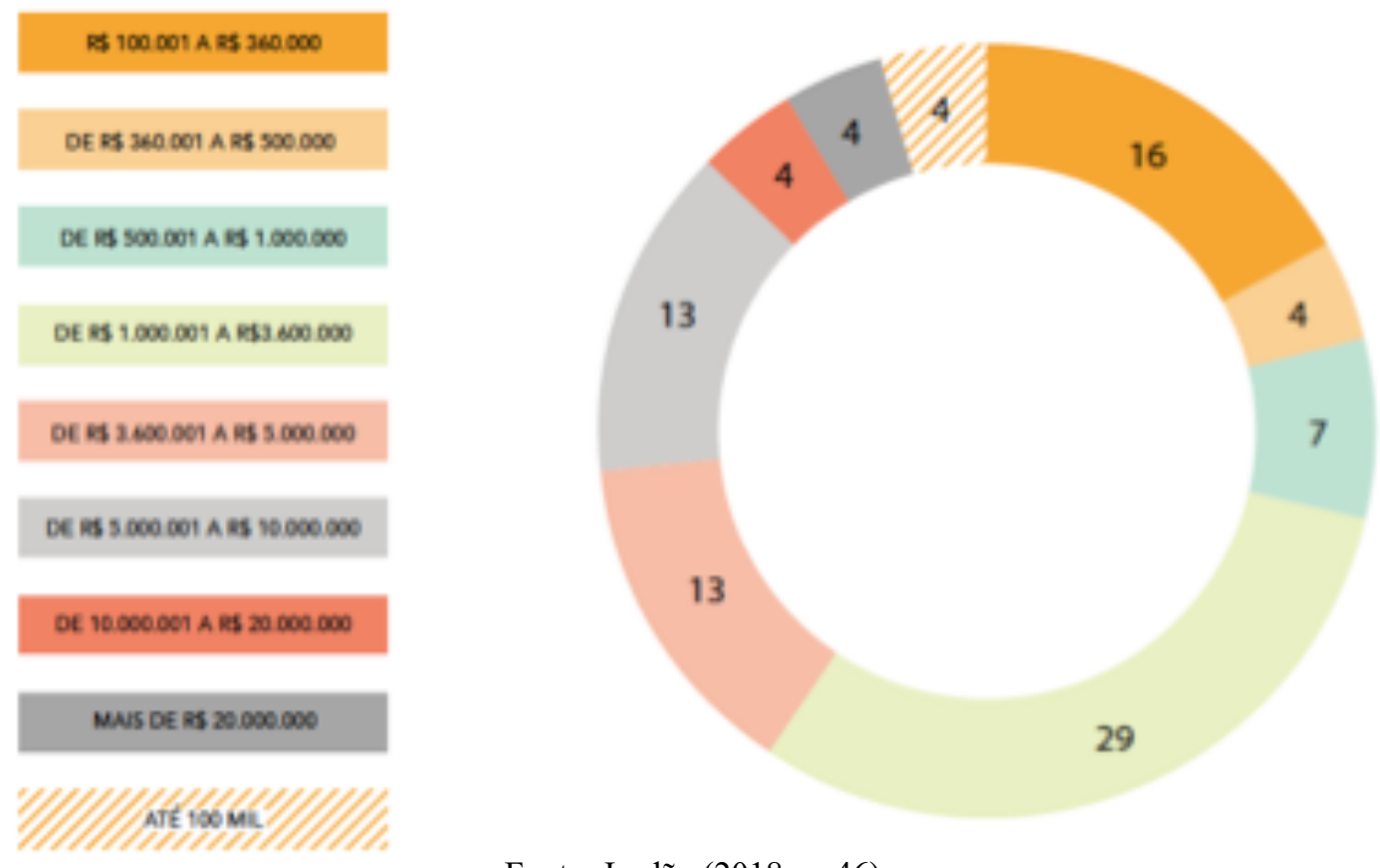

Fonte: Jordão (2018, p. 46).

Uma vez comparada a trajetória dos artistas à ideia de 'marca', observamos que o modo de produção de alguns artistas se assemelha ao de indústrias que produzem e comercializam bens duráveis. Tal como demonstrado na Figura 8 , o mercado de arte também é dividido em diferentes setores com distintas faixas de preço, podendo atender às mais diversas demandas. A maneira que os valores comerciais e a recepção dos outros agentes ocorrem segue a repetição de padrões, formas, temáticas que favorecem a manutenção do circuito de arte estabelecido, segundo Lipovetsky (2014, p. 45),

As empresas têm de atrair os talentos e estimular a inovação, mas, ao mesmo tempo, a fim de diminuir os riscos, elas se empenham em frear as criações audaciosas, em reproduzir as fórmulas que "dão certo" mais facilmente. As lógicas financeiras e organizacionais podem assim vir a contrariar a criatividade que devem, por outro lado, imperativamente favorecer: essa é uma das contradições do sistema que faz que as empresas do capitalismo artista possam apresentar graus de criatividade bem diferentes, conforme seu modo de organização e o momento.

Lipovetsky (2014) se refere a empresas que são ativas no setor criativo, podendo se aplicar essa ideia ao artista, tendo por parâmetro a ótica empresarial. Quando aproximada ao 
conceito de 'marca', a visão empresarial da carreira do artista influencia também no valor comercial, e é possível considerar que essa perspectiva auxilia no maior controle da variação desse valor.

\section{I.4.2 Euphrosyne ou Valor Social}

O valor social das obras, segundo Findlay (2012), está baseado na difusão das obras pelos agentes intermediários do mercado de arte, tais como curadores, críticos, mídia especializada, galeristas, colecionadores etc. Tal valor não pode ser medido em números como o valor comercial, mas é perceptível a sua influência nas vendas das obras, posto que se baseia, principalmente, no gosto pessoal e social.

Esse valor se baseia, principalmente, no gosto da época em que a obra se encontra e também nas temáticas exploradas no período pela crítica e história da arte. É possível estabelecer que esse valor se associa aos temas e artistas que estão na moda durante um certo período de tempo, atraindo a atenção dos agentes especializados e também de consumidores externos, tendo sua difusão presente para além dos meios focados em arte, como também nos jornais e revistas de grande de circulação.

O gosto, quando pensado para o consumo de obras de arte, deve ser considerado pelas noções de consumo como forma de experiência identitária. Segundo Lipovetsky (2014, p. 31), “o consumo com componente estético adquiriu uma relevância tal que constitui um vetor importante para a afirmação identitária dos indivíduos”. Ou seja, há uma aproximação da obra de arte à identidade dos seus consumidores, e não está limitada a um item de luxo a ser consumido por pessoas especializadas. Nessa lógica, a obra de arte se torna parte de um mundo estético que gera valores comerciais às experiências estéticas dos consumidores, seja mediante o consumo das obras por meio de exposições, ou até mesmo por aproximações com os artistas.

A aproximação do gosto com o valor social das obras permite que a análise se volte ao conceito de co-branding: as associações que os artistas fazem com galerias, curadores, críticos e outros agentes do circuito das artes demonstra que eles, em conjunto com o branding do artista, formam o mercado da arte, ou art machine como definem Rodner e Thomson (2013). Esses agentes são responsáveis pela criação do gosto e dos desejos dos consumidores de arte, escolhendo a quem cada produto deve ser exibido. 
O valor social, segundo Findlay (2012), fica refém do capitalismo artista proposto por Lipovetsky (2014, p. 51), que "é esse sistema no qual indústria e arte, mercado e criação, utilidade e moda, marca e estilo não estão mais disjuntos". O capitalismo artista não é, então, "designado como tal em razão da qualidade estética das suas realizações, mas dos processos e das estratégias que emprega de maneira estrutural visando à conquista dos mercados" (LIPOVETSKY, 2014, p. 42).

As obras a serem comercializadas, portanto, não estão restritas ao campo de mercadoria, mas devem ser consideradas também por outros aspectos, como estilo, elegância, beleza, emoções, imaginário, personalidade, o que Lipovetsky (2014) denomina por capitalismo transestético.

\section{I.4.3 Aglaea ou Valor essencial}

O valor essencial é o mais subjetivo, considerando que ele abrange os conceitos intrínsecos da obra, que independem da opinião dos agentes do mercado da arte, mas se agrega diretamente a como a obra atinge cada indivíduo.

Nesse sentido, Danto (2006) propõe uma discussão referente ao entendimento da arte contemporânea, considerando a evolução de uma arte puramente voltada para sua materialidade e tecnicidade, para uma arte que se coloca no âmbito da filosofia da arte, a partir de noções hegelianas, sendo que

(...) o que agora é estimulado em nós por obras de arte não é apenas a satisfação imediata, mas também nosso julgamento, uma vez que submetemos à nossa consideração intelectual o conteúdo da arte, e os meios de apresentação da obra de arte, e a adequação ou inadequação de um ao outro. A filosofia da arte é, por essa razão, uma necessidade maior em nossos dias do que fora nos dias em que a arte por si só produzia uma completa satisfação. A arte nos convida a uma consideração intelectual, e isso não com a finalidade de criar arte novamente, mas para conhecer filosoficamente o que arte é (HEGEL,1828, apud DANTO, 2006, p. 150).

Para Danto (2006, p. 150), “a passagem da arte pré-modernista para a modernista, se concordarmos com Greenberg, é a passagem das características miméticas para as não miméticas na pintura", referindo-se à evolução da figuração para a abstração. Para esse autor, no momento que a arte deixa de possuir elementos figurativos, saindo da mimese, é o princípio do fim da arte pela arte, ou seja, arte que se justifica pelo seu suporte, é uma arte sem estilo ou movimento. 
O final do modernismo, ainda segundo Danto (2006), ocorre quando o questionamento acerca da obra artística considera: por que isso é uma obra de arte? Com esse questionamento, a arte se coloca a serviço de questões pessoais e políticas dos artistas, não mais restrita aos limites de suportes utilizados. A perspectiva desse autor nos permite entender como o valor essencial é criado quando pensado na arte contemporânea: para além do seu suporte, o valor essencial está ligado à filosofia da arte e aos julgamentos internos de cada indivíduo.

Findlay (2012) aponta, ainda, a importância desse valor no entendimento das novas formas de arte que surgem no decorrer da história da arte, pois este se atualiza em harmonia com a sociedade, seus questionamentos e posicionamentos. O autor cita uma frase de Michael Govan, atual diretor do Los Angeles Country Museum of Art (LACMA): "a arte não perde seu valor emocional ou artístico (...) isso não muda, não importa a economia" (FINDLAY, 2012, p. 90, tradução nossa $)^{10}$.

Além disso, a proposição e a maneira de apreciar a obra de arte pode mudar e Danto (2006) demonstrou isso ao analisar filosoficamente a arte contemporânea; no entanto, o seu valor essencial pode permanecer intacto.

No capítulo II apresentado a seguir, exploraremos a aplicação do branding nos processos de legitimação dos artistas contemporâneos, considerando as noções de valores das obras de arte levantadas nesse capítulo.

\footnotetext{
${ }^{10}$ Tradução livre de: "art doesn't lose its emotional or artistic value (...) that doesn't change no matter what the economy" (FINDLAY, 2012, p. 90).
} 


\section{Capítulo II: Processos de legitimação e aplicação do branding na trajetória de artistas contemporâneos}

No capítulo anterior, abordamos algumas noções sobre o mercado de arte e, também, as divisões dos valores das obras de arte em três etapas: o comercial, o social e o essencial (FINDLAY, 2012). O mercado de arte contemporâneo teve que sofrer adequações para a inserção das novas linguagens desenvolvidas pelos artistas e pelos novos entendimentos acerca do que é arte. O mercado de arte e os processos de legitimação da produção artística caminham lado a lado para que o sistema das artes seja fomentado e esteja sempre aquecido.

É necessário ressaltar que as obras contemporâneas, segundo Cauquelin (2005) estão ligadas a um regime de comunicação e não apenas a um regime do consumo, como essa autora entende a arte moderna. O regime de comunicação engloba os três estágios do sistema de consumo, sendo estes: produção, distribuição e consumo. No entanto, não se restringem a uma linearidade, por ocorrerem em rede. São esses três estágios que formam o sistema de vendas de bens simbólicos da arte contemporânea. Os agentes não permanecem em apenas uma das categorias, mas se misturam e podem atuar nos três estágios, sendo esta uma das características principais do mercado de arte contemporânea.

Esse esquema [produção - distribuição - consumo] diz respeito não somente aos bens materiais, mas também aos bens simbólicos. Produtores: os fornecedores de matérias-primas, os industriais (grandes e pequenos), mas também os educadores, os intelectuais (científicos ou literários), os artistas. Distribuidores: os comerciantes, negociantes, marchands. Consumidores: todo o mundo. Sem exceção - pois mesmo o pobre, até o miserável consome alguma coisa. Em um sistema como esse as posições são claras e bem definidas, e se nem todos encontram seu lugar, ao menos os que encontram estão bem 'encaixados'. É ainda necessário que esse equilíbrio possa ser mantido. Para isso, o consumo dos bens deve no mínimo engolir a produção e, melhor ainda, devolvê-la. Nada de tempo morto. É a velocidade contínua, sem interrupção desastrosa para o equilíbrio do conjunto que é, aqui, a lei. Nos dois extremos da cadeia, produção e consumo lançam-se um desafio permanente. Eles são necessários um ao outro, pois, na qualidade de peça da mecânica, o consumidor é pelo menos tão necessário quanto o produtor; é um cliente, um membro da família, quer esteja atualmente consumindo, quer seja apenas virtual (CAUQUELIN, 2005, p. 31).

A principal diferença do regime de comunicação é que cada agente pode atuar nos diferentes estágios, não sendo obrigatórias que as posições sejam fechadas e estejam estabelecidas. Ao definir o mundo da arte em um sistema de rede que segue o regime da 
comunicação, Cauquelin (2005) possibilita um entendimento do mercado de arte que abarca todas as etapas desse sistema, propondo circularidades no esquema linear de produçãodistribuição-consumo, utilizado no regime de consumo da arte moderna. O consumidor torna-se produtor de demanda, fomentada pelos intermediários da distribuição, mas também o produtor pode ser o agente de distribuição, entre outras possibilidades para que os agentes atuem dentro dessa rede (CAUQUELIN, 2005). Esse sistema, então, possui proximidades claras com qualquer outro mercado de bens simbólicos e, seguindo essa lógica, Pinho (1988) cria um diagrama de funcionamento do marketing da pintura, podendo ser aplicado para todas as linguagens da arte contemporânea, conforme apresentado na Figura 9 a seguir.

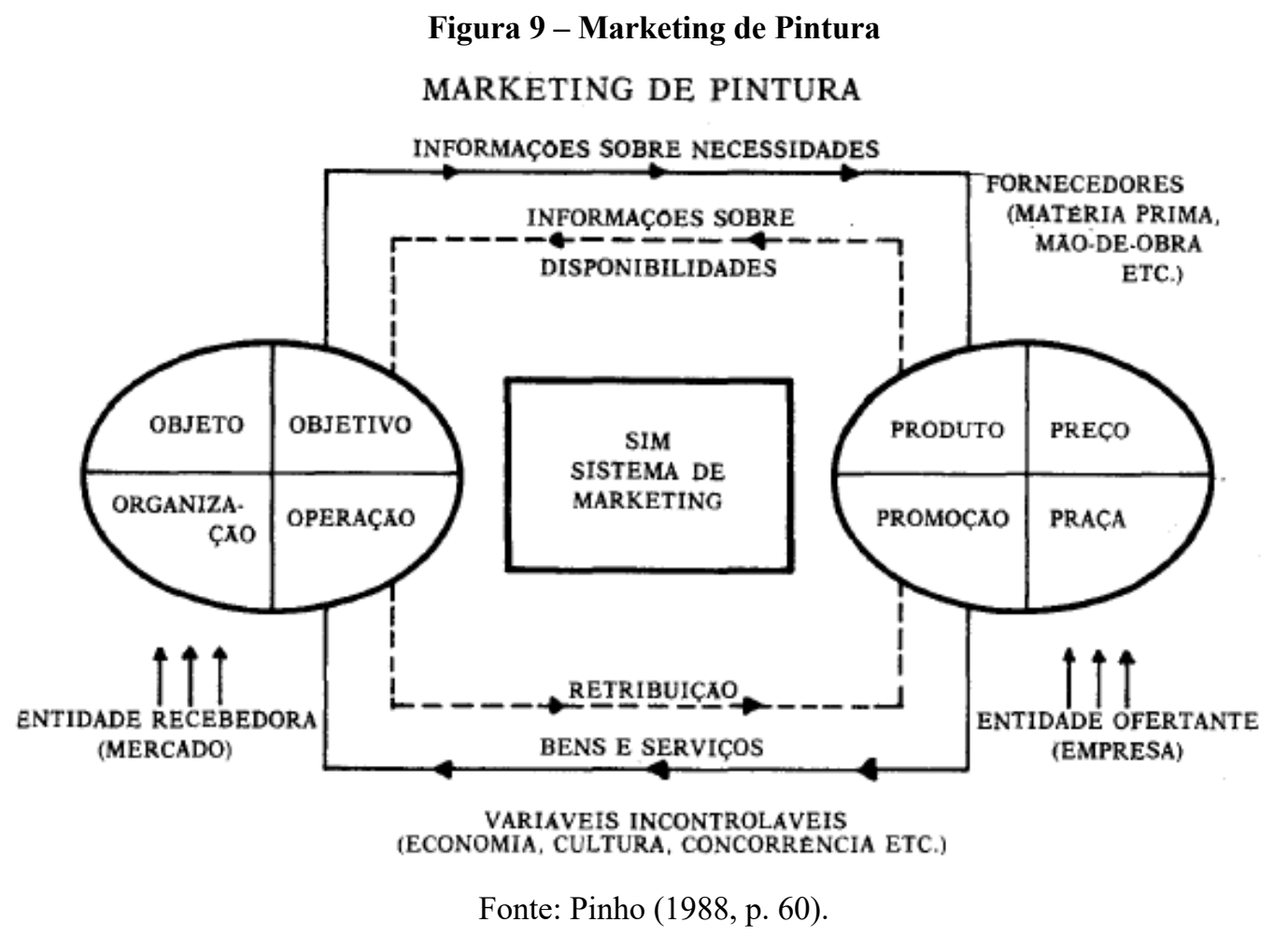

Tanto Cauquelin (2005) quanto Pinho (1988) visualizam o sistema da arte como não linear, mas com os mais diversos caminhos nos quais os agentes podem atuar em todas as etapas, não deixando as suas funções determinadas de maneira definitiva dentro do sistema. A noção de rede proposta pelas autoras coaduna-se com a ideia de uma rede horizontal, na qual a hierarquia e o centro da rede podem ser modificados, de acordo com o momento em que se encontram, como indica Rubim (2005).

A horizontalidade contrapõe-se às estruturas hierarquizadas. A ausência de um centro ordenador, que por determinação prévia concentre as decisões e responsabilidades da rede, estimula o pluralismo de ideias e ações, distribui equitativamente direitos e deveres, desburocratiza as atividades, permite 
trocas diretas entre os membros e reforça o projeto coletivo instaurador da rede. As eventuais centralidades, que seguem a lógica do envolvimento e do reconhecimento, emergem durante processos e atividades, e serão substituídas por outras, na medida em que diminua a sua capacidade de resposta. Assim, cada elemento da rede pode ser um centro, dependendo do momento e do ponto de vista (RUBIM, 2005, p. 28).

Então, ao aproximarmos os conceitos de Pinho (1988), Cauquelin (2005) e Rubim (2005), a rede do sistema da arte pode ser entendida como horizontal, sem estruturas hierarquizadas e com a possibilidade de os agentes atuarem em todos os âmbitos, tornandoos centro da rede, de acordo com o ponto de vista, permitindo ser analisada em todos os momentos em que ela ocorre e as possíveis atuações de todos os agentes participantes.

O mercado de pintura abordado por Pinho (1988), por exemplo, permite entender de que maneira os agentes atuam dentro da entidade recebedora denominada por mercado de arte, considerando que essa entidade recebe os bens e serviços tanto dos produtores, quanto dos distribuidores e consumidores: o mercado devolve aos agentes as informações acerca da demanda e das suas necessidades, cabendo aos agentes a devolutiva de todas as informações e disponibilidades quanto aos bens e serviços. Pinho (1988) frisa a aproximação desse sistema de artes com um sistema de inteligência de marketing (SIM), que permite melhor gerenciamento de todos os stakeholders:

O marketing da pintura possibilita, entre outros, o conhecimento: do que os consumidores desejam comprar, suas necessidades, status social, recursos disponíveis, etc.; das respostas dos compradores (reais ou potenciais) aos estímulos do mercado; da influência da cultura, tradição, meio social, competição social, preferências de grupos ou segmentos sociais, etc.; das expectativas dos consumidores em relação ao comportamento dos preços e às possibilidades de vendas futuras (PINHO, 1988, p. 72).

Na Figura 9 é possível perceber a presença dos mercados primário e secundário, sendo que o primeiro atua como entidade recebedora para a primeira venda das obras e o segundo como entidade recebedora para a revenda. Cada um desses mercados pode ser considerado ramificações do mercado de arte em rede, possuindo características próprias e atendendo às necessidades específicas, mesmo que o público final muitas vezes transite entre os dois âmbitos. Vale ressaltarmos que apesar dessa ramificação de mercados, ambos os mercados agem de maneira a fomentar a produção, distribuição e consumo das obras de arte, tornando-os agentes também responsáveis pelo processo de legitimação dos artistas contemporâneos. 
O mercado primário pode ser explicado pela representação de artistas e a primeira venda de suas obras, como já abordamos, participando muitas vezes da introdução dos artistas no mercado de arte. É responsável pela inclusão dos artistas nas principais exposições, por colocá-los em pauta para a crítica e teoria da arte e, também, inicia o diálogo com colecionadores para investirem na criação de valores para essa produção. Considerando a Figura 9, é possível colocar o mercado primário como o intermediário entre o consumidor e a entidade ofertante (nesse caso, o artista), no qual o mercado assimila as produções artísticas e as disponibiliza aos consumidores e artista em termos de distribuição dos produtos (obras) e informação sobre suas disponibilidades e condições para aquisição e/ou apreciação.

Por lançar novos nomes no mercado, o mercado primário assume riscos caso a resposta do público (tanto real quanto potencial) não seja positiva. Para tanto, esse segmento de mercado precisa de um maior entendimento de seu público-alvo, considerando seus gostos e procuras na hora de investir em arte, para que seja possível esse processo de introdução do artista no mercado. Os artistas que possuem um saldo positivo no mercado primário tendem a adquirir consciência da sua atuação dentro dele e ajudam também a criar estratégias para e com outros agentes legitimadores para que sua obra não corra risco de cair em esquecimento.

O mercado secundário, no entanto, tarda em assimilar artistas contemporâneos por conta do distanciamento histórico, que não os legitima com rapidez, para a revenda das obras. Atualmente esse mercado tem uma grande concentração de obras modernas e antigas: produções que já possuem apreciação, preço e tradição e estão no repertório cultural dos consumidores desse segmento.

\section{II.1 Branding, Co-Branding e Brand Equity}

A análise de rede do sistema de arte, em conjunto do mercado da pintura e do regime de comunicação, nos permite aproximações dos artistas aos conceitos de branding, uma vez que os consumidores das obras auxiliam na construção dos valores sociais e constroem uma narrativa de branding, a partir de uma cultura de marcas (PREECE; KERRIGAN, 2015). A cultura das marcas é naturalizada pelos consumidores, nos remetendo às teorias de 
Lipovetsky (2014) sobre o capitalismo artista, no qual o consumidor se torna um indivíduo que baseia sua maneira de consumir em reflexos de sua identidade, tornando o capitalismo artista, então, "a formação que liga o econômico à sensibilidade e ao imaginário; ele se baseia na interconexão do cálculo e do intuitivo, do racional e do emocional, do financeiro e do artístico" (LIPOVETSKY, 2014, p. 43). São esses desejos de um consumo identitário que, com os demais agentes do sistema da arte, auxiliam na criação de um sistema de marketing das obras, permitindo a maneira de consumir seja prevista e a experiência que o consumidor visa seja atingida.

O fato de os artistas tornarem-se pelas negociações e de muitos dos riscos, dentro de práticas de marketing empreendedores e responsáveis, é reconhecido por outros autores, tais como Fillis (2000), Norris e Fine (2014), Schroeder (2005) e Robertson (2005), tendo em comum entre eles as aproximações do artista empreendedor, entendido pelo público a partir do viés da criatividade, e o afastando da perspectiva meramente econômica e administrativa de gerir uma empresa.

O capitalismo artista contribui para que o público entenda os artistas pela ótica da criatividade e não da gestão tradicional de empresas; o artista se encontra entre o racional e o emocional, entre o fazer artístico e a atuação mercadológica; seu produto principal é o seu fazer artístico, suas obras, mas, para os consumidores, sua imagem, sua atuação social, também são fatores a serem consumidos, uma vez que auxiliam na criação da experiência total da produção artística, pois "a prioridade não se volta apenas para a fabricação material dos produtos, mas também para a criação de imagens, de espetáculos, de lazeres, de roteiros comerciais que possibilitam a distração e experiências excitantes" (LIPOVETSKY, 2014, p. 65). Essa junção da produção das obras, criação de uma imagem e de uma experiência pode ser reconhecida como o branding dentro da concepção do artista como uma marca.

Preece e Kerrick (2015) dividem a teoria do branding em duas linhas de pensamento: uma é a gestão estratégica da marca, a enfatizar o controle da organização e, também, as visões socioculturais das marcas, que consideram marcas como um advento construído socialmente com uma gama de atores que, de maneira coletiva, criam a identidade da marca. Essa visão sociocultural do branding liga-se a outros conceitos do marketing como o brand equity e também o co-branding, ambos os termos a serem explorados neste capítulo.

A teoria do branding nos permite descomprimir as relações entre os artistas e os produtos que eles criam, para entender a maneira complexa pela qual o valor emerge no mercado de arte. A chave para isso é que o valor e a integridade do produto estão, inextricavelmente, ligados ao valor e à 
integridade do próprio artista e são comercializados como tal. Com foco na arte visual, descobrimos que o produto é comercializado como a personificação do artista. No entanto, argumentamos que esse foco não representa a realidade da composição da marca artística, que é de fato criada e desenvolvida através da ação coletiva de várias figuras-chave do mundo das artes em colaboração com os artistas. Seguindo o apelo de Mele, Pels e Storbacka (2014) para 'analisar quais ações são realizadas (...) antes, depois e às vezes ao invés do intercâmbio monetário' para entender o valor, então nos afastamos da análise de nível individual de artistas marca, para se concentrar em como os artistas operam como um coletivo para construir capital social e cultural. Argumentamos que este estudo tem implicações mais amplas, já que muitas indústrias, incluindo outras indústrias criativas e de alta tecnologia, contam com líderes de marca cujas marcas pessoais estão inextricavelmente ligadas aos produtos que produzem e cujos produtos dependem da ação coletiva para se tornarem legitimados (PREECE; KERRIGAN, 2015, p. 1.208, tradução nossa). ${ }^{11}$

O valor proposto por Preece e Kerrigan (2015) é o valor da marca do artista, ou seja, o brand equity do artista: diferentemente das noções de valores propostas por Findlay (2012) no capítulo anterior, nas quais analisava a criação de valor das obras dos artistas de maneira a analisar como cada obra dentro de uma produção poderia ter diferentes impactos e valores, demonstra que a carreira dos artistas contemporâneos como um todo está diretamente ligada aos outros agentes que auxiliam na criação desses valores. Relembrando as definições de Aaker (1992), trazidas no capítulo anterior, o brand equity engloba cinco parâmetros de medição, a saber: lealdade da marca, reconhecimento do nome da marca, associações da marca percebidas pela qualidade oferecida e, por último, outros ativos da marca, como patentes, canais de relacionamento, entre outros. Esses parâmetros são medidos a partir da interação da marca com o público consumidor e seu mercado, não sendo apenas traduzido em números, mas também em análises acerca da marca. Quando pensado o brand equity para as marcas dos artistas temos que, para além de analisar seus produtos (no caso,

\footnotetext{
${ }^{11}$ Tradução livre de: Branding theory allows us to unpack relationships between artists and the products they create to understand the complex way through which value emerges in the art market. Key to this is that the value and integrity of the product is inextricably linked to the value and integrity of the artist themself and marketed as such. Focusing on visual art, we find that the product is marketed as the embodiment of the artist. However, we argue that this focus does not represent the reality of the composition of the artistic brand, which is in fact created and developed through the collective action of a number of key artworld figures in collaboration with the artists. Following the call from Mele, Pels, and Storbacka (2014) to 'analyse what actions are carried out (...) before, after and sometimes instead of the monetary exchange' to understand value, we therefore move away from individual level analysis of branded artists to focus instead on how artists operate as a collective to build social and cultural capital. We argue that this study has wider implications as many industries, including other creative and high-tech industries, rely on figurehead branded leaders whose personal brand is inextricably linked to the products that they produce and whose products rely on collective action to become legitimized (PREECE; KERRIGAN, 2015, p. 1.208).
} 
as obras), o brand equity associa-se também à marca do artista como figura pública e social. Na Figura 1 disponível no capítulo anterior é possível perceber os componentes que formam a marca dos artistas dentro do sistema da arte e que, em conjunto, criam o branding dos artistas.

Tal como considerado por Preece e Kerrigan (2015), o brand equity dos artistas é o brand equity de sua marca, considerando todas as suas atuações no sistema e também fora dele. As posições políticas, as participações em eventos, seu contato com a população mais vulnerável e suas colocações nas redes sociais são aspectos que fazem parte do brand equity dos artistas, fato que reflete na sua marca e também no valor de suas obras. Findlay (2012) assume o valor social como importante para que a obra seja difundida perante a rede do sistema da arte, sendo este criado pelos críticos, curadores, historiadores, entre outros que auxiliam na criação de uma narrativa para as obras. Quando avaliada na ótica do brand equity dos artistas é possível notar que a visão desses agentes é influenciada pela atuação do artista como figura pública, podendo suas opiniões e participações contribuir para uma determinada imagem por parte dos agentes. Os valores propostos por Findlay (2012), então, juntam-se ao brand equity para formar a opinião pública acerca dos artistas, permitindo que esta seja traduzida para o grande público com o viés proposto por esse processo de branding.

Considerando os parâmetros de brand equity de Aaker (1992), percebemos que, quando estes são pensados para os artistas-marca, estes sofrem adaptações ligadas ao sistema das artes. A lealdade à marca, o reconhecimento do nome, dá-se a partir da participação dos artistas em eventos, coleções, posicionamentos e também pelas suas participações em redes sociais. Os ativos dos artista-marcas relacionam-se às exposições, às coleções em que constem as obras, entre outros, associando à ideia de valor social das obras de Findlay (2012). Esses parâmetros podem acarretar mudanças no valor de marca do artista, de acordo com as decisões tomadas por ele próprio em relação às suas posições e participações no mercado, e também aos agentes do sistema, que podem considerá-las positivas ou negativas para o brand equity.

Para além de entender o funcionamento das marcas de maneira empresarial, o branding permite então analisar a atuação da marca dentro do sistema em rede que possui diferentes agentes para que ocorra o funcionamento e legitimação dos artistas.

A legitimação ocorre quando o não aceito é aceito por consenso. Esse consenso nunca será absoluto, pois nunca há um consenso completo dentro de uma sociedade sobre qualquer coisa. Por esta razão, o consenso precisa ser definido minimamente - é específico do assunto, o quase consenso conta 
como consenso, e só precisa existir no nível coletivo e não necessariamente no nível individual (ZELDITCH, 2001, in BAUMANN, 2007, p. 35, tradução nossa). ${ }^{12}$

Nesse sentido, o processo de legitimação dos artistas contemporâneos ocorre tanto no mercado primário quanto no secundário. Esse processo de "aceitar o não aceito por consenso" é realizado por um conjunto de agentes do sistema e depende do contexto em que ocorre, podendo ser nos níveis regional, nacional e internacional. A dependência de outros agentes pode se enquadrar no conceito do marketing de co-branding, no qual associações de marcas tornam-se elementos chave para a valoração de cada uma das marcas envolvidas (brand equity).

O co-branding representa uma estratégia de aliança de marca no longo prazo na qual um produto é marcado e identificado simultaneamente por duas marcas. De acordo com essa definição, as seguintes características constituem produtos co-branded: Primeiro, as marcas participantes devem ser independentes antes, durante e após a oferta do produto co-branded (Ohlwein e Schiele, 1994). Em segundo lugar, as empresas proprietárias das marcas devem implementar uma estratégia de co-branding de propósito (Blackett e Russell, 1999). Terceiro, a cooperação entre as duas marcas deve ser visível para os potenciais compradores (Rao, 1997) e, quarto, um produto deve ser combinado com as duas outras marcas ao mesmo tempo (Hillyer e Tikoo, 1995; Levin et al., 1996) (HELMER, HUBER et al., p. 360, tradução nossa). ${ }^{13}$

Da mesma forma que o branding é um reflexo da carreira do artista, o co-branding é utilizado para refletir de maneira positiva as associações com outras marcas. O co-branding no sistema de arte entende que os agentes também podem ser vistos a partir do branding, e que as associações podem ser benéficas para todas as partes envolvidas. No caso dos artistas contemporâneos, essas associações ocorrem com críticos de arte, curadores, galerias, espaços independentes, instituições públicas ou privadas, entre outros. A presença da obra do artista em determinado contexto pode refletir o ponto de vista artístico e político do

\footnotetext{
${ }^{12}$ Tradução livre de: Legitimation occurs when the unaccepted is made accepted through consensus. This consensus will never be absolute, as there is never complete consensus within a society about anything. For this reason, consensus needs to be defined minimally-it is issue specific, nearconsensus counts as consensus, and it need only exist at the collective level and not necessarily at the individual level (ZELDITCH, 2001, in BAUMANN, 2007, p. 35).

${ }^{13}$ Tradução livre de: Co-branding represents a long-term brand alliance strategy in which one product is branded and identified simultaneously by two brands. According to this definition, the following characteristics constitute co-branded products: First, the participating brands should be independent before, during, and after the offering of the co-branded product (Ohlwein and Schiele (1994)). Second, the companies that own the brands should implement a co-branding strategy on purpose (Blackett and Russell (1999)). Third, the cooperation between the two brands must be visible to potential buyers (Rao (1997)), and fourth, one product must be combined with the two other brands at the same time (Hillyer and Tikoo (1995); Levin et al. (1996)) (HELMER et al., p. 360).
} 
ambiente em que se encontra, o gosto de quem a possui e a linha de pesquisa do crítico; portanto, as associações no sistema da arte são importantes para que o artista seja legitimado no sistema, ocorrendo das mais diversas maneiras. O co-branding, tal como definido acima, é a associação entre duas marcas que ocorre de maneira independente, ou seja, uma marca existe independentemente da outra, mas, quando passam a atuar juntas, essa associação torna-se positiva para ambas. No caso dos artistas é possível entender que tanto os artistas quanto os outros agentes atuam de maneira independente, podendo coexistir dentro do sistema sem afetar diretamente as suas marcas, mas quando fazem parcerias e associações, estas são favoráveis para ambos os lados.

As associações realizadas pelo co-branding aproximam-se à noção de redes já abordada neste capítulo, que não é hierarquizada e deve ser compreendida como horizontal. Castells (1996, p. 605) entende que "as redes constituem a nova morfologia das sociedades e a difusão da sua lógica modifica as operações e os resultados dos processos de produção, experiência, poder e cultura". Tanto para o sistema de arte, quanto também para o mercado de arte, a presença das redes torna o regime de comunicação proposto por Cauquelin (2005) funcional a partir dessas associações, que destacamos como co-branding. Sem essas associações, a rede perde seu principal objetivo de intercâmbio e de cooperação entre as partes. O sistema da arte em rede constitui, assim, uma maneira de legitimação dos artistas contemporâneos a partir também de redes, alterando, tal como previsto por Castells (1996), as noções de produção e de experiência das obras.

Para o entendimento das associações e do processo de legitimação dos artistas, será analisado a seguir o ecossistema da arte de Hargreaves McIntyre (2004), criado a partir de estudos preliminares do mercado de arte britânico para o entendimento e análise da legitimação dos artistas.

\section{II.2 O Ecossistema do Mercado de Arte}

Morris Hargreaves McIntyre propôs, em 2004, um estudo chamado Taste Buds how to cultivate the art market para definir maneiras de cultivar e ampliar o mercado de arte contemporâneo britânico, que se resume em três questionamentos:

1. Como aumentar e melhorar as vendas de arte contemporânea inovadora e também de comissões privadas a partir de diversos pontos de distribuição? 
2. Como ajudar artistas a se tornarem mais empreendedores no seu engajamento com o mercado de arte?

3. Como aumentar o público para a arte contemporânea?

Para o nosso propósito, o segundo questionamento desse estudo é importante, pois visa a entender estratégias para engajar artistas no mercado de arte de maneira empreendedora. Vale ressaltar que o estudo foi realizado no contexto da Inglaterra, país que lidera o conceito de Indústrias Criativas, onde esse tipo de comportamento provindo dos artistas já está absorvido e vem sendo aplicado, no entanto, ainda se encontra em disseminação em outros locais.

Os estudos de Hargreaves McIntyre (2004) consideram três etapas: produção, fornecedores e demanda. Similar às proposições de Pinho (1988) e de Cauquelin (2005), o pesquisador associa as etapas de marketing e de redes, às produções artísticas, ou seja, estas não se isolam das ideias de mercado aplicadas para outros tipos de produtos que também podem ser consumidos/ adquiridos. Em termos de produção foram analisados o que motiva os artistas a produzirem suas obras, de que maneira os artistas veem o mercado de arte e como eles se orientam nesse mercado. Nessa etapa já é possível visualizar o perfil empreendedor dos artistas e suas potencialidades, de acordo com o posicionamento que tomam perante o mercado. Em relação aos fornecedores foi avaliado como é realizada a distribuição da produção artística, como o setor está estruturado e como satisfaz as necessidades dos artistas e seus compradores. Por fim, a etapa de demanda considera o porquê as pessoas compram arte e quais tipos de produtos artísticos se interessam em adquirir, visando a mensurar e entender a demanda existente para a arte contemporânea e o tamanho do mercado inglês. Hargreaves McIntyre (2004) considera que os artistas podem ou não ser atuantes nas três etapas, destacando que as associações com outros agentes são importantes para que estas etapas ocorram de maneira eficiente.

Para entender quem determina as trajetórias dos artistas e quais os possíveis caminhos para a legitimação, Hargreaves McIntyre (2004) criou um modelo de ecossistema para a arte, que engloba o setor público e privado do mercado de arte, indo desde a etapa de formação universitário e/ou empírica dos artistas até a sua legitimação. A partir de um diagrama cíclico e suscetível ao contexto em que o artista está inserido, deixa clara a necessidade de um perfil empreendedor para que a legitimação ocorra de maneira a atingir uma gama maior de consumidores. O formato cíclico do ecossistema da arte e de possível 
participação em todas as etapas se aproxima das ideias de Cauquelin (2005) de um regime de comunicação em rede, ressaltando que não há hierarquias dentro desse ecossistema.

Figura 10 - O ecossistema da arte

Modelo de Ecossistema da Arte

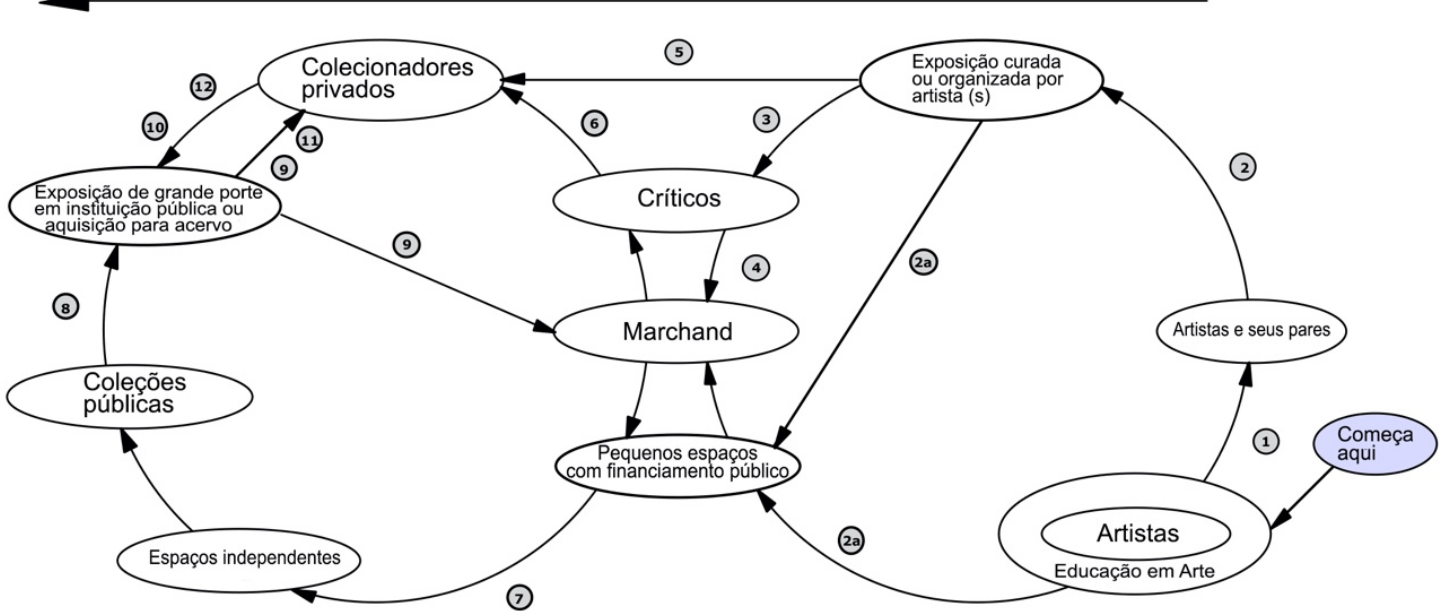

(1) Artistas atraem reconhecimento dos pares

(2) Exposição curada por artistas ou curadores independentes

(2a) Representação de uma galeria de pequeno porte

(3) Produção e atividade atrai a atenção da crítica

(4) Atrai atenção de galeristas e marchands

(5) Atrai atenção de colecionadores privados

(7) Galeristas endossam aval da crítica através de exposições/vendas em outras galerias ou espaços independentes de pequeno porte

(8) Compra ou exibição de obras em galerias de grande porte

(9) Legitimação aumenta o valor e o status do colecionador e também cria lucro para (9) galeristas e artista

(10) Colecionadores emprestam obras para coleções públicas

(11) Atuação dos colecionadores aumenta resultando em convites para participar em

(12) Colecionadores dispus

12. Colecionadores disputam as obras nas galerias

(6) Galeristas constroem a reputação do artista por meio de vendas, incluindo sua presença em feiras internacionais

Fonte: McIntyre, (2004, tradução nossa).

Como é possível perceber na Figura 10, no ecossistema das artes há doze etapas e uma ramificação para a legitimação dos artistas contemporâneos, sendo essas etapas não lineares e passíveis de vários caminhos. A metodologia de estruturação de ecossistema é usada principalmente quando se pensa inovação e empreendedorismo. Para Basole e Karla (2011), um ecossistema pode ser descrito como um sistema em rede que contém um conjunto de objetos que define como os atores que estão ligados uns aos outros, assumem lideranças de acordo com a etapa em que se encontram. No entanto, as lideranças sempre ocorrem de forma horizontal e sem hierarquias. Quando aplicada para o processo de legitimação de artistas contemporâneos, essa metodologia também pode ser usada para pensar em inovação e empreendedorismo no sistema de arte, colocando o artista como um agente que também divide responsabilidades para que essa legitimação ocorra. 
As doze etapas não possuem obrigatoriedade de ocorrer de acordo com a ordem numérica apresentada na Figura 10, porque podem variar no sentido horário ou anti-horário no círculo direito do ecossistema. No entanto, sempre se move de maneira crescente à esquerda, podendo estar sujeito a pular etapas e, até mesmo a estagnar em uma etapa específica. Nota-se que em todas as etapas ocorre a participação direta ou indireta do artista a partir de suas associações e de suas estratégias de difusão.

As etapas iniciais do processo de legitimação do artista (etapas 1 até 4) são as que criam o valor essencial e social de suas obras para que fomentem o valor comercial. Os valores de suas obras e de sua carreira caminham juntos para que o artista adquira seu lugar no mercado primário de arte nessas etapas iniciais, uma vez que são utilizadas para atrair a atenção de agentes que atuam em coleções de grande porte, sejam públicas ou privadas e também de galerias que possuam um grande raio de atuação. Essas etapas ocorrem normalmente no contexto local e regional e, caso passem para as etapas seguintes, podem atingir o contexto nacional e internacional. Nesse estágio inicial, o branding começa a se formar a partir das associações que o artista necessita fazer com os outros agentes para que ocorra visibilidade de sua produção (e de sua marca).

Essas etapas iniciais (etapas 1 a 4) ocorrem em diferentes momentos para cada artista, podendo incidir durante sua formação universitária e/ou empírica, depois de formados e, até mesmo em alguns casos, após muitos anos de produção contínua e anônima, pois há artistas sem formação acadêmica. Para que atraia a atenção dos pares, ou seja, dos agentes do circuito, existem diversas maneiras: através de open studios, cursos livres, aulas em universidades e escolas ou até mesmo pela difusão online de sua produção (McIntyre, 2004). Os agentes que têm o primeiro contato com os artistas se tornam os primeiros a realizar o co-branding, uma vez que difundem para outros agentes do mercado de arte e fazem esse ecossistema fluir. A legitimação começa nesse ponto, pois a produção passa a ser reconhecida e aceita por um grupo e, conforme avança no ecossistema, esse grupo aumenta e atinge outros setores do sistema.

As etapas iniciais da legitimação de um artista encontram-se no círculo do lado direito do ecossistema, pois não necessariamente a legitimação acarretará no segundo momento, sendo esse o círculo do lado esquerdo (etapas 5 a 12). Muitas vezes o sistema não absorve os artistas a ponto de transferi-los para as outras etapas, deixando-os estagnados no estágio inicial de legitimação. Vale notar que esse primeiro círculo é onde começa a ocorrer a criação do valor social e comercial das obras (no entanto, o comercial só é realmente 
estabelecido no segundo círculo graças às vendas para coleções privadas e públicas). Nesse estágio, o artista ainda não realiza vendas de suas obras por meio de galerias de grande porte que atingem as coleções, mas realiza as vendas em círculos fechados de frequentadores dos locais que expõe e também do público espontâneo que possa visitar os eventos. Essas primeiras vendas são o começo da concepção empreendedora do artista, uma vez que se faz necessário que ele participe das negociações, da precificação, embalagem, certificação e entrega de suas obras. É o momento em que o artista precisa entender qual o potencial de sua produção dentro do sistema, para que comece a atuar dentro da rede para além de, "apenas", produzir obras. Nessa etapa, também, os artistas utilizam editais públicos para promover suas exposições e aumentar o alcance de sua produção. Esses editais auxiliam o artista a demonstrar para o sistema o valor essencial de suas obras a partir de seus projetos, obras e exposições.

Nesse estágio, os críticos que estão em busca de novos artistas, se aproximam das produções e das atividades desenvolvidas por estes, com o intuito de introduzir ao sistema novos nomes e difundir suas obras e suas narrativas. A crítica contemporânea está diretamente ligada à imprensa, tal como notado por Hargreaves McIntyre (2004) em seus estudos, fato que auxilia que a produção artística se difunda de maneira mais eficiente, atraindo a atenção de outros agentes legitimadores. Essa associação com os críticos e, por consequência, com a imprensa, acarreta o início do processo de co-branding e da formação do valor da marca do artista (brand equity).

O círculo da esquerda, que engloba as etapas 5 até 12, apresenta os momentos da carreira do artista, na qual a legitimação está em processo avançado, quase em sua totalidade. Nesse círculo é possível perceber o artista já com relações e associações estabelecidas dentro do sistema e seu branding mais definido. Essas etapas dependem diretamente da visão empreendedora do artista, uma vez que as associações que fará podem acarretar a estagnação de sua carreira. Caso as associações se tornem conflitantes com o que é realizado pelo artista, o branding, sua marca pode ser prejudicada dentro do mercado. Na etapa 6 está prevista a criação da reputação dos artistas por meio das vendas, incluindo-os em feiras internacionais; passo que resulta no início da internacionalização da produção e, em consequência, do artista, permitindo que surjam parcerias e associações que impulsionem tanto a marca do artista quanto da galeria que o representa.

Nas etapas avançadas do processo de legitimação dos artistas (etapas 5 a 12), a participação dos colecionadores torna-se um elemento essencial para que a legitimação 
ocorra definitivamente. Tal como previsto na etapa 6, a reputação é criada por meio de vendas e os agentes responsáveis pelas compras são os colecionadores. Hargreaves McIntyre (2004) prevê que os colecionadores se tornam tão importantes quanto os galeristas e os críticos, uma vez que são os responsáveis por auxiliar na criação de demanda. Quando considerado o diagrama de Pinho (1988), apresentado na Figura 9, os colecionadores dão aos artistas as informações sobre as necessidades de consumo e de interesse que possuem, enquanto os artistas e as galerias que os representam devolvem a informação acerca das disponibilidades. Essa troca de informação desdobra-se em uma atuação em rede entre os colecionadores e o sistema, com a intenção de suprir as necessidades e criar novas demandas para esses artistas.

No momento em que o artista atinge a etapa 9 (Figura 10), as associações com as galerias, crítica, curadores e público estão formadas e tornam-se atos positivos de cobranding. A etapa 9 prevê, ainda, que a aquisição de obras do artista eleve o status dos colecionadores e também aumente o lucro para ambos - o artista e a galeria que o representa -, ou seja, nesse momento o seu branding já está estabelecido para o sistema e já é passivo de análises de brand equity da marca do artista.

A aplicação do ecossistema da arte para a análise do processo de legitimação dos artistas contemporâneos nos permite, então, que sejam separados por etapas os momentos chaves para que o processo ocorra, possibilitando o acompanhamento da carreira dos artistas e seja feito um alinhamento de quais estratégias podem ser utilizadas para inserção e estabilidade dentro do mercado de arte. Hargreaves McIntyre (2004) tinha o intuito de oferecer ferramentas aos artistas para que estes se tornem mais empreendedores e, por consequência, ampliem o público consumidor de arte contemporânea, considerando o contexto inglês em que se encontrava. A análise do ecossistema nos permitirá, em junção das noções de branding, co-branding e dos valores das obras de arte, entender as estratégias utilizadas pela artista Beatriz Milhazes, foco desta dissertação, em seus processos de legitimação e permanência no mercado de arte nacional e internacional. 


\section{Capítulo III: Beatriz Milhazes}

Tentei a princípio, mas depois parei. Eu disse a ele [Marcantonio Vilaça] que não conseguiria agir assim. Entendi logo que o ritmo do mercado não era para mim.

(Beatriz Milhazes, 2020, sobre o ritmo acelerado do mercado de arte contemporânea).

\section{III.1 Contexto sociohistórico da artista no início de sua carreira}

Nascida em 1960 na cidade do Rio de Janeiro, a trajetória de Beatriz Milhazes como artista tem início com a sua formação em artes plásticas na Escola de Artes Visuais do Parque Lage (EAV/ Parque Lage) entre 1980 e 1983. Anteriormente à sua formação no Parque Lage, a artista estudou Comunicação Social na FACHA, Rio de Janeiro, entre 1978 e 1981. Seu período de formação coincide com os últimos anos da ditatura militar no país, que acabou em 1985. Nesse momento ocorriam mudanças culturais e sociais no país, inclusive houve o afrouxamento da censura e do controle cultural por parte do governo ditatorial. No que se refere ao campo das artes visuais, nota-se avanços de artes com suportes tradicionais, que carregavam elementos históricos das décadas anteriores de maneira a repensá-los para esse momento. A década de 1980 é marcada, principalmente, pelo retorno da pintura, escultura e gravura. O crítico Frederico Morais (1991, p. 13) destaca que:

Os anos 80, no Brasil, foram marcados por uma forte e envolvente revitalização da pintura, que significou um reencontro do artista com a emoção e o prazer, após quase duas décadas de predomínio de uma arte fria e hermética (...) E, na medida em que não estão preocupados com o futuro, investem no presente, no prazer, nos materiais precários, realizam obras que não querem a eternidade dos museus nem a glória póstuma.

Essa ação de revitalização da pintura caminha em companhia dos debates de pósmodernidade levantados na época, os quais apontavam que a busca pelo novo e original se tornava obsoleta e pertencente ao período moderno. Essa arte da chamada "geração 80", termo usado para definir o grupo de artistas emergentes desse período, foi amplamente aceita pelo público, uma vez que, tal como nos aponta Morais (1991), rememorava a emoção e o prazer. A pintura, segundo Morais (1991, p. 221) "tornou-se o vale-tudo", no qual os artistas 
podiam não se comprometer com tendências, estilos ou temas. Morais (2001) entende que foi o fim das utopias sociais e a preocupação pragmática com o clima que pairava no tempo do governo ditatorial. Valorizar os prazeres seria, então, despolarizar os conceitos artísticos das obras.

Morais (1991) se debruçou no interesse dos artistas pela pintura nessa época, entendendo que a experimentação com os meios se oporia à arte conceitual realizada nos anos anteriores, temas que explorou em exposições com sua curadoria, tais como a mostra Pintura/Brasil, que ocorreu no Palácio das Artes em Belo Horizonte e também a mostra Pintura como Meio, ocorrida no Museu de Arte Contemporânea em São Paulo. Esse autor auxilia, então, ao direcionamento curatorial acerca do pensamento que culminaria na exposição Como vai você, Geração 80?, que ocorreu em 1984, na Escola de Artes Visuais do Parque Lage, no Rio de Janeiro, curada por Marcus de Lontra Costa, Paulo Roberto Leal e Sandra Magger. Nessa exposição participaram 123 artistas, incluindo Beatriz Milhazes, concentrando artistas do Rio de Janeiro e de São Paulo, em sua maioria estudantes de artes visuais do EAV Parque Lage e da Fundação Armando Álvares Penteado (FAAP-SP). Essa mostra, em especial, destacou artistas jovens e emergentes, e é um marco importante para a inserção desses artistas no sistema da arte desse período. A repercussão dessa mostra ocorreu em nível nacional e destacou o caráter experimental da mostra, ocupando espaços não convencionais de exposição de obras, tais como o cofre e os banheiros.

No caso brasileiro, se formos levar em conta a mostra que lançou oficialmente para o país essa nova geração de artistas - refiro-me à Exposição Como vai você, Geração 80?, realizada na Escola de Artes Visuais do Parque Lage no Rio de Janeiro em 1984 -, podemos observar que a esmagadora maioria dos artistas participantes - em torno de $120-$ gravitam entre as idades de 22 a 36 anos. Embora 120 artistas possam parecer um número exorbitante para um lançamento, na verdade, a quantidade de jovens artistas que tem se lançado no cenário da arte brasileira nos últimos anos é muito maior. Em São Paulo, a cada mês, no mínimo dez novos nomes são colocados em cena, através de exposições em galerias do circuito, entidades museológicas e centros culturais. Esta situação, aliada ao uso que a imprensa não especializada faz deste fenômeno, tem causado muitas vezes, na crítica e no público, uma sensação geral de perplexidade e descrédito em relação à produção desses jovens, impedindo uma análise mais acurada do fenômeno em si, e um aprofundamento maior sobre a produção de cada um desses artistas. (CHIARELLI, 2012, p. 12-13).

Herkenhoff (2007, p. 21), no entanto, quando analisa a produção de Milhazes dessa época entende que:

Por volta de 1984, o Brasil saia da ditadura anistiando o terrorismo de Estado, diferentemente da Argentina e do Chile, que fazem reflexão 
coletiva sobre seus regimes militares. A uma irresponsabilidade política diante do Estado de direito (rule of law) corresponderia uma pintura hedonista, sem projeto racional. Milhazes reage a isto. Com uma paleta rebaixada e econômica, a artista aponta para a malha geométrica. Seu espaço tem regras (rules), embora não fossem cânones.

A produção da artista nesse período ainda não havia se debruçado por completo em uma paleta de cores fortes e vibrantes, como viria a acontecer anos mais tarde, se atinha a cores sóbrias e a malha geométrica que acompanharia as pinturas da artista até os dias atuais. Essa racionalidade deve-se principalmente à sua formação na Escola de Artes Visuais do Parque Lage sob a orientação de Charles Watson, professor especializado em Processos Criativos / Problem Finding e Desempenho Otimizado, da Bath University na Inglaterra (CHARLES WATSON..., 2020). Herkenhoff (2007) ressalta a importância da orientação de Charles Watson nesse início de carreira de Milhazes, uma vez que trouxe para os seus alunos um ensino baseado na disciplina e no estímulo à invenção, método utilizado por Watson visando ao melhor desempenho no processo criativo dos artistas.

Quando consideramos os anos iniciais de formação de Beatriz Milhazes como artista, precisamos ter em mente que o começo dessa década de 1980, além de ser o período final da ditadura militar brasileira, ocorreu logo após o incêndio no Museu de Arte Moderna do Rio de Janeiro, ocorrido em 1978, o qual quase destruiu totalmente seu acervo e biblioteca, sendo este até então o principal museu de arte do Rio de Janeiro. A queima do acervo e de seus arquivos acarretou para os estudantes de arte desse período uma deficiência de fontes de estudo, cabendo à Escola de Artes Visuais do Parque Lage suprir essa necessidade. O estudo das artes tornava-se, então, refém de reproduções de livros e revistas, e Beatriz Milhazes não se distanciava dessa dinâmica, tal como nos aponta Herkenhoff (2007, p. 18): "Vivendo numa cidade sem museus e bibliotecas de artes desde o incêndio do MAM e isolada da cena internacional, Milhazes frequentava a biblioteca da EAV. No Brasil, as bibliotecas suprem na formação dos artistas a deficiência de coleções públicas".

O contato de Milhazes com artistas como Thomas Gainsborough, Joshua Reynolds, Howard Hodgkin, Matisse, Andy Warhol, entre outros, portanto, ocorre principalmente por meio das reproduções nos livros e nas aulas que frequentava no EAV Parque Lage com orientação de Charles Watson. Essa orientação, no que diz respeito à artista, influenciou no sistema de pintura que a artista utiliza até a atualidade. Herkenhoff $(2007$, p. 25$)$ analisa que

Para entender o sistema de pintura de Beatriz Milhazes, é necessário, portanto, entender seus estudos sob orientação de Charles Watson, quando já definiam aspectos que têm marcado até aqui seu projeto de obra. Ela 
ressalta a base constituída pela orientação conceitual de Watson e, ao mesmo tempo, o estímulo que dava a suas inquietações, que incluíam o fascínio pelo carnaval e pela padronagem de tecidos populares (como o dito chitão), que apareceram na Tropicália de Hélio Oiticica. Watson tinha consciência de algo semelhante à tarefa do educador defendida por Haroldo Rosenberg: a educação do artista significaria imbuir os estudantes de arte da "habilidade de abarcar a cena contemporânea com um entendimento crítico". Essa é a base das atitudes de Milhazes no sentido de não hierarquizar as fontes de referência.

Nesse sentido, a orientação de Watson contribuiu para a artista adicionar elementos em suas pinturas que fossem carregados de significados. Em entrevista com Herkenhoff (2007, p. 45) a artista declara que em sua fase inicial "não havia uma listra para a qual eu não tivesse que ter uma explicação". Essa necessidade de retorno à ordem da artista se vê presente nas cores exuberantes colocadas em contraste com trechos de tecidos, acrescentando linhas geométricas que dividem a pintura, tornando-a uma expressão racional de todas as suas inquietações e interesses. Retomando a ideia de Morais (1991), que a arte da geração 80 rememorava a emoção e o prazer, a arte de Beatriz Milhazes dava um passo a mais ao colocar regras às suas emoções, prazeres e interesses pessoais.

Antes de nos adentrarmos nos pontos de inserção da artista no sistema da arte, faremos uma contextualização de como era a dinâmica do sistema na década de 1980, as particularidades e mudanças em relação aos períodos anteriores.

\section{III.1.1 O sistema das artes na década de 1980}

De maneira a contextualizar o sistema das artes no período inicial em que a artista atuou, recorremos ao estudo realizado por Tadeu Chiarelli em 1987, no Centro Cultural São Paulo, que tinha por objetivo entender a inserção dos artistas paulistas no sistema das artes nas décadas de 1980 e início da de 1990, realizando entrevistas não estruturadas com artistas, visando encontrar similaridades entre os inícios de carreiras artísticas. Quando considera as trajetórias, Chiarelli (2012, p. 12) aponta que:

Pela primeira vez na História da Arte uma nova geração assume rapidamente todos os espaços artísticos das grandes cidades, "queimando" etapas tradicionais da carreira artística. Hoje em dia é comum as primeiras exposições desses artistas serem realizadas em museus, galerias de prestígio e até bienais, espaços até pouco tempo reservados a artistas mais velhos, cujas trajetórias dentro do campo da arte passavam por uma série de etapas, antes de alcançar esses espaços tradicionalmente consagratórios da carreira de um artista. Se até pouco tempo o museu, as galerias de prestígio e as grandes exposições internacionais eram o "campo de pouso" 
para artistas que já possuíam uma carreira solidificada através de várias pequenas exposições individuais e coletivas, participação em salões, etc., hoje em dia aquelas instituições tornam-se "plataformas de lançamento" de artistas extremamente jovens, muitas vezes sem amadurecimento de suas obras.

Por tratar-se de um momento transitório entre antigas políticas ditatoriais de censura e de controle para uma nova política democrática, o mercado da arte sofreu alterações significativas que iriam mudar completamente a dinâmica usada até então, tal como analisou Chiarelli (2012). Podemos entender que na década de 1980 no Brasil dá-se início ao sistema de rede seguindo o regime da comunicação proposto por Cauquelin (2005), que se opõe ao sistema de consumo que prevalecia até então.

Analisadas as diferenças entre os dos sistemas no capítulo II, faz-se necessário apontar algumas particularidades do sistema em rede proposto por Cauquelin (2005). A autora estabelece um sistema em tripé que conta com as três etapas: produção - distribuição - consumo, no qual os papéis se misturam, e é possível atuar em todas as partes do sistema. Uma consequência dessa mistura de papéis na rede é que, muitas vezes, um único ator tornase a rede total, considerando que atua em todas as etapas do sistema. Quando ocorre essa totalidade da rede provinda de um único ator, ocorre a saturação da rede, a qual Cauquelin (2005) aponta como falha do sistema por não poder sair de si mesmo. Para criar uma noção de individualidade dentro da rede, cria-se uma nominação que visa construir uma realidade pela linguagem, sendo esta o ponto crucial para a formação do regime de comunicação. A linguagem, a partir da análise estruturalista da autora, é usada para o entendimento da arte.

O produto do regime da comunicação é, portanto, a informação. As obras de arte ficam em segundo plano à informação, uma vez que dependem dela para serem validadas pela rede. Aquele que dispõe de meios para passar a informação adiante será o grande produtor desse regime. $\mathrm{O}$ regime do consumo utilizado na modernidade não contemplava essa distribuição constante de informação, os valores de suas obras não sofriam aumentos ou quedas especulativas, de acordo com a informação contida na rede alterando completamente o modus operandi do mercado de arte. "Essas transformações alcançam o domínio artístico em dois pontos: no registro da maneira como a arte circula, ou seja, no mercado (ou continente), e no registro intra-artístico (ou conteúdos das obras)" (CAUQUELIN, 2005, p. 65).

Quando consideramos essas noções para o contexto do mercado de arte brasileiro na década de 1980, momento transitório entre o regime de consumo para o regime da 
comunicação, percebemos que as mudanças sociais, políticas e econômicas que o país enfrentava também se refletiam no sistema da arte. Galerias de arte começavam a ganhar um espaço maior e mais significativo, auxiliando na internacionalização da arte brasileira e também na difusão em âmbito nacional. $\mathrm{O}$ aumento da renda das classes médias devido às aberturas econômica e comercial no fim do governo ditatorial no Brasil auxiliou a formação de um aumento dos colecionadores de arte, capazes de investir em artistas jovens e nas instituições do país, e permitiu que a arte produzida nesse período fosse amplamente difundida. A figura do curador também passou a ganhar um espaço maior dentro desse sistema, uma vez que atua, também, como crítico de arte e interlocutor entre as produções artísticas, artista, instituições e público consumidor.

A velocidade de inserção dos artistas dentro do sistema alterou-se rapidamente, fato que Chiarelli (2012, p.12) aponta como "uma geração que queimava etapas tradicionais da carreira artística": os artistas da geração 80 muitas vezes realizavam suas primeiras exposições em museus, galerias de prestígio e até mesmo em bienais de arte, espaços que até então ficavam restritos a artistas mais experientes que já haviam passado por inúmeras etapas de inserção mercadológica. $\mathrm{O}$ autor também entende que esses espaços transitaram de "campos de pouso" de artistas já consolidados para "plataformas de lançamento" de artistas jovens ainda em fase de amadurecimento. Para entender essas mudanças, Chiarelli (2012, p. 12-13) questiona:

Esta situação seria um fenômeno mercadológico? O sistema de arte simplesmente estaria fornecendo mais e mais produtos artísticos discutíveis para uma clientela cada vez mais ávida e menos exigente? Ou será que esses jovens seriam os únicos entre os artistas em geral que de alguma maneira refletiriam uma sensibilidade outra, mais pertinente a nossa época? (...) seria interessante refletirmos um pouco sobre o seguinte dado, que confirma a presença massiva de jovens nesse novo contingente de artistas.

Quando Chiarelli (2012) cita a imprensa não especializada como um veículo de difusão em massa, que impede uma análise mais acurada do que acontecia nesse momento, percebemos que, muito disso se dá por elevarem o status do artista visual a celebridade, considerando que, para além de sua produção artística, passaram a difundir também aspectos de sua vida pessoal, de seus gostos e dos locais que frequentava.

Nesse sentido, quando analisamos pela ótica da formação de branding, notamos que a abertura política e diminuição da censura auxiliaram para que começasse um maior desejo de profissionalização dos artistas e outros agentes do sistema. Durante a ditadura 
militar não era possível reuniões com grandes números de participantes, as discussões ocorriam com temor de denúncias e, as produções com receio de serem censuradas. Quando essa realidade se altera pelo fim do governo ditatorial há a reconstrução da democracia, notamos que os artistas visuais se permitem estar mais expostos e tomar as rédeas de suas carreiras, sem o medo da opressão do estado. Acompanha a ideia de profissionalização a de permanência no mercado de arte: se no regime do consumo que ocorria na modernidade, os artistas ansiavam por constantes rupturas e possibilidades de eterna reinvenção (tanto de suas produções, quanto do sistema em que atuam), no regime da comunicação, a permanência acontece junto ao desejo de estabilidade, à incorporação maior do mercado e à legitimação em seu meio. O desejo de uma maior integração com outros agentes também foi um ponto crucial para esse começo de profissionalização, uma vez que visavam a maior diálogo entre todos os atuantes desse sistema. Chiarreli (2012) entende que, muitos desses desejos, ocorrem por conta de os artistas terem vivenciado os novos meios de comunicação se formando e adquirindo seu local de importância no dia a dia da sociedade, como a televisão, as revistas, o cinema e, mais à frente, a internet, todos meios repletos de informações de rápida difusão que podiam atingir as diferentes camadas da sociedade. Por terem crescido cercados de informações e possibilidades de difusão, passam a entender que para além de serem meros produtores de obras, podem atuar nas outras esferas do sistema em rede, tal como propõe Cauquelin (2005).

Essa mudança de paradigma mostrou aos artistas maior noção da importância de estarem inseridos em todas as etapas que suas obras contemplassem, permitindo assim que tomassem as rédeas de suas trajetórias e que assim pudessem existir efetivamente uma carreira de artista dentro do meio, agilizando as etapas que antes poderiam levar décadas e, muitas vezes, não ocorreriam enquanto o artista ainda fosse vivo. A ânsia por uma legitimação de suas obras acarreta discussões sobre o que seria de verdade assimilado pelo sistema e difundido, fato que acabava por privilegiar estéticas que condissessem com os desejos de uma arte focada em prazeres e renovação dos suportes tradicionais desejados nessa época. Legitimar artistas dentro da rede e, em consequência, no sistema da arte, tornase um jogo de poderes, no qual os com maior munição tornam-se os vencedores: as munições aqui são entendidas como a informação, permitindo que os artistas que atuem em conjunto a outros agentes que propiciem que as informações sejam difundidas são legitimados com maior facilidade. O diagrama de Hargreaves McIntyre (2004), apresentado no capítulo II, nos demonstra a necessidade das relações dos artistas para que a legitimação ocorra, 
efetivamente, podendo ser aplicado à artista objeto deste estudo, Beatriz Milhazes, sobre a qual passaremos a tratar.

\section{III.2 A artista Beatriz Milhazes}

\section{III.2.1 Inserção no mercado de arte nacional e internacional}

A inserção da artista Beatriz Milhazes no mercado de arte brasileiro ocorre em paralelo às noções sociohistóricas levantadas nos subitem e capítulos anteriores e temos que ressaltar que, inserir-se em meio a um momento transitório pode resultar em uma faca de dois gumes, pois: é necessário adaptar-se ao novo período pós transição ou sua permanência no sistema será comprometida e, ao mesmo tempo, pode ser um benefício, uma vez que poucos estão a par das mudanças ocorridas. Então, as relações que a artista estabelece no começo de sua carreira se tornam de grande importância para esse momento de inserção no sistema da arte, pois permitiu que a artista participasse de exposições, tivesse difusão em mídias populares e ganhasse a atenção do público, tanto especializado quanto o público espontâneo. Quando consideramos o diagrama de ecossistema de Hargreaves McIntyre (2004) (Figura 10), percebemos que as etapas de inserção e início da legitimação no mercado de arte se dão principalmente, nas etapas de 1 até 4, sendo elas:

1. Artistas atraem reconhecimento dos pares.

2. Exposição curada por artistas ou curadores freelancers. Existe uma possível ramificação (2a) que é a representação em uma galeria de pequeno porte.

3. Produção e atividade atrai a atenção da crítica.

4. Atrai atenção de galeristas e marchands.

O ecossistema não prevê uma temporalidade específica para cada etapa, podendo variar conforme o contexto de cada artista. Evidenciamos aqui as análises de Chiarelli (2012) para o mercado de arte no final da década de 1980. Nesse sentido, a velocidade do sistema acelera e, em consequência, a velocidade das etapas prevista por Hargreaves McIntyre (2004) também se apressa, podendo até ocorrer etapas simultaneamente. 
Quando consideramos a artista Beatriz Milhazes, percebemos que as etapas de inserção no mercado ocorreram, muitas vezes, ligadas à EAV Parque Lage do Rio de Janeiro, local que a artista realizou seus estudos em arte. Suas primeiras exposições foram em 1983, no Salão Nacional de Artes Plásticas do Museu de Arte Contemporânea do Rio de Janeiro; e, na sequência, na Casa Rui Barbosa. Ambas as mostras visavam expor artistas emergentes jovens, recém graduados ou ainda em período de formação universitária, com intuito de auxiliar a inseri-los no sistema da arte. Tal como apontava Chiarelli (2012), diferente de gerações anteriores, muitos dos artistas da Geração 80 têm suas primeiras exposições já em instituições renomadas e Beatriz Milhazes segue nesse padrão, como veremos a seguir. Essas duas exposições serviram como pontes para que a artista participasse da mostra Como vai você, Geração 80?, ocorrida no ano seguinte na EAV Parque Lage, curada pelo júri do Salão Nacional de Artes Plásticas do MAM-RJ.

Figura 11 - Cartaz da exposição Quem é você, geração 80?, julho de 1984

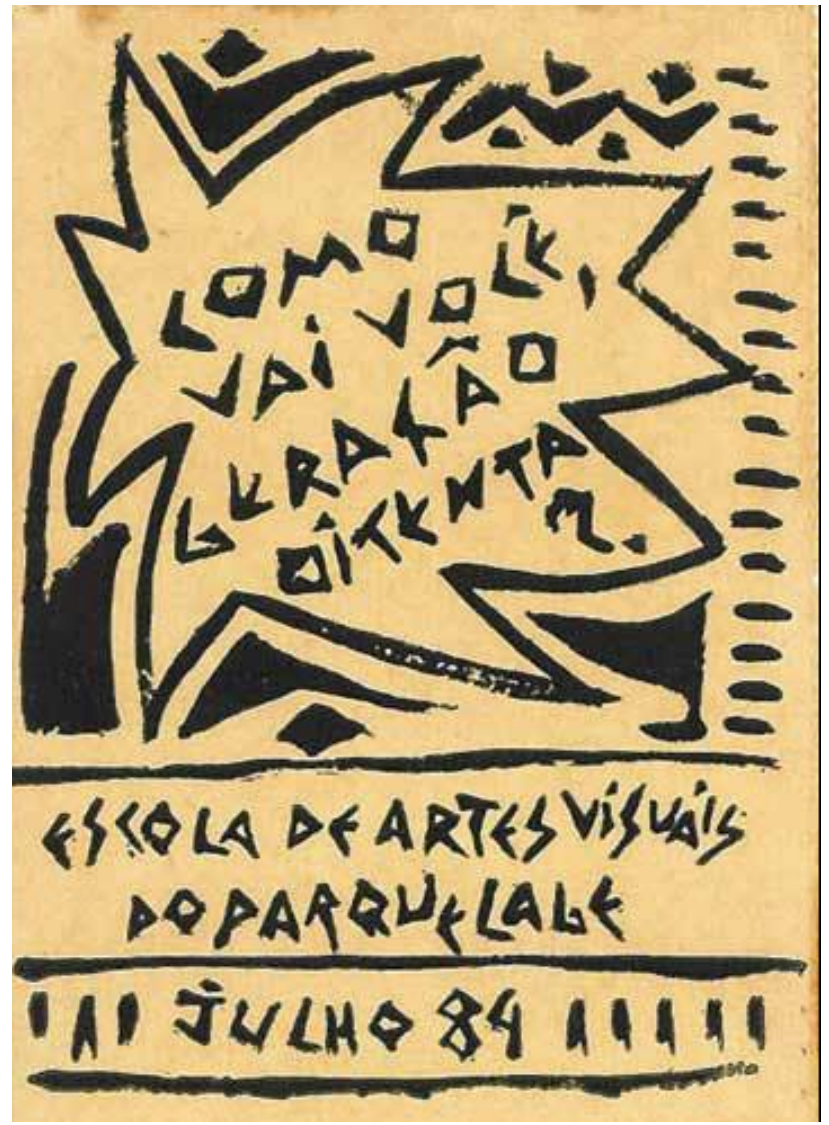

Fonte: Enciclopédia Itaú Cultural de Arte e Culturas Brasileiras (2018).

Essa exposição foi um marco para os artistas participantes, uma vez que os introduziu para um grande público, teve repercussões sucessivas na mídia e demarcou o começo de uma tentativa de profissionalização do mercado de arte. Diferente do Salão 
Nacional de Artes Plásticas do Museu de Arte Contemporânea do Rio de Janeiro que ocorreu um ano antes, a exposição possuía liberdades conceituais e não dependia de inscrições, júris e competições. Herkenhoff (1984) quando descreve a diferença entre o salão e a mostra, aponta que

[O Salão] é um processo mecânico, limita escolhas. É uma eleição de júri e uma competição entre artistas. É uma lei. Tudo isso subjuga o processo cultural e defasa seu resultado (a exposição destinada ao público). Ao fazer exclusivamente a política do artista, e não primordialmente a inserção da arte na sociedade, o Salão será o que tem sido nas últimas décadas: uma festa de inauguração com a presença dos expositores. Seu público são seus autores. Enfim, tudo o que a "Geração 80" não tem sido (HERKENHOFF, 1984, p. 26).

Diferentemente do salão, a exposição atraiu a atenção dos mais diversos agentes do sistema da arte: críticos, curadores, galeristas, jornalistas, sendo vista por alguns como um truque midiático fadado ao desaparecimento. As aparições dos artistas da Geração 80 na mídia estavam muitas vezes ligadas a fatores pessoais e não necessariamente às obras expostas, colocando um status de celebridade a esses artistas. Esse estado de emergência atribuído à Geração 80 pela mídia contribuía para os questionamentos referentes a qual era a data de validade do movimento, sendo entendido como algo passageiro e não uma geração que, uma vez inserida, permaneceria no sistema da arte. A exposição tinha, tal como citado por Herkenhoff (1984), o intuito de ser uma verdadeira inserção desses artistas no sistema, portanto, carregava responsabilidades para com estes artistas, fato que a mídia não deixava de lado ao se referir ao possível declínio dos artistas dessa geração. O crítico Frederico Morais (2001) atribuiu a estes artistas a reaproximação da arte com o público, trazendo-os para dentro de museus, galerias e até mesmo as bienais, uma vez que suas obras possuíam assuntos que eram de rápida assimilação do espectador, sendo tratados de maneira direta e sem seguir nenhuma tendência. Mas, ao elevar os artistas à categoria de celebridades, a mídia frisava a necessidade de reinvenção e contato ainda maior e mais direto com o público, entendendo que, caso se ausentassem dos holofotes midiáticos estariam fadados ao desaparecimento.

Entendendo que essa exposição já acontecia no contexto do regime de comunicação proposto por Cauquelin (2005), as informações que foram disseminadas acerca dela a tornaram um marco para os artistas que ali expuseram, tendo uma repercussão significativa. Quando consideramos o diagrama de ecossistema de Hargreaves McIntyre (2004), percebemos que a exposição Como vai você, Geração 80 ? foi um dos fatores que culminou na primeira fase de legitimação e inserção no mercado de arte da artista Beatriz Milhazes, 
fazendo-a completar as 5 primeiras etapas do diagrama. Em entrevista da artista em 2013, para a revista TPM, quando lembra da exposição de 1984 na EAV Parque Lage, analisa que:

Geração 80 foi montada pelos críticos que julgaram o Salão Nacional de Artes Plásticas da Funarte de 1983, no MAM do Rio. Eles viram um monte de pintores jovens trabalhando, um grupo efervescente, com coisas novas. Aí montaram a mostra. Mas ninguém tinha a menor ideia da proporção que isso ia tomar. Foi no pós-ditadura, a maioria dos artistas estavam na casa dos 20 anos e todo mundo da mesma geração estava louco para ver alguém criando alguma coisa que tivesse vida, cor, movimento. Foi uma enchente de gente no Parque Lage, uma demência, uma multidão. E havia os yuppies, que estavam surgindo nos anos 80 . Aí chegou um mercado e, esse mercado, atacou todo mundo. Foi uma reação em cadeia muito rápida. Mas nós não estávamos preparados. Então eu fui, assim, pé ante pé (MARTINHO, 2013).

A artista também explica que na época não tinha interesse de centrar seus ganhos monetários nas vendas, entendendo que se isso acontecesse teria que sucumbir a pressão vinda de galerias, colecionadores e de outros agentes do sistema (MARTINHO, 2013). Por isso começou a lecionar paralelamente às suas atividades como pintora, mantendo sua estratégia de criar seus vínculos antes de realmente aderir totalmente à dinâmica do mercado de arte. Nas exposições seguintes a Como vai você, Geração 80? podemos perceber que, mesmo ainda no início de sua carreira, Milhazes já apresentava um pensamento estratégico, no que se referia à sua trajetória e permanência no sistema da arte: realizava exposições individuais na cidade do Rio de Janeiro no contexto de galerias comerciais visando a uma maior difusão de suas obras no mercado de arte brasileiro e, no que se refere a exposições coletivas, começou o processo de internacionalização de suas obras. Sua primeira exposição fora do Brasil aconteceu no Japão em 1985 e depois em 1986 participou de uma mostra no México e, então, suas seguintes participações em mostras internacionais passaram a se concentrar principalmente na América Latina, retornando para a Ásia mais tarde, em sua trajetória, somente em 2006. Disseminar seu trabalho pela América Latina era algo que a artista almejava como forma de internacionalização de suas obras e, quando questionada sobre seus desejos de internacionalização, a artista afirma que

No início da década de 90, a Aracy Amaral, uma crítica importante de São Paulo, começou a organizar mostras de artistas brasileiros pela América Latina. Dos artistas da minha geração, ninguém estava a fim de América Latina. Queriam Estados Unidos, Europa. Mas eu achava interessante mostrar meu trabalho nesses lugares. Tinha interesse estético, sobretudo no México, os ícones religiosos, as igrejas barrocas. O Marcantonio Vilaça, que era colecionador e depois galerista, foi bem importante nisso. Ele abriu a galeria em São Paulo e começou a querer levar os artistas para fora. Teve visão. Tinha um lado aventuresco: a comunicação era difícil, era tudo por fax, as linhas brasileiras eram ruins. A coisa era capenga, exigia uma 
energia enorme. E a gente não queria expor em qualquer lugar. Queria o mercado interessante. Os museus, as galerias boas, as revistas de arte (MARTINHO, 2013, p. 25).

Esse processo de se estabelecer na América Latina contribuiu para uma maior visibilidade da artista no contexto do mercado internacional, acarretando representações por uma galeria na Venezuela, de 1991 até 1998, chamada Sala Alternativa, e também a sua primeira associação com galerias brasileiras, com a Subdistrito Comercial De Arte, no período de 1987 a 1990. Essas primeiras associações com galerias aproximaram a artista de colecionadores e curadores que, futuramente, tornaram-se fiéis da sua produção e a acompanharam no decorrer de sua carreira, mesmo após ter se associado a outras galerias. Sua entrada no mercado de arte ocorreu de maneira tímida, ou, nas palavras da artista, "pé ante pé", uma vez que estava no controle de cada passo que avançava no mercado.

Sua primeira individual realizada em outro país foi em 1993, em Caracas, na Venezuela, na Sala Alternativa, ocorreu quase que simultaneamente com a sua representação na galeria Camargo Vilaça, em São Paulo. Essa representação ocorreu após a Subdistrito Comercial De Arte, que a tinha no time de artistas até o momento fechou, e a associação com a galeria Camargo Vilaça se tornou essencial para a continuidade da difusão de suas obras no Brasil. A relação que a artista estabeleceu com a galeria deveu-se principalmente a um dos sócios fundadores, Marcantonio Vilaça. Antes de fundar a sua própria galeria, Vilaça colecionava obras de artistas contemporâneos e atuava como um financiador de artistas em que acreditava: artistas, como o paulistano Nuno Ramos tiveram, graças a Vilaça, rendas mensais que os permitissem focar em suas obras e também oportunidades de apresentar sua produção para colecionadores (MORESCHI, 2009). Quando decidiu abrir a galeria em 1992, Marcantonio Vilaça associou-se à Karla Camargo e juntos abriram em São Paulo a Galeria Camargo Vilaça. Nos primeiros anos de funcionamento dessa galeria, o foco principal dos sócios era difundir a arte contemporânea no panorama internacional, não necessitando focar em lucros no primeiro momento.

A verdade é que nem eu nem o Marcantonio precisávamos viver do lucro da galeria. Foi o trunfo que nos permitiu crescer em meio à turbulência do período Collor. Tudo o que ganhávamos era reinvestido na própria galeria. Arriscamos sem medo do prejuízo e, em menos de um ano, a galeria estava no azul (CAMARGO, in MORESCHI, 2009).

Os galeristas entenderam a necessidade de participarem em feiras internacionais e, também, de estarem presentes nas exposições dos artistas representados em outros países. A galeria financiava a ida de seus artistas para os locais, auxiliava nas montagens e 
hospedagem para que os artistas pudessem ser vistos pelos agentes do sistema no país em que expusessem. No que se refere à Beatriz Milhazes, foi Marcantonio Vilaça que a aconselhou que suas obras com cores berrantes não fossem abandonadas, mas sim assimiladas pela artista como marca pessoal (MORESCHI, 2009). As noções de branding na produção da artista começam a se tornar claras nesse momento, ao associar-se a uma galeria em ascensão e difundir a sua obra no contexto nacional e internacional. A formação dos valores, discutidos no capítulo I desta dissertação, se estabeleceu a partir das relações que a artista passou a fazer dentro do sistema da arte, conforme sua carreira avançava e suas estratégias passavam a se concretizar.

Já nessa época, início de sua carreira, a artista tomou uma decisão em conjunto à sua galeria acerca de suas vendas: não produziria mais de 20 (vinte) pinturas anualmente, estratégia que manteria seu mercado aquecido e a alta procura às suas obras. Considerando o mercado sedento por novidades, cada obra nova da artista a colocaria de volta ao radar dos potenciais consumidores e, dessa maneira, contribuiria para uma maior difusão de sua produção (MORESCHI, 2009). A aplicação dessa estratégia ocorre até os dias atuais, mantendo listas de espera para compra de suas obras e renova, ao mesmo tempo, o senso de novidade cada vez que alguma se torna disponível no mercado. A galerista Márcia Fortes da Galeria Fortes D'Aloia Gabriel ${ }^{14}$ afirma que chega a ficar 4 anos sem nenhuma obra nova da artista para venda, podendo acontecer de levar telas já vendidas da artista para feiras só para recolocar seu nome em evidência, deixando claro que, apesar de não ter sempre obras disponíveis para venda, continua trabalhando em conjunto com a Beatriz Milhazes, visando a expandir a carreira da artista (KATO, 2001).

A inserção da artista no mercado de arte nacional e internacional e, também, a formação de seu branding ocorreram em ritmo acelerado, expondo em instituições já consagradas e atraindo rapidamente o interesse do público, da mídia e consumidores em geral, tal como previsto por Chiarelli (2012) em seu estudo acerca dos artistas na década de 1980. A associação de Milhazes com a galeria Fortes Vilaça e, em especial, também com o colecionador Marcantonio Vilaça formaram noções de co-branding que solidificaram os três valores de suas obras, sendo estes: o valor comercial, o social e o essencial (FINDLAY, 2012), tal como explorado no capítulo II. Ao associar-se com esses agentes, a formação de

\footnotetext{
${ }^{14}$ A galeria mudou de nome em 2016 quando Alexandre Gabriel passou a integrar a sociedade com Márcia Fortes e Alessandra D'Aloia, que assumiram a galeria em 2001 após a morte de Marcantonio Vilaça e a saída de Karla Camargo.
} 
discurso de suas obras firmou-se usando as táticas de Vilaça de aproximar as obras da artista a uma visão de brasilidade: "Ela apenas não tem medo de ser brasileira, com todo o colorido que isso pressupõe" (MORESCHI, 2009). As estratégias de manter as pinturas coloridas, diminuir a velocidade de sua produção e internacionalizar a partir da América Latina foram cruciais para formação do discurso de sua produção e também da sedimentação de sua marca nessas etapas iniciais de inserção nos mercados de arte nacional e internacional, colocando a artista e suas obras nos locais que desejavam e não cedendo, imediatamente, a demandas do mercado, visando então uma permanência tanto no âmbito nacional quando no internacional.

No ano de 1996 ocorreu a primeira exposição individual da artista na Edward Thorp Gallery, sediada na cidade de New York, Estados Unidos e, em paralelo, a artista participava do festival Carnegie International em Pittsburgh. As mostras atraíram a atenção da mídia estadunidense sobre a artista, rendendo sua primeira participação de grande tiragem na mídia internacional com o artigo de Roberta Smith (1996, p.27, sessão C.) no jornal The New York Times, no qual a autora tensiona o caráter decorativo das obras de Milhazes e analisa os elementos lúdicos das pinturas que aproximam as experiências da artista ao dizer que "elas [as pinturas] mostram uma artista olhando fundo para dentro de si e de suas raízes culturais e descobrindo o que dar à pintura que não tenha sido dado anteriormente" ${ }^{15}$. Esse artigo foi o primeiro publicado na mídia estrangeira sobre a artista, apresentando-a para os espectadores estadunidenses e, também, para consumidores potenciais de suas obras. Anteriormente a este artigo do The New York Times, a artista já havia participado de livros e coletâneas acerca de artistas latino-americanos, tais como o catálogo Regards d'Amérique Latine (1995), com texto escrito por Jacques Leenhardt, o livro coletânea Latin American Art of the Twentieth Century (1996), da editora Phaidon, e Brasil: La nueva generacíon (1991), com texto da Aracy Amaral, mas a sua participação era sempre conjunta a outros artistas, não a colocando no foco principal.

\footnotetext{
${ }^{15}$ Tradução livre de: "they show an artist looking deep into herself and her cultural roots and figuring what to give paiting that it hasen't quite had before" (SMITH, p. 27, sessão C, 1996)
} 
Figura 12 - Obra $\mathrm{Nu} A z u l$, de Beatriz Milhazes, acrílico sobre tela (1996), exposta na individual na Galeria Edward Throp, Nova Iorque

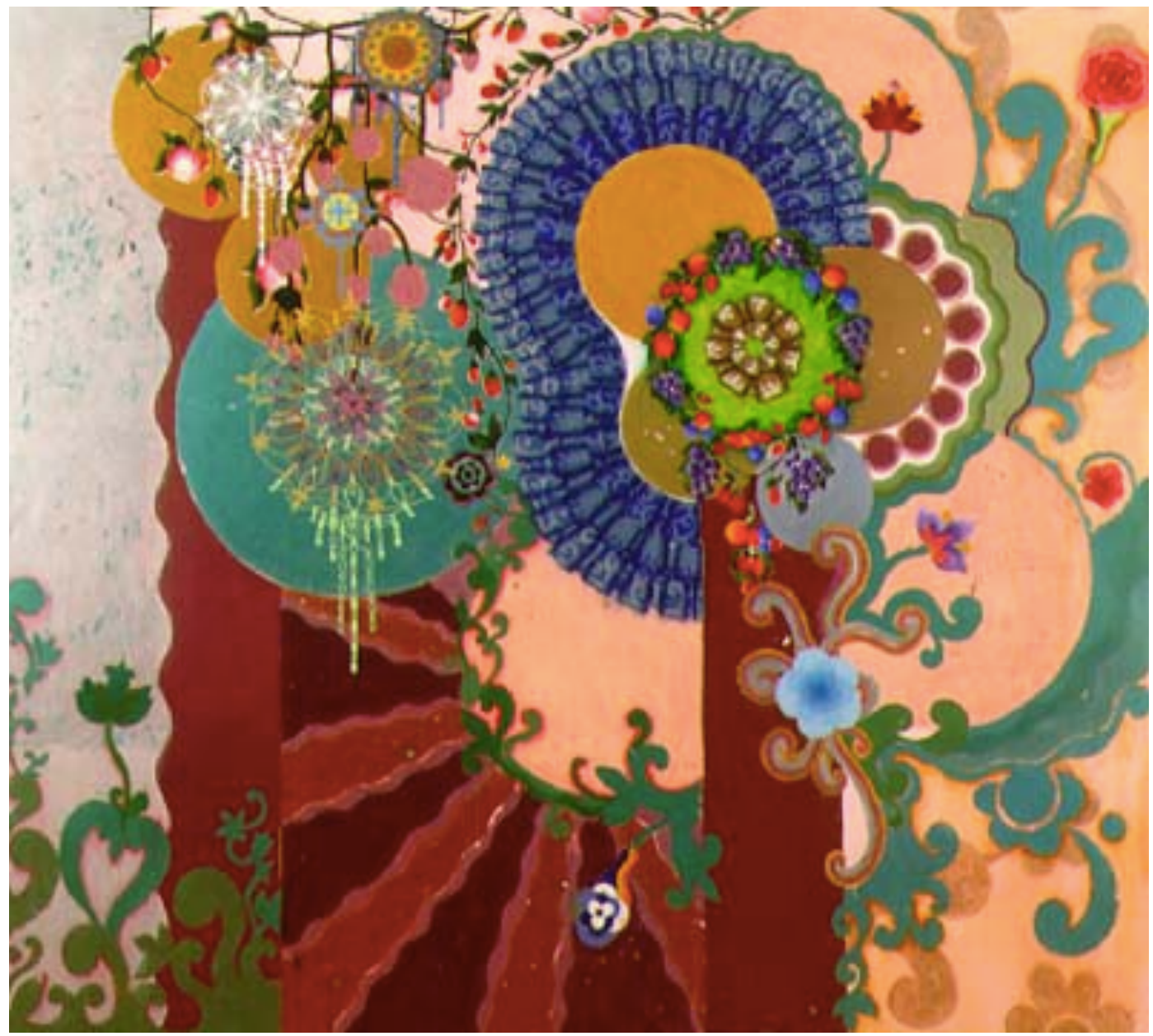

Fonte: Reprodução.

Nesse momento, sua produção passa a chamar a atenção dos agentes do sistema da arte norte-americanos que, entendendo a relevância que a artista estava construindo pela América Latina junto a críticos, curadores e colecionadores, passam a colocá-la em evidência quando se tratava da arte contemporânea brasileira. $\mathrm{O}$ caráter decorativo de suas obras, tal como Smith (1996) cita em seu artigo, contribuiu para uma maior aproximação a esses agentes internacionais, uma vez que misturava simetrias muito definidas em conjunto as cores extravagantes e temas tipicamente brasileiros.

"Não quero uma beleza fácil", ela [Beatriz Milhazes] diz analisando as obras. "Quero conflito. Quero intensidade, diálogos fortes, movimentos desafiadores dos olhos." A obra de Milhazes é rebeldemente barroca e rigorosamente estruturada. O olho fica pulando pela pintura como uma bola de fliperama mantida em contínuo movimento por um jogador tarimbado. "Os colecionadores acham difícil pendurar minhas obras em suas casas. Quando penduram um quadro, eles se dão conta de que 
precisarão tirar todas as outras coisas da sala!", observa com uma breve gargalhada, acrescentando que suas obras são também um desafio para os curadores de exposições coletivas. Segundo a própria Beatriz, suas pinturas possuem o esplendor de "um elefante e não de uma moça simpática" (THORTHON, 2009, p. 100).

Esse conflito que a artista propunha interessou ao mercado internacional, pois colocava em choque as questões de arte decorativa e, ao mesmo tempo, com uma metodologia clara e quase obsessiva trazia a geometria e referências de outros movimentos da pintura (HERKENHOFF 2007). Considerando as tendências que o mercado internacional passava a seguir nessa época, podemos notar a presença de temas quase abstratos, sem compromisso com o realismo e o neoexpressionismo, tal como proposto por Morais (1991) quando afirma que a arte da geração 80 se permitia o reencontro com o prazer e as emoções, afastando-se de uma arte hermética e fria.

A artista Beatriz Milhazes firma nesse momento a sua representação com a Edward Thorp Gallery em que estava expondo (mantendo essa representação até os dias atuais), iniciando sua participação ativa no mercado de arte estadunidense. Seguindo com a sua estratégia de realizar poucas pinturas ao ano, como combinado com Marcantonio Vilaça, a artista adicionou uma nova estratégia que se tornaria decisiva em sua carreira: continuaria vivendo e produzindo no Rio de Janeiro, não cedendo às pressões da galeria norte-americana de se mudar para Nova Iorque. Essa decisão impactou diretamente a sua carreira até os dias atuais, uma vez que ela escolheu arcar com custos de transporte das obras, deslocamento próprio e seguro das pinturas e, por consequência, não tem contato constante com colecionadores norte-americanos, apenas em momentos necessários, deixando para suas galerias essa aproximação. Milhazes acredita que se tivesse feito a sua mudança para os Estados Unidos teria "caído na tentação de Nova Iorque"16: a tentação referida por ela é ampla, envolve desde o custo de vida na cidade em comparação ao Rio de Janeiro; a oferta abundante de exposições, palestras e conteúdo para explorar; além das distrações que poderiam afetar a sua produção. A artista alega que prefere visitar Nova Iorque e realmente aproveitar a cidade, sem o compromisso de administrar seu próprio ateliê neste local. Essa decisão demonstra uma consciência de branding para a sua própria carreira e produção, uma vez que é feita a partir de decisões estratégicas, visando a preservar a própria marca, não cedendo às pressões de galeristas ou do próprio sistema.

\footnotetext{
${ }^{16}$ Retirado da entrevista realizada com a artista.
} 
Considerando as etapas de 1 a 4 do diagrama de Hargreaves McIntyre (2004) podemos notar que, quando aplicadas à Beatriz Milhazes, ocorreram com uma velocidade elevada, mas sempre com o aval da artista. Mesmo sem conhecer previamente os conceitos do marketing acerca do branding, a artista o executa de maneira intuitiva ao tentar prever os próximos passos de sua carreira desde o princípio e sempre se proteger para não perder o controle de sua própria produção. As associações feitas com outros agentes tornam-se associações empresariais, racionais e estratégicas, uma vez que tem como foco disseminar suas obras nos contextos nacional e internacional, exposições pontuais nos locais que a artista e seus pares julguem adequados e vendas calculadas, sem ter uma oferta excessiva que não façam suas obras circularem. O co-branding realizado com esses outros agentes nos permitem perceber que este ocorre de forma a serem associações de empresas, visando a dar ao consumidor uma experiência calculada pelos envolvidos, sem espaços para erros.

\section{III.2.2 Estratégias de permanência nos mercados nacional e internacional de arte}

Uma vez cumpridas as etapas de 1 a 4 do diagrama de Hargreaves McIntyre (2004), a artista passou para a segunda parte do processo de legitimação previsto pelo autor, contemplado pelas etapas de 5 a 12 do diagrama, que se constituem de:

5. Atrai atenção de colecionadores privados.

6. Galeristas constroem a reputação do artista por meio de vendas, incluindo sua presença em feiras internacionais.

7. Galeristas criam aval da crítica por exposição/vendas em outras galerias ou espaços independentes de pequeno porte.

8. Compra ou exibição de obras em galerias de grande porte.

9. Legitimação aumenta o valor e status do colecionador e também lucro para galeristas e artista.

10. Colecionadores emprestam obras para coleções públicas.

11. Atuação dos colecionadores é aumentada, resultando em convites para participar em conselhos dos museus.

12. Colecionadores disputam as obras em galerias. 
A partir da etapa 5 os valores das obras já estão estabelecidos para o mercado de arte, assim como o discurso. Já associados com galerias, cabe a estas formarem a reputação da artista perante o público consumidor da galeria, além de facilitar aproximações com novos consumidores, entendendo-os para além do ato da compra, como os visitantes de exposições; participação maior da artista na mídia popular de grande difusão, entre outros.

Como já dito, a partir do momento que a artista passou a ser representada pela Galeria Camargo Vilaça em São Paulo (a partir de 1993) e, alguns anos mais tarde (1996), na Edward Thorp Gallery em Nova Iorque, começou a participar ativamente nos mercados de arte nacional e internacional. Nesse estágio de sua carreira a artista deixou seu trabalho como professora para dedicar-se totalmente à sua produção artística. A partir daí notamos o volume de suas exposições aumentando e a projeção da artista ganhando força perante o sistema; culminando, em 1998, na sua participação na 24a Bienal de São Paulo com curadoria de Paulo Herkenhoff e Adriano Pedrosa, popularmente conhecida como Bienal da Antropofagia ${ }^{17}$ por celebrar os 70 anos do manifesto antropofágico de Oswald de Andrade e fazer uma reflexão acerca dos impactos desse movimento na cultura brasileira. Essa Bienal foi considerada pela revista norte-americana Artforum (2000) como uma das principais exposições da década de 1990, recebendo um público de mais de 500 mil pessoas (OLIVEIRA, 2001).

${ }^{17} \mathrm{O}$ nome da exposição foi, na verdade, Um elentre outro/s e ocorreu de outubro a dezembro de 1998. 
Figura 13 - Vista da obra Gavião e passarinho, de Beatriz Milhazes na 24a Bienal de São Paulo (1998)

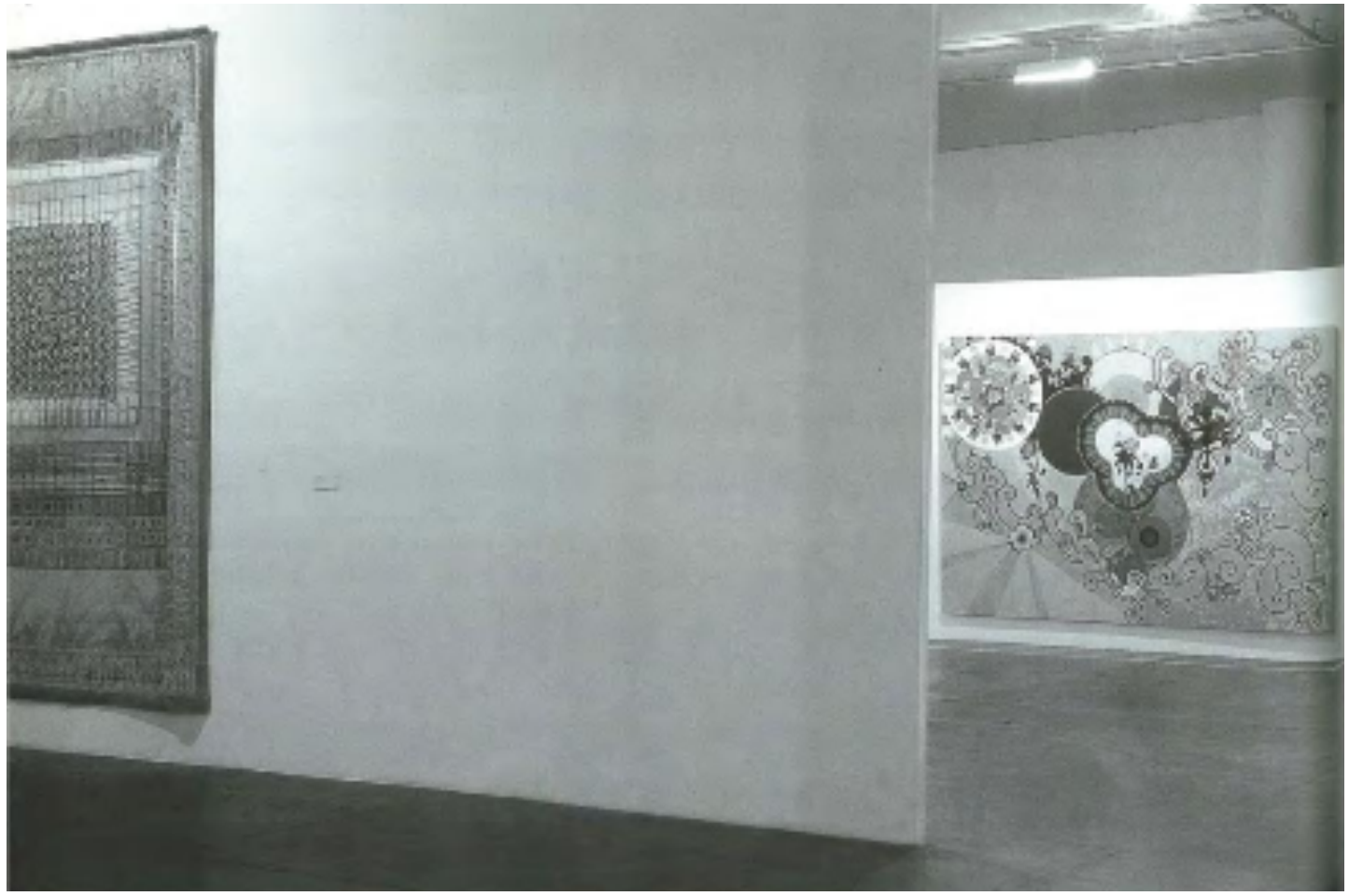

Fonte: HERKENHOFF; PEDROSA (1998, p. 94).

Figura 14 - Obra Gavião e passarinho, acrílico sobre tela, 250 x $350 \mathrm{~cm}$ (1998)

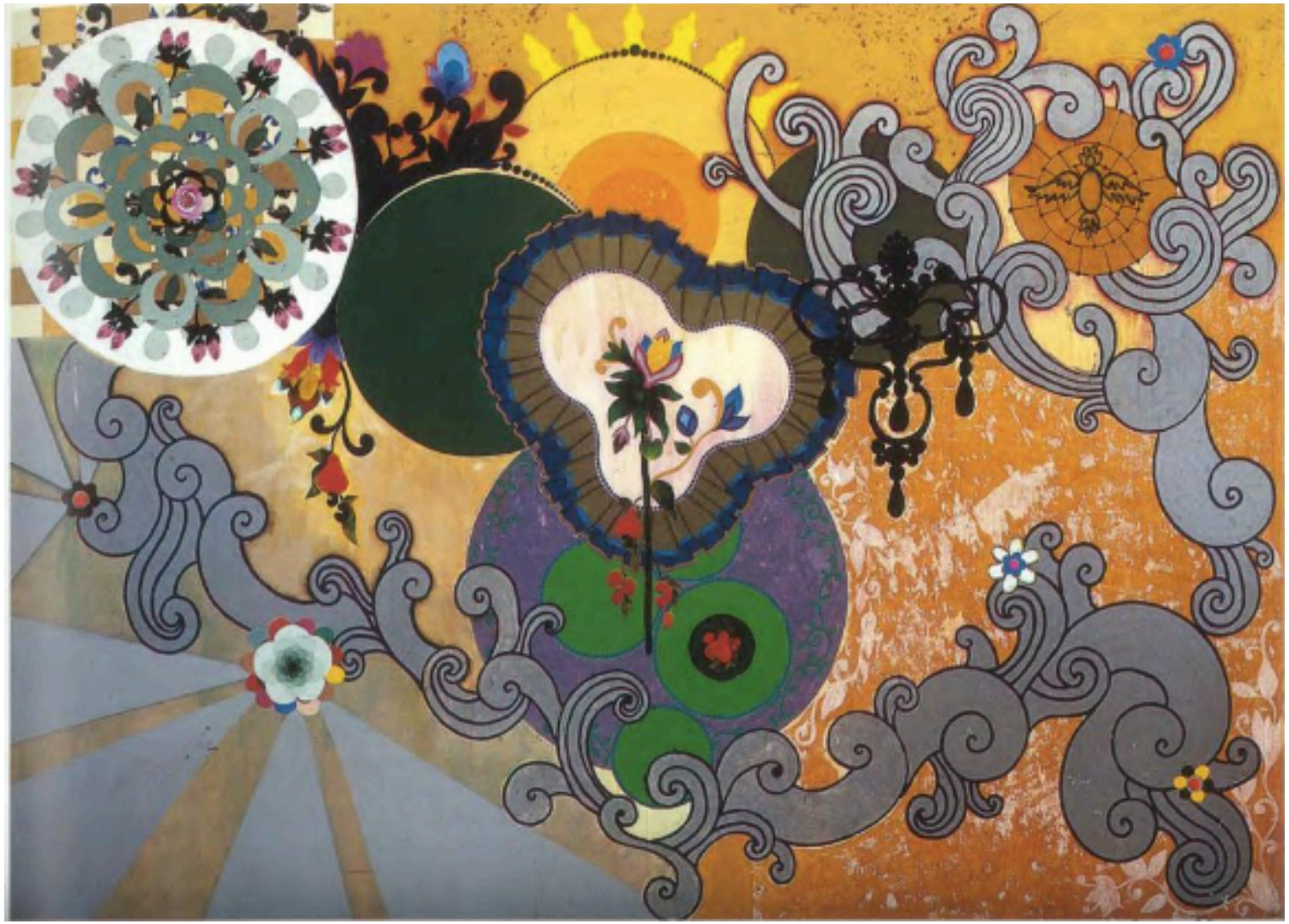

Fonte: HERKENHOFF; PEDROSA (1998, p. 95). 
Percebemos que em 1998 a artista participou pela primeira vez de um volume grande de mostras internacionais, tais como a XIV Bienal de Sydney (Austrália), Decorative Strategies no Center for Curatorial Studies Bard College (Estados Unidos) e Um Olhar Brasileiro, Coleção Assis Chateaubriand no Haus der Kulturen der Welt de Berlim (Alemanha). Sua projeção passa a ser para além das Américas, ampliando-se para a Oceania e Europa, ganhando espaço no mercado de arte internacional em parceria com as galerias que a representam. Nesse momento, quando consideramos o diagrama de Hargreaves McIntyre (2004), notamos que seu processo de legitimação perante o sistema está completo, tendo cumprido as 12 etapas. A segunda parte do diagrama (etapas de 5 a 12) ocorre de forma simultânea e com uma velocidade muito maior que as etapas da primeira parte: assim que sua reputação é construída, quase que automaticamente passa a atrair a atenção de colecionadores ávidos por adquirirem obras da artista em ascensão, e, devido à sua estratégia de produzir poucas obras anualmente, suas obras são disputadas entre os colecionadores e geram listas de espera para compra.

Permanecer nesse sistema é o maior desafio, uma vez que a artista Milhazes tem sua carreira legitimada. O público consumidor passa a acompanhar a trajetória da artista, consumindo notícias de jornal, livros, programas de televisão, exposições e aparições públicas que a artista pudesse fazer, sendo reconhecida por agentes sociais (LIPOVETSKY, 2014).

Quando exploramos no capítulo 1 a criação de valores das obras de arte, analisamos que o valor comercial estava diretamente ligado à ideia do artista como agente social, uma vez que estimula os desejos dos consumidores, podendo sofrer alterações conforme as ações do artista agradam ou não a esses consumidores. Em entrevista para esta dissertação, a artista afirma que não buscava sucesso, mas ter possibilidades de realizar seu trabalho como artista e poder continuar trabalhando à sua maneira. Ao considerarmos as estratégias adotadas pela artista de não se associar a primeira galeria que oferecesse representação, realizar poucas pinturas no ano, e não se deixar levar pelo senso imediatista atribuído à Geração 80, percebemos que foram estratégias cruciais para a permanência da artista após a sua legitimação. Logo nos primeiros momentos de sua carreira, ela assumiu o controle de sua trajetória, visando a atuar de maneira empresarial e profissional, ações que até então não eram atribuídas aos artistas, mas apenas às galerias que os representavam. 
Após a sua legitimação, ocorreram eventos que demonstram a eficácia de suas estratégias no longo prazo, como a sua participação no Pavilhão Brasileiro da $50^{\mathrm{a}}$ Bienal de Veneza e, no ano de 2008, sua obra $O$ Mágico bateu o recorde de obra mais cara de um artista brasileiro vivo vendida em leilão da Sotheby's em Nova Iorque, atingindo a cifra de US\$1.049 milhão. A partir de então, tornou-se a artista brasileira viva mais cara, criando uma disputa ainda maior para adquirir suas obras. Atualmente é representada pelas galerias Galeria Fortes D’Aloia Gabriel (Brasil), White Cube (Inglaterra, Estados Unidos, França e Hong Kong) Max Hetzler (Alemanha, França, Inglaterra e Japão) e Pace Gallery (Inglaterra, Suíça, Estados Unidos, Coréia do Sul e Hong Kong), tendo começado a avançar sua participação no mercado de arte asiático ${ }^{18}$. Seu ateliê possui uma equipe de gerenciamento que vai para além de assistentes para execução de suas obras, mas engloba assistentes comerciais e de gestão que auxiliam no cuidado de sua carreira. Como o mercado de arte tem suas vendas centradas, principalmente na pintura como suporte, a artista usa isso a seu favor para garantir sua permanência, tornando suas pinturas muito requisitadas entre os compradores; recentemente a artista passa a realizar colagens e projetos comissionados ligados à arquitetura, diversificando seu suporte e, dessa maneira, atinge públicos diferentes.

Figura 15 - Obra $O$ mágico, acrílico sobre tela (2001)

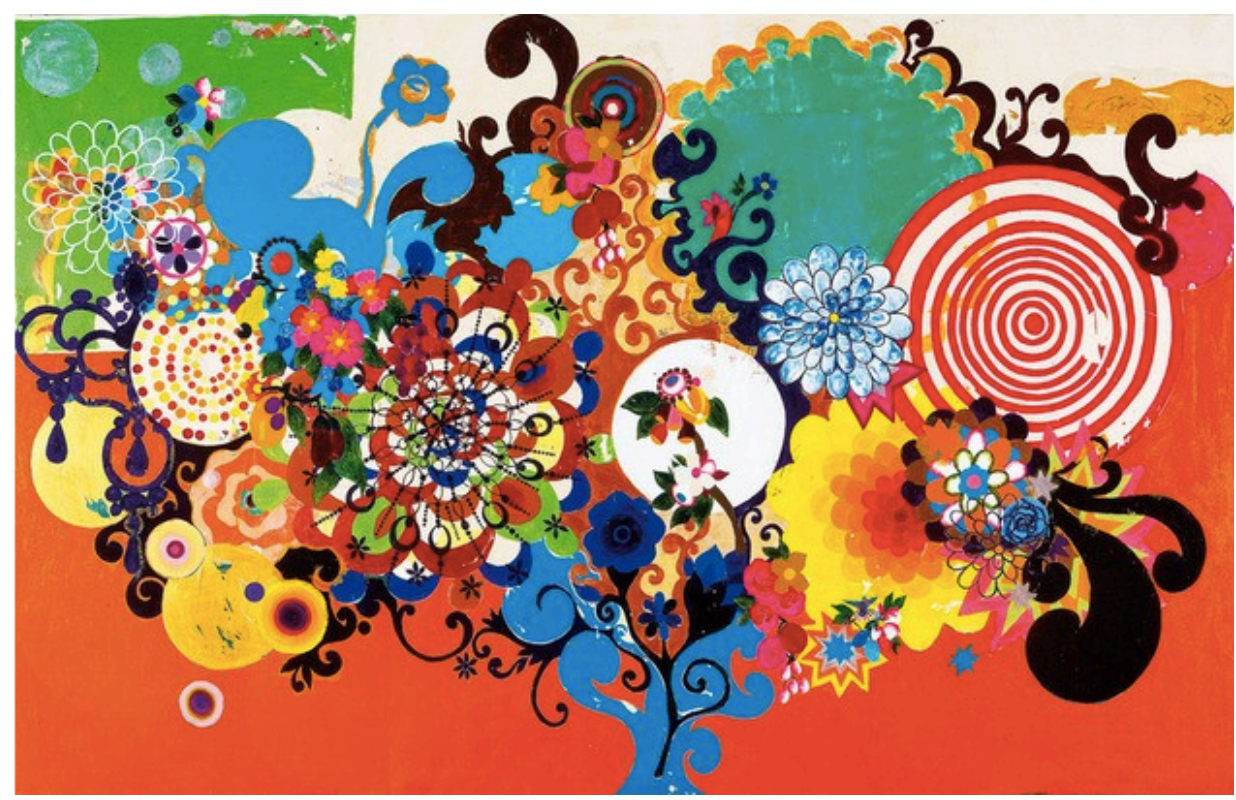

Fonte: Reprodução.

\footnotetext{
${ }^{18}$ Atualmente o único continente inexplorado de maneira mercadológica pela artista é o africano.
} 


\section{Tela de Beatriz Milhazes é vendida por R\$ 16 milhões}

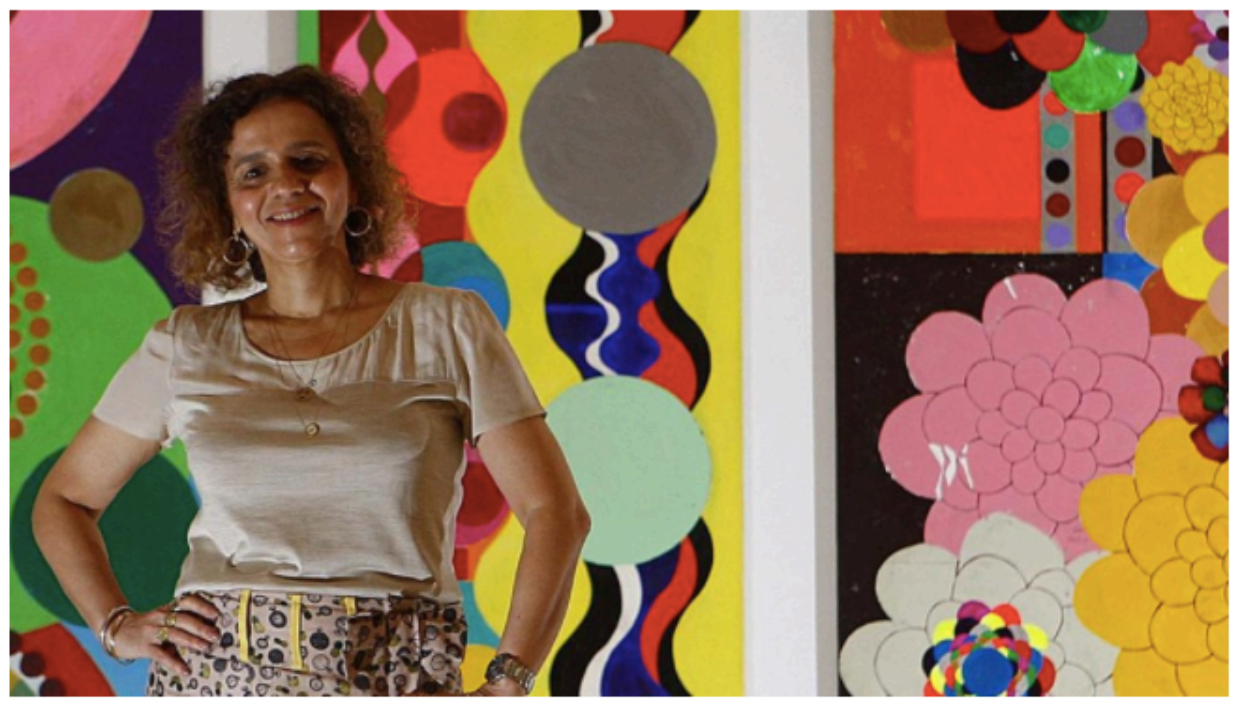

Mesmo no auge da crise econômica, uma tela da artista Beatriz Milhazes foi vendida por R \$ I6 milhóes na noite de abertura da feira SP-Arte, batendo todos os recordes da artista em leilóes.

Fonte: Gazeta do Povo, 07 abril 2016.

Para analisar de maneira prática a sua atuação durante e após a sua legitimação realizamos um conjunto de gráficos (Figuras 17 a 20), analisando os países em que a artista atuou em exposições individuais e coletivas e, também, número de exposições individuais e coletivas que ocorreram em galerias comerciais ou instituições, tal como é possível ver abaixo.

Ao analisar as Figuras 17 a 20, percebemos que os países com maior concentração das exposições, tanto individuais quanto coletivas, são Brasil e Estados Unidos. Percebemos que a relutância inicial da artista em se associar a galerias sem antes possuir uma estratégia surtiu efeito: apesar de no início de sua legitimação a artista visar a atingir primeiramente a América Latina, uma vez que realizou a exposição individual nos Estados Unidos, em 1996, passou a participar ativamente nesse país expondo e comercializando suas obras, fato que continua mesmo após sua legitimação. Logo após o Brasil e os Estados Unidos percebemos, 
principalmente, os países europeus, como França e Alemanha, ambos em que a artista possui representação de galerias.

Figura 17: Países onde realizou exposições individuais (1985 até 2019)

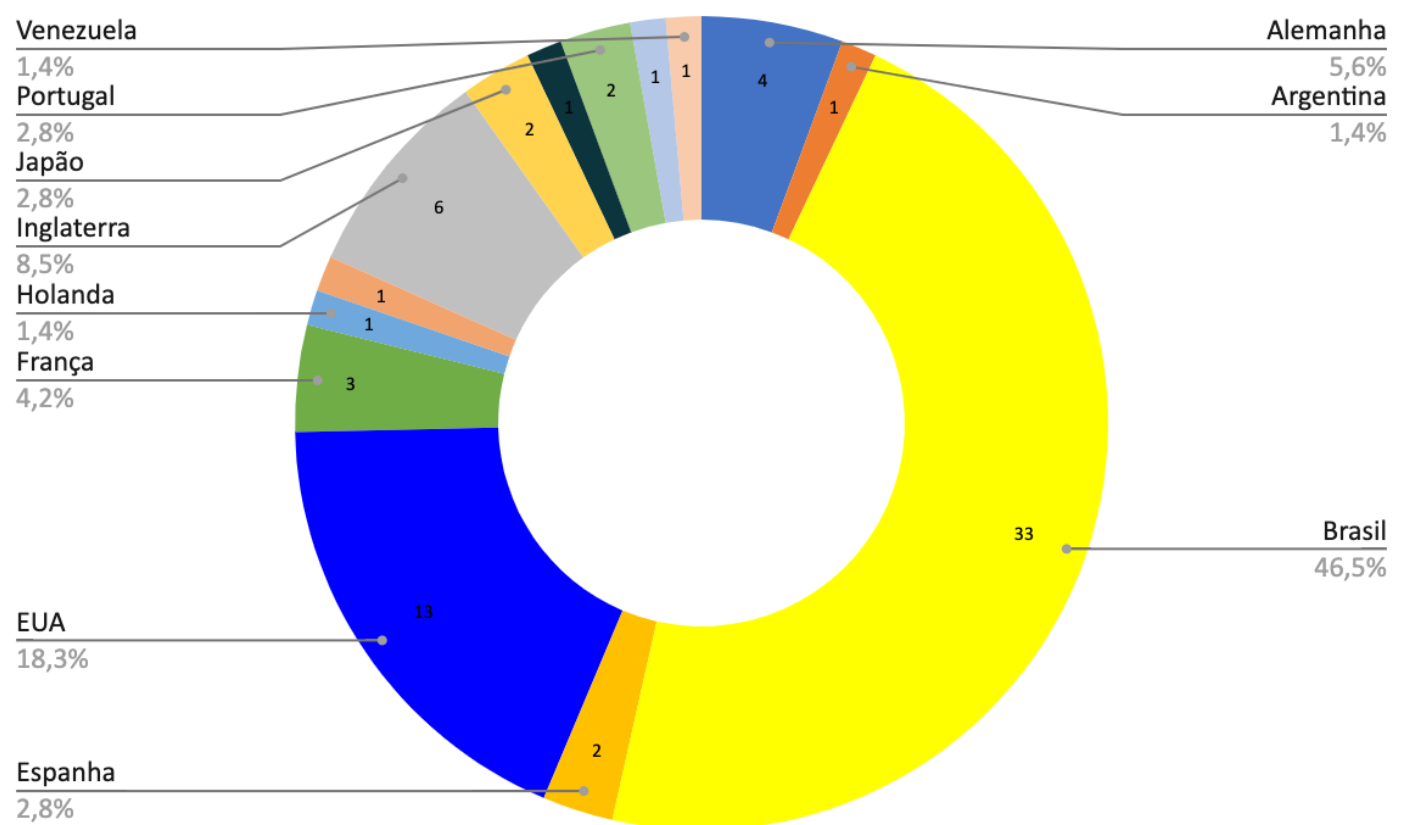

Fonte: Elaboração nossa.

Figura 18: Países em que realizou exposições coletivas (1985 até 2019)

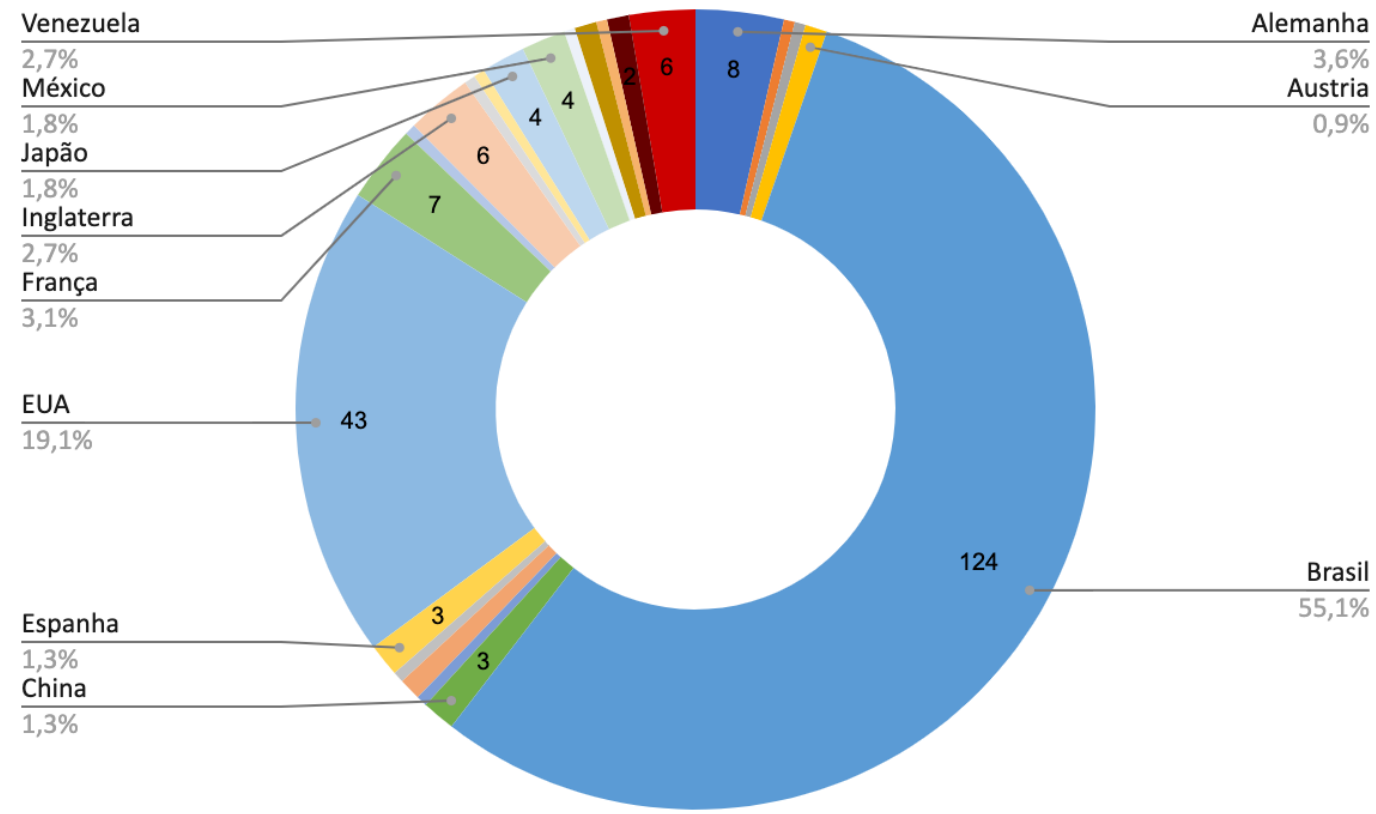

Fonte: Elaboração nossa. 
Quando consideramos exposições individuais notamos um maior número em galerias comerciais do que em instituições, fato que se deve especialmente pela estratégia da artista de não realizar um número muito elevado de exposições para assim conseguir manter um alto padrão de suas mostras e poder entregar ao público exposições com maior profundidade de pensamento e conceitos curatoriais, estratégia essa que entra em vigor quando passa a se tornar altamente requisitada pelas instituições, tal como comenta a artista em entrevista feita para esta dissertação.

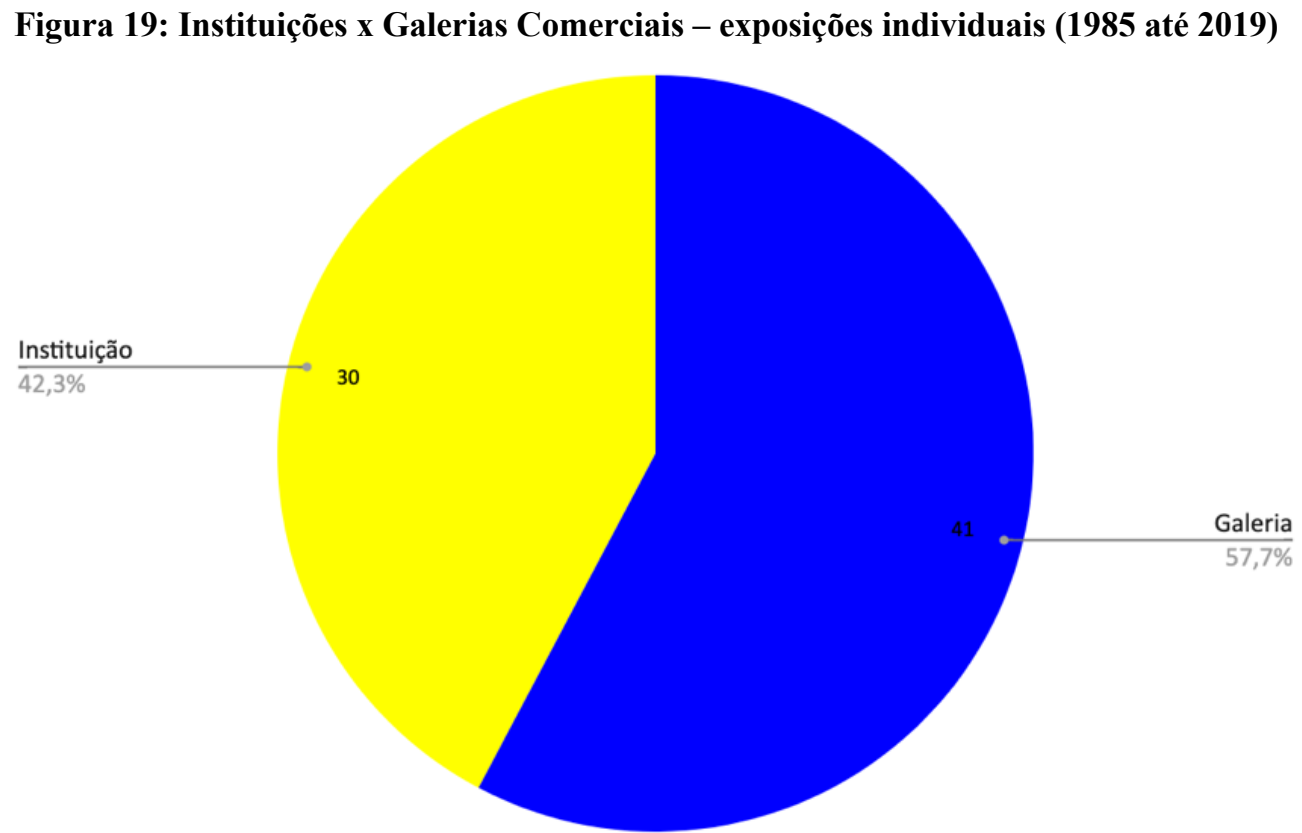

Fonte: Elaboração nossa.

As exposições coletivas, no entanto, ocorrem em maior parte em instituições, feito que se deve principalmente à presença das obras da artista nos acervos dessas instituições, permitindo uma maior liberdade para serem colocadas em exposição em diferentes momentos, dependendo do aval institucional para ocorrer. 
Figura 20: Instituições x Galerias Comerciais - exposições coletivas (1985 até 2019)

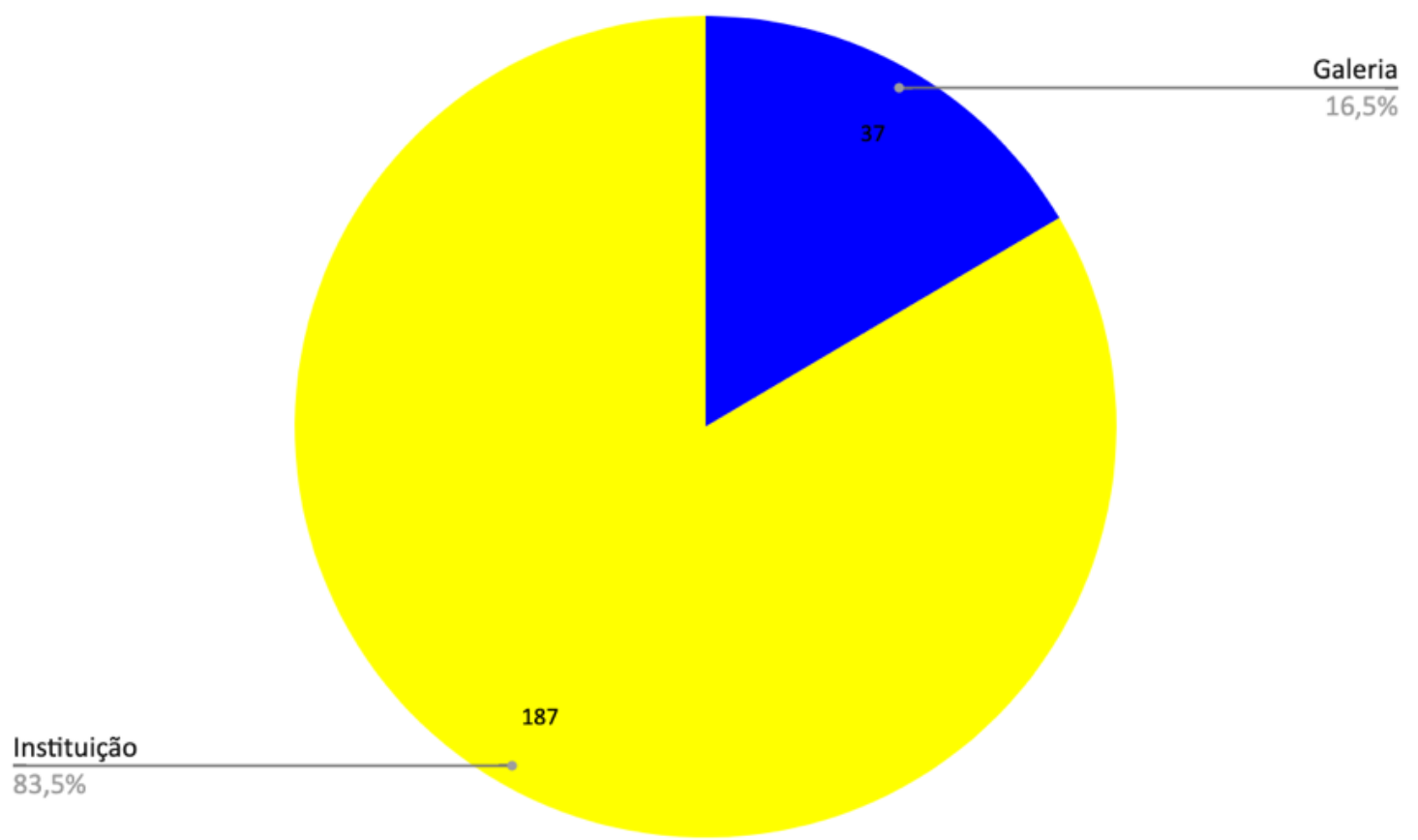

Fonte: Elaboração nossa.

Então, quando consideramos o branding, percebemos que ocorreu, primeiramente, de maneira intuitiva com o desejo de profissionalização da artista e, conforme sua legitimação vai tomando forma. A artista foi assumindo seu papel dentro desse processo ao escolher as suas associações com outros agentes e estratégias específicas de mercado que a beneficiassem, sem que esse controle fosse tirado de suas mãos. Seguindo as divisões de Preece e Kerrigan (2015), podemos afirmar que a artista conquistou seu branding a partir das visões estratégicas de sua marca, criando um brand equity que permitisse que os valores sugeridos por Findlay (2012) ocorressem e que todo o processo proposto por Hargreaves McIntyre (2004) para a legitimação fosse possível de ser aplicado integralmente. 


\section{CONSIDERAÇÕES FINAIS}

Este trabalho pretendia responder ao seguinte questionamento: de que forma as estratégias adotadas pelos artistas contemporâneos, considerados como marca, garantem que a legitimação e permanência no mercado de arte seja consolidada? No decorrer da pesquisa foram encontradas algumas dificuldades para obter possíveis respostas, sendo elas o contato direto com os agentes do sistema que se mostrassem dispostos a analisar as ações de legitimação de artistas e também o contato direto com Beatriz Milhazes para conseguir obter uma fonte primária de pesquisa. Essas dificuldades foram superadas no decorrer da pesquisa, tendo ocorrido entrevistas com a artista e com um agente do sistema. Outra dificuldade foi o cancelamento dos eventos, bibliotecas e necessidade de isolamento social no ano de 2020 devido à pandemia do COVID-19: quando os cronogramas da pesquisa tiveram que ser reprogramados e adaptados para ocorrerem a distância, sem contato presencial. Por esse motivo, os dados acerca do mercado de arte mostrados nos capítulos I e II não foram atualizados para o ano de 2018, uma vez que as pesquisas tiveram que ser pausadas para atender demandas mais urgentes em decorrência do momento de instabilidade econômica provocado pela pandemia.

O processo de legitimação de artistas contemporâneos, quando aplicado para o contexto brasileiro, necessita considerar especificidades do mercado de arte nacional. Ainda muito jovem, o mercado de arte brasileiro tem seu avanço depois da abertura comercial no pós ditadura militar, evento recente em nossa história. Por conta desse fator, o mercado ainda está em vias de ampliação, profisssionalização e colocação perante o sistema internacional. Também devemos considerar que a volta da democracia no país resultou em inúmeras mudanças no contexto social do país, inclusive no sistema de arte. A urgência atribuída à chamada Geração 80, em que a artista Beatriz Milhazes se coloca, foi questionada por muitos como algo temporário e passivo de desaparecimento, e coube à artista adotar estratégias próprias para a sua carreira para evitar seu desaparecimento. Os estudos de Chiarelli (2012), acerca da Geração 80, foram importantes para entender a mudança na dinâmica que esses artistas enfrentaram, entendendo que as instituições e galerias também passaram a atuar, visando à inserção de novos artistas no sistema nacional e também o desejo de internacionalização da arte brasileira. A inserção desses artistas ocorreu rapidamente, no 
entanto, as estratégias adotadas por eles, para permanência no mercado de arte foram cruciais para evitar seu desaparecimento.

Para a compreensão do termo "marca" foram estudados conceitos desenvolvidos por Kotler (2000). Esse autor não abarca conceitos ligados diretamente ao mercado de arte, no entanto, é possível usá-los como parâmetros para analisar a artista dentro do cânone da marca. As obras de Kotler são frequentemente atualizadas com a intenção de se manter em dia com as dinâmicas mercadológicas, levando em consideração que o contexto mundial, os gostos, a economia, a política e todas as áreas podem afetar essas esferas, pois são mutáveis e atuam de maneira conjunta, portanto, sofrem alteração das dinâmicas das marcas e do mercado como um todo. A necessidade de constante atualização é de interesse para o trabalho, uma vez que o mercado de arte também depende desses fatores, embora seja o produtor, o distribuidor e o consumidor atrelados às dinâmicas globais, o que nos permite uma aproximação direta aos conceitos mercadológicos. Para a análise está sendo utilizado o diagrama de Hargreaves McIntyre (2004) e também as teorias desenvolvidas por Robertson (2005), O’Reilly e Kerrigan (2010) e Horowitz (2011), para maior entendimento do funcionamento do sistema das artes na perspectiva do marketing.

Para os questionamentos referentes ao consumo, a teoria do "capitalismo artista", desenvolvida por Lipovetsky (2014), nos oferece o conceito de "capitalismo de sedução", utilizado atualmente como estratégia de venda para a manipulação do público consumidor, criando necessidades pessoais que somente os produtos comercializados irão satisfazer. $\mathrm{O}$ capitalismo artista abrange as marcas, para além do proposto aqui (artistas como marca), incluindo a personalização destes por meio de influenciadores. Para tratar o tema de rede criada pelos artistas-marca, os distribuidores e seus potenciais receptores (consumidores) são utilizados como base conceitos pautados em Anne Cauquelin (2005), que, de acordo com essa autora, constitui o sistema de trocas de bens materiais e simbólicos da modernidade, abrangendo o mercado de arte não apenas para a troca comercial de obras, mas também o de informação.

Ao aproximar as teorias de Lipovetsky (2014) e Cauquelin (2005) propomos um diálogo entre elas, especialmente para analisar a relação de rede entre os agentes do mercado de arte: os artistas-marca e os distribuidores que criam o capitalismo de sedução por meio das estratégias mercadológicas. No entanto, para que ocorram de maneira eficientes, ambas as estratégias são dependentes do público consumidor. Cada elemento da rede se torna 
dependente, então, de todas as outras partes para que o ecossistema do mercado de arte funcione.

São estudados, também, teóricos com estudos referentes ao mercado de arte, tais como Thompson (2014), Findlay (2012) e autores atuantes no sistema das artes, com o objetivo de traçar um panorama do mercado da arte internacional. No que se refere ao mercado brasileiro de arte, os dados levantados anualmente por Fialho (2017), na pesquisa setorial do Projeto Latitude, são importantes para a verificação das dinâmicas mercadológicas nacionais, indicando quais áreas mais crescem, quais se estabilizam e quais diminuem no âmbito brasileiro, além de análises da mídia social e entrevistas com agentes; e Chiarelli (2011), que fez um levantamento acerca do panorama da arte na década de 1980 (mais especificamente voltado para o estado de São Paulo) e os processos de legitimação dos artistas emergentes desse momento.

Assim, as referências baseiam-se, em sua maioria, em estudos que traduzem o mercado de arte, abarcando teóricos que analisam o consumo, a distribuição de obras/artistas para o público consumidor e também a produção das obras e das estratégias utilizadas pelos artistas para permanência no mercado. A escolha dessas referências permite o diálogo entre o objeto de pesquisa desta dissertação e os estudos existentes acerca do mercado de arte, sendo fundamentais para o desenvolvimento da pesquisa.

No capítulo I exploramos o mercado de arte atual, constatando que ainda está restrito ao sudeste do país, centrado nas cidades de São Paulo e Rio de Janeiro; apesar da dimensão geográfica do país, ampliando-se para o sul do país e o centro-oeste. Mesmo com um mercado em expansão, o processo de legitimação dos artistas contemporâneos atende aos critérios propostos por Hargreaves McIntyre (2004) que considerou o contexto do mercado de arte britânico, tornando possível aplicá-los ao mercado de arte brasileiro. No decorrer do levantamento de dados para esse capítulo percebemos que a profissionalização dos artistas, algo almejado pelos artistas e agentes do sistema da Geração 80, ainda está em processo. Ao constatarmos que existem inúmeras regiões do país que ainda não possuem um mercado de arte estabelecido, nos leva a questionar se não existe, também, uma necessidade de nacionalização das obras de arte brasileiras, e não apenas de internacionalização.

Apesar da difusão em mídias de massa, ainda existem regiões que não possuem acesso às obras de arte e às dinâmicas mercadológicas presentes principalmente no sudeste do país. Esse aspecto se aproxima do começo da década de 1980, quando ocorreu o incêndio no Museu de Arte Moderna do Rio de Janeiro, deixando o público carente de espaços para 
um contato direto com as obras. Apesar de não estar presente neste trabalho, a discussão do acesso às obras de arte também nos interessa uma vez que, percebemos que quanto mais acessível e democratizado o acesso às obras de arte, maior pode se tornar a procura pela profissionalização de todo o sistema.

No capítulo II levantamos a questão da legitimação dos artistas. A aplicação do branding em conjunto com a legitimação de artistas contemporâneos nos mostrou que isso auxilia para que esse processo ocorra de forma mais consciente e garanta uma maior independência do artista em relação à sua carreira. O branding garante que as estratégias aplicadas pelos artistas sejam de sucesso, visando a sua permanência no mercado de arte, criação de oferta e demanda para as obras e uma maior difusão de sua produção. Nesse capítulo foi possível juntar os conceitos de valores das obras definidos por Findlay (2012) com os de capitalismo de sedução de Lipovetsky (2014), levantados no primeiro capítulo, entendendo de que maneiras são aplicados na prática do mercado de arte. O diagrama em ecossistema de Hargreaves McIntyre (2004) nos permitiu visualizar todas as etapas da legitimação de um artista, entendendo que não necessitam ocorrer em um tempo definido e que possuem diferentes ordens, mas as etapas ocorrem com todos os artistas legitimados pelo sistema. A associação desses artistas com curadores, galeristas, marchands, colecionadores, entre outros, é de grande importância para que essa legitimação ocorra, uma vez que são esses agentes que difundem as suas obras e permitem uma maior visibilidade do artista perante o sistema. Essas associações foram entendidas aqui como co-branding, podendo ocorrer tanto no âmbito comercial quanto fora dele. A aplicação do branding e cobranding nos fez perceber que, conforme o artista se torna mais profissionalizado no sistema, mais necessita de um entendimento acerca dos seus interesses mercadológicos e de carreira, o que o torna um profissional no mercado. Esses planejamentos ocorreram para a Geração 80 de maneira intuitiva, como apresentamos no capítulo III ao analisar a artista carioca Beatriz Milhazes. Entretanto, planejamentos feitos com consciência, visando a resultados pontuais, permitiram que os artistas permanecessem atuantes no mercado.

No capítulo III, exploramos a trajetória de Milhazes e demonstramos que a artista participou ativamente das tomadas de decisão referentes à sua carreira, criou estratégias para ter uma melhor atuação e permanência no mercado de arte. As associações que a artista fez no início de sua carreira foram baseadas em acordos empresariais que visavam a maior projeção de suas obras, de forma a atender a seus interesses. Essas estratégias permitiram que sua permanência no mercado de arte fosse garantida, mantendo sua carreira em contínua 
ascensão. No que se refere à artista, aplicamos o diagrama de McIntyre para analisar a trajetória (2004), visando a sua inserção no mercado de arte. Para compor essa análise, levantamos os dados de exposições realizadas pela artista nesse período, aparições nas mídias de massa e também entrevistamos a artista, para uma visão mais ampla do início de sua carreira. Nesse levantamento, percebemos que a artista sempre participou ativamente da tomada de decisões de sua carreira, criando estratégias específicas, visando a proteger a sua produção de um ritmo acelerado do mercado e também a prevenindo de desaparecer no sistema.

No momento em que ocorreu a exposição Quem é você, Geração 80?, a artista se resguardou de associar-se a todas as galerias comerciais que a abordaram tentando representá-la, buscando realizar as associações de seu interesse. A decisão de internacionalizar as suas obras, primeiramente na América Latina para só depois inseri-las nos Estados Unidos e Europa, foi um diferencial na trajetória da artista: conquistou um espaço cada vez maior em mercados em ascensão, aproximou-se de colecionadores de arte que tinham por objetivo investir em artistas emergentes e também de curadores em busca de novos artistas. Em 1996, a artista realizou a sua primeira exposição individual nos Estados Unidos e o jornal New York Times repercutiu o evento em suas páginas, aumentando ainda mais a difusão de suas obras no sistema de arte.

Analisar a trajetória de Beatriz Milhazes em contraponto ao diagrama de Hargreaves McIntyre (2004), nos permitiu perceber que, para que as etapas ocorram, é necessário muito investimento da parte do artista: não apenas monetário, mas também social, conceitual e de tempo. Para que os valores de suas obras sejam criados e legitimados nesse sistema, o artista precisa constantemente apresentar novas obras, novas exposições e aparições, demonstrando que, para se tornar um artista-marca, o artista precisa também ser uma figura social, conforme proposto por Lipovetsky (2014). O branding auxilia nesse processo para tornar a legitimação uma atuação profissional e não apenas de cunho social. Podemos perceber que o caso de Beatriz Milhazes obteve sucesso, uma vez que suas estratégias acarretaram na sua permanência no mercado de arte brasileiro e sua inserção no mercado de arte internacional, atingindo a América, Europa e Ásia. A artista já realizou projetos que podem ser considerados grande marcos para artistas contemporâneos, tais como a participação na Bienal de São Paulo, Bienal de Veneza, além de sua participação em coleções de grande impacto como as do Metropolitan Museum, nos Estados Unidos. Hoje a 
artista participa de poucas exposições anualmente, uma vez que sua produção ocorre de maneira lenta, tal como planejado pela artista logo no início de sua carreira.

Atualmente, Beatriz Milhazes é uma das artistas viva cujas obras atingem cifras expressivas em todo o mundo. Suas obras possuem lista de espera para aquisição, sua agenda é planejada com antecedência, visando a atender a todas as demandas que surgem. $\mathrm{O}$ branding permitiu que sua carreira se tornasse sólida perante o mercado de arte, mostrando que as estratégias que a artista adotou logo no início de sua carreira e também no decorrer dela, foram essenciais para essa permanência. Em entrevista, a artista relembrou que esse processo de tomadas de decisões ao longo de sua carreira deve sempre ocorrer, pois uma decisão errada pode colocar em risco tudo o que construiu nas últimas décadas.

Este estudo enfrentou algumas limitações, tal como a natureza exploratória que foi adotada, no qual o estudo de caso restringe a análise apenas à artista escolhida, Beatriz Milhazes. Estudar apenas uma artista pode ser limitador quando consideramos toda a arte contemporânea e o mercado de arte brasileiro, no entanto nos auxiliou a um maior aprofundamento da metodologia em ecossistema e nos deu referencial para aplicá-lo em outros artistas provindos de outros contextos do Brasil. Os potenciais estudos futuros decorrentes desta dissertação se inserir nessa ampliação do escopo para outros artistas e agentes do sistema da arte, visando um maior entendimento do funcionamento do sistema da arte a partir da ótica do branding. Tal como notamos, a legitimação de artistas contemporâneos não ocorre isolada de outros agentes, mas sim em um sistema de redes, para tanto, estudar os componentes dessa rede seria uma possibilidade de ampliação deste estudo. 


\section{REFERÊNCIAS}

AAKER, D. A. The Value of Brand Equity. Journal of Business Strategy, v. 13, n. 4, p. $27-$ 32, 1992. Disponível em: https://doi.org/10.1108/eb039503. Acesso em: 20 ago. 2020.

BASOLE, R. C.; KARLA, J. On the evolution of mobile platform ecosystem structure and strategy. Business \& Information Systems Engineering, v. 3, n. 5, p. 313-322, 2011.

BAUMANN, S. A General Theory of Artistic Legitimation: How Art worlds are like social movements. Poetics, v. 35, n. 1, p. 45-65, 2007.

BEATRIZ Milhazes. In: ENCICLOPÉDIA Itaú Cultural de Arte e Cultura Brasileiras. São Paulo: Itaú Cultural, 2020. Disponível em: http://enciclopedia.itaucultural.org.br/pessoa9441/beatriz-milhazes. Acesso em: 04 fev. 2020.

BRITO, R.; CALDAS, W.; RESENDE, J.; ZILIO, C. [1976] O boom, o pósboom e o disboom. In: BASBAUM, R. (Org.). Arte Contemporânea Brasileira: texturas, dicções, ficções, estratégias. Rio de Janeiro: Rios Ambiciosos, p. 179-196, 2001.

BULHÕES, M.A. Antigas ausências, novas presenças: o mercado no circuito das artes visuais. In: GONÇALVES, L. R. (Org.). A Arte Brasileira no Século XX. São Paulo: ABCA; MAC USP; Imprensa Oficial do Estado de São Paulo, p. 265-282, 2007.

CASTELLS, M. A Era da Informação: Economia, Sociedade e Cultura. In: A Sociedade em Rede. Lisboa: Fundação Calouste Gulbenkian, 1996.

CAUQUELIN, A. Arte Contemporânea: uma introdução. São Paulo: Martins Fontes, 2005.

CHIARELli, T. No Calor da Hora: dossiê jovens artistas paulistas, década de 80. Belo Horizonte: C/Arte, 2012.

CHIZZOTTI, A. Pesquisa em Ciências Humanas e Sociais. São Paulo: Cortez, 2003.

DANTO, A. C. Após o Fim da Arte: a arte contemporânea e os limites da história. São Paulo: Odysseus Editora, 2006.

D'OLIVEIRA, F. Geração 80: símbolos e mitos na pintura de Beatriz Milhazes. Diário de Pernambuco, Recife, 3 nov. 1989.

DRUMMOND, K. The migration of art from museum to Market: Consuming Caravaggio. Marketing Theory, v. 6, n. 1, p. 85-105, 2006.

ENCICLOPÉDIA ITAÚ CULTURAL DE ARTE E CULTURA BRASILEIRAS. Como Vai Você, Geração 80? São Paulo: Itaú Cultural, 2020. Disponível em: http://enciclopedia.itaucultural.org.br/evento83465/como-vai-voce-geracao-80. Acesso em: 30 set. 2020. 
ESCOLA DE ARTES VISUAIS DO PARQUE LAGE. Charles Watson: cursos do professor. Disponível em: http://eavparquelage.rj.gov.br/a-escola/professores/cursos-doprofessor/?prof $=28$. Acesso em: 30 set. 2020.

FARIAS, A. A. C. (Curadoria). 80/90, modernos, pós-modernos etc. São Paulo: Instituto Tomie Ohtake, 2009.

FIALHO, A. L. (Coord.). Pesquisa Setorial Latitude: o mercado de arte contemporânea no Brasil. 3. ed. São Paulo: ABACT; APEX-Brasil; Projeto Latitude. Disponível em: http://media.latitudebrasil.org/uploads/arquivos/arquivo/relatorio_por- 1.pdf. Acesso em: 30 set. 2020.

FIALHO, A. L. O Mercado da Arte Brasileira no Exterior. 3. ed. 28 jan. 2015. Disponível em: https://pt.scribd.com/doc/13092952/Tropico-O-Mercado-Da-Arte-Brasileira-NoExterior-Ana-Leticia-Fialho. Acesso em: 30 set. 2020.

FILLIS, I. Being creative at the marketing/entrepreneurship interface: lessons from the art industry. Journal of Research in Marketing and Entrepreneurship, v. 2, n. 2, p. 125-137, 2000.

FINDLAY, M. The Value of Art: money, power, beauty. New York: Prestel, 2012.

GAZETA DO POVO. Tela de Beatriz Milhazes é vendida por 16 milhões. São Paulo, 07 abr. 2016. Disponível em: https://www.gazetadopovo.com.br/caderno-g/artes-visuais/telade-beatriz-milhazes-e-vendida-por-r-16-milhoes-dvqzrgri0a2sjc77b8d3mzwd0/. Acesso em: 30 set. 2020 .

GRIMAL, P. The Dictionary of Classical Mythology. Londres: Wiley-Blackwell, 1996.

HARGREAVES MCINTYRE, M. Taste Buds: how to cultivate the art market. London: Art Council England, Oct. 2004.

HELMING, B.; HUBER, J.; LEEFLANG, P.S.H. Co-branding: the state of the art. SBR, 359-377, October 2008.

HERKENHOFF, P. Também para a "Geração 80", a alegria é a prova dos nove. Folha de $S$. Paulo, São Paulo, p. 26, 11 set. 1984.

HERKENHOFF, P.; PEDROSA, A. XXIV Bienal de São Paulo. São Paulo: Fundação Bienal, 1998.

HERKENHOFF, P. Beatriz Milhazes: cor e volúpia. Rio de Janeiro: Editora Francisco Alvez, 2007.

HOROWITZ, N. Art of the Deal: contemporary art in a global financial market. New York: Princeton University Press, 2014.

JORDÃO, L. (Coord.). Pesquisa Setorial Latitude: o mercado de arte contemporânea no Brasil. 4. ed. São Paulo: ABACT, APEX Brasil, 2018. 
KATO, G. O ritual do sucesso. Revista Bravo!, dezembro 2001.

KOTLER, P. Administração de Marketing: a edição do novo milênio. 10. ed. São Paulo: Prentice Hall, 2000.

LINDERMANN, A. Coleccionar Arte Contemporáneo. Madrid: Taschen, 2011.

LIPOVETSKY, G. A Estetização do Mundo: viver na era do capitalismo artista. São Paulo: Companhia das Letras, 2014.

MARTI, S. Tela de Beatriz Milhazes é vendida por R\$ 16 milhões na abertura da SP-Arte. Folha de S. Paulo, São Paulo, 6 abril 2016. Disponível em: https://www1.folha.uol.com.br/ilustrada/2016/04/1758353-tela-de-beatriz-milhazes-evendida-por-r-16-milhoes-na-abertura-da-sp-arte.shtm. Acesso em: 30 set. 2020.

MARTINHO, T. Quero ser livre. Revista TPM, p. 20-28. São Paulo: Editora Abril, agosto, 2013.

McANDREW, C. Art Economics: An Art Basel and UBS Report. Dundrum, Ireland, 2019.

MILHAZES, B. Mares do Sul. Curadoria Adriano Pedrosa. Trad. de Izabel Murat Burbridge, Michael Asburg, Odile Cisneros. Rio de Janeiro: Centro Cultural Banco do Brasil, 2002.

MORAIS, F. Anos 80: A pintura resiste. In: INSTITUTO ITAÚ CULTURAL (Org.) BR 80: Pintura Brasil Década de 80. São Paulo: Instituto Itaú Cultural, 1991.

MORESCHI, B. Abre alas que lá vem bolo-de-rolo. Revista Piauí, São Paulo, n. 32, maio 2009. Disponível em: http://piaui.folha.uol.com.br/materia/abre-alas-que-la-vem-bolo-derolo/. Acesso em: 25 jun. 2020.

NORRIS, M.; FINE, G. A. Marketing artistic careers: Pablo Picasso as brand manager. European Journal of Marketing, v. 48, n. 1/2, p. 68-88, 2014.

OLIVEIRA, R. A. Bienal de São Paulo: impacto na cultura brasileira. São Paulo em Perspectiva, v. 15, n. 3, junho/set. 2001. Disponível em: https://doi.org/10.1590/S010288392001000300004. Acesso em: 30 set. 2020.

PINHO, D. Arte como Investimento: a dimensão econômica da pintura. São Paulo, Nobel, EDUSP, 1989.

POWNALL, R. A. J. (Org.). TEFAF Art Market Report 2017. The Netherlands: The European Fine Art Foundation, 2018.

PREECE, C.; KERRIGAN, F. Multi-stakeholder brand narratives: an analysis of the construction of artistic brands. Journal of Marketing Management, v. 31, p. 11-12, 2015. Disponível em: https://doi.org/10.1080/0267257X.2014.997272. Acesso em: 30 set. 2020.

REITLINGER, G. The Economics of Taste: The Rise and Fall of Picture Prices, 1760-1960. London: Barrie and Rockliff, 1961. 
ROBERTSON, I.; CHONG, D. The Art Business. Abingdon: Routledge, 2005.

RODNER, V.; THOMSON, E. The art machine: dynamics of a value generating mechanism for contemporary art. Arts marketing: An Internatinal Journal, v.3, n. 1, p. 58-72, 2013.

RUBIM, A.; PITOMBO, M.; RUBIM, I. Políticas e Redes de Intercâmbio e Cooperação em Cultura no Ambito Ibero-Americano. Salvador, BA: Cátedra de Integração Andrés Bello, novembro 2005.

SCHROEDER, J. E. The artist and the brand. European Journal of Marketing, v. 39, n. 11/12, p. 1291-1305, 2005.

SMITH, R. Art in Review. The New York Times, sessão C, p. 27, March 22, 1996.

TALKING GALLERIES. Barcelona Symposium 2013: screen projects. Barcelona, 2014.

TALKING GALLERIES. Barcelona Symposium 2015: screen projects. Barcelona, 2016.

THOMPSON, D. O Tubarão de 12 Milhões de Dólares. São Paulo: Bei, 2011.

THOMPSON, D. The Supermodel and the Brillo Box: the back stories and peculiar economics from the world of contemporary art. New York: Palgrave MacMillan, 2014.

THORNTON, S. Seven Days in the Art World. New York: W. W. Norton \& Company, 2009.

TRIGO, L. A Grande Feira: uma reação ao vale-tudo na arte contemporânea. Rio de Janeiro: Civilização Brasileira, 2009.

TOWSE, R. A. Handbook of Cultural Economics. Cheltham, UK: Edward Elgar, 2011.

VOGEL, C. The Gray Areas of Jasper Johns. New York Times, p. 32, February 3, 2008, Arts and Leisure sec. 


\section{APÊNDICES}

\section{Apêndice A - Roteiro Entrevista com a artista}

Primeiramente, digamos que uma pessoa que não conheça seu trabalho e perguntasse a você sobre ele: como você o descreveria? não apenas as suas obras, mas todo o trabalho que engloba ser artista.

\section{Tratando agora do começo da carreira da artista:}

No início de sua carreira, como foi a recepção de suas obras por críticos e curadores?

Em que momento você sentiu que precisava aliar-se à galerias de arte para a difusão do seu trabalho? Como foi essa tomada de decisão?

Ainda no começo de sua carreira, como era feita a escolha de quais mostras participar e quais obras seriam vendidas?

\section{No decorrer da carreira da artista:}

Em que momento você sentiu que seu trabalho havia se legitimado perante o sistema da arte? Como foi esse momento?

Conforme essa legitimação ocorria, como você avalia que ocorreu a difusão de suas obras? Tanto na mídia como entre colecionadores, curadores e o público.

No processo de internacionalização de suas obras, como foi feita a escolha de associação com galerias fora do país?

\section{Pensando agora em termos de mercado:}

Como você avalia a sua produção no mercado nacional?

E no mercado internacional?

Em termos dos valores das obras para além do comercial, como o valor social difusão das obras pelos agentes do aparato das artes, tais como curadores, críticos, mídia especializada, galeristas, colecionadores) e o essencial os conceitos intrínsecos nas obras e como essas obras atingem cada indivíduo), como você percebe estes valores?

\section{Em termos de perspectivas atuais e futuras:}

Como você percebe o mercado de arte atual como um todo? E quais as perspectivas futuras para esse mercado?

Qual sua apreciação sobre o mercado em termos da sua carreira no momento? E para os próximos anos? 


\section{Apêndice B - Roteiro de Entrevista com agente do sistema}

Primeiramente, quando eu digo Beatriz Milhazes, o que lhe vem à mente? (Como artista contemporânea, como pessoa, como profissional?

Digamos que uma pessoa que não conheça a Beatriz, perguntasse a você sobre ela: Como a definiria no contexto contemporâneo brasileiro? E pensando no mercado internacional?

Quando e em quais circunstâncias você conheceu a artista Beatriz Milhazes? [EXPLORAR: se teve indicação de terceiros: quem indicou, ]

Desde quando trabalha com a Beatriz? Quais trabalhos já fez para ela?

Quais foram as suas primeiras impressões da artista?

Qual foi o argumento que você utilizou para inseri-la pela primeira vez nas suas curadorias?

\section{Tratando agora do começo da carreira da artista:}

Você ouviu alguma fala proferida por ela? E o que achou?

Você ouviu alguém falando sobre ela? O que abordavam?

Considerando as suas participações nas instituições de arte, como você percebia a recepção das obras da artista nesses locais no início de sua carreira?

\section{No decorrer da carreira da artista:}

Como você tem acompanhado as evoluções de sua carreira?

Como avalia que a sua participação nessa evolução da carreira da artista?

Como você percebe a reação do mercado como um todo em relação aos textos e exposições que você já fez sobre a artista? Em que medida, você pensa que auxiliaram a legitimar essa artista no sistema de arte?

Considerando as suas participações nas instituições de arte, como você percebe a recepção das obras da artista nesses locais?

\section{Pensando agora em termos de mercado:}

Você já conversou e/ou foi consultado por colecionadores de arte sobre as obras da artista? Como define o mercado de colecionadores de arte interessados em Beatriz Milhazes?

Como você avalia a relação dos colecionadores de arte com a artista?

E por galerias?

E por museus? Etc. 
Como você avalia a produção da artista no mercado nacional?

Você já teve solicitações de agentes do mercado de arte para colocá-la em exposições? Quais foram esses agentes?

Você já teve solicitações de agentes do mercado de arte para colocá-la em seus textos? Quais foram esses agentes?

\section{Em termos de perspectivas atuais e futuras:}

Como você percebe o mercado de arte atual como um todo? E quais as perspectivas futuras para esse mercado?

Qual sua apreciação sobre o mercado em termos da carreira da artista no momento? E para os próximos anos? 


\section{ANEXOS SOBRE BEATRIZ MILHAZES}

\section{Anexo A - Exposições Individuais}

2019

- Benesse House, Naoshima, Japan.

\section{8}

- Rio Azul, White Cube Bermondsey, London, UK.

\section{7}

- Marola, Mariola e Marilola, Carpintaria, Rio de Janeiro, Brasil.

- Um Itinerário Gráfico, SESC Morada do Baís, Campo Grande, Brasil.

\section{6}

- Galerie Max Hetzler, Berlin, Germany.

- Um Itinerário Gráfico, SESC Paraty, Paraty, Brasil.

\section{5}

- Coleção de Motivos, Espaço Cultural Unifor, Universidade de Fortaleza/Fundação Edson Queiroz, Fortaleza, Brasil.

- Marola, James Cohan Gallery, New York, USA.

- White Cube, Hong Kong.

- Um itinerário gráfico, SESC Iracema, Fortaleza; SESC Garanhuns, Garanhuns, Brasil.

\section{4}

- Jardim Botânico, Pérez Art Museum Miami, Miami, USA.

- Um itinerário gráfico, SESC Cabo Branco, João Pessoa, Brasil. 
- Meu Bem, Paço Imperial, Rio de Janeiro; Museu Oscar Niemeyer, Curitiba, Brasil.

- O Círculo e seus amigos, Galeria Fortes Vilaça, São Paulo, Brasil.

- Um itinerário gráfico, SESC São Carlos, São Carlos; SESC Bauru, Bauru, Brasil.

2012

- Panamericano, MALBA - Museo de Arte Latinoamericano de Buenos Aires, Buenos Aires, Argentina.

- Four Seasons, Fundação Calouste Gulbenkian, Lisboa, Portugal.

- Beatriz Milhazes: Gravuras - Acervo Pinacoteca do Estado de São Paulo, Caixa Cultural Rio de Janeiro, Rio de Janeiro, Brasil.

\section{1}

- Beatriz Milhazes, Screenprints 1996 - 2011, Whitechapel at Windsor, Miami, USA.

- Galerie Max Hetzler, Berlin, Germany.

- Fondation Beyeler, Basel, Switzerland.

\section{0}

- Stephen Friedman Gallery, London, UK.

- Beatriz Milhazes: Gravuras, Museu de Arte do Espírito Santo Dionísio Del Santo (Maes), Espírito Santo, Brasil.

2009

- Fondation Cartier pour l'art contemporain, Paris, France.

\section{8}

- Beatriz Milhazes - Pinturas e Colagens, Pinacoteca do Estado de São Paulo, São Paulo, Brasil.

- James Cohan Gallery, New York, USA.

- Galeria Fortes Vilaça, São Paulo, Brasil. 
- Beatriz Milhazes, New Prints, James Cohan Gallery, New York, USA.

\section{6}

- Pipoca Moderna, Galerie Max Hetzler, Berlin, Germany.

\section{5}

- Joá, Stephen Friedman Gallery, London, UK.

- Lagoa, MAP - Museu de Arte da Pampulha, Belo Horizonte, Brasil.

\section{4}

- Meu Prazer, Galeria Fortes Vilaça, São Paulo, Brasil.

- Summertime, James Cohan Gallery, New York, USA.

- The Encounters in the 21st Century: Polyphony - Emerging Resonances, 21st Century Museum of Contemporary Art, Kanazawa, Japan.

2003

- Domaine de Kerguéhennec, Centre d'Art Contemporain, Bignan, France.

- Galerie Max Hetzler, Berlin, Germany.

2002

- Mares do Sul, Centro Cultural Banco do Brasil, Rio de Janeiro, Brasil.

- Stephen Friedman Gallery, London, UK.

- Coisa Linda, Artist's Book Project, MoMA - Museum of Modern Art, New York, USA.

- Ikon Gallery, Birmingham, UK.

- Birmingham Museum of Art, Alabama, USA.

- Galeria Pedro Cera, Lisboa, Portugal.

- Galeria Elba Benitez, Madrid, Spain. 
- Galeria Camargo Vilaça, São Paulo, Brasil.

- Edward Thorp Gallery, New York, USA.

1999

- Screenprints, Durham Press, Durham, USA.

- Stephen Friedman Gallery, London, UK.

1998

- Galerie Natalie Obadia, Paris, France.

- Gravuras, Paço Imperial, Rio de Janeiro, Brasil.

- Pinturas, Galeria Ana Maria Niemeyer, Rio de Janeiro, Brasil.

1997

- Galerie Barbara Farber, Amsterdam, Netherlands.

- Galeria Elba Benitez, Madrid, Spain.

- Edward Thorp Gallery, New York, USA.

1996

- Galeria Camargo Vilaça, São Paulo, Brasil.

- Centro de Artes Calouste Gulbenkian, Rio de Janeiro, Brasil.

- Edward Thorp Gallery, New York, USA.

1995

- Projeto FINEP, Paço Imperial, Rio de Janeiro, Brasil.

- Dorothy Goldeen Gallery, Los Angeles, USA.

1994

- Paço Imperial, Rio de Janeiro, Brasil.

- Galeria Anna Maria Niemeyer, Rio de Janeiro, Brasil.

- Galeria Ramis Barquet, Monterrey, Mexico. 
1993

- Galeria Camargo Vilaça, São Paulo, Brasil.

- Sala Alternativa, Caracas, Venezuela.

1991

- Subdistrito Comercial de Arte, São Paulo, Brasil

1990

- Galeria Saramenha, Rio de Janeiro, Brasil.

1989

- Pasárgada Arte Contemporânea, Recife, Brasil.

\section{8}

- Galeria Suzana Sassoum, São Paulo, Brasil.

\section{7}

- Galeria César Aché, Rio de Janeiro, Brasil.

\section{5}

- Galeria César Aché, Rio de Janeiro, Brasil. 


\section{Anexo B - Exposições Coletivas}

\section{9}

- Passado/futuro/presente: arte contemporânea brasileira no acervo do MAM, MAM Museu de Arte Moderna de São Paulo, São Paulo, Brasil.

\section{8}

- Géométries Sud, Du Mexique à la Terre de Feu, Fondation Cartier pour l'art Contemporain, Paris, France.

- MACS Fora de Casa: Poéticas do Feminino, SESC Sorocaba, Sorocaba.

- Memory Palace, White Cube, London, UK.

- Remembering Tomorrow: Artworks and Archives, White Cube, Hong Kong, China.

- A Beautiful Elsewhere, Fondation Cartier pour l'art contemporain, Power Station of Art, Shanghai.

- Grids, James Cohan Gallery, New York, USA.

- Mulheres da Coleção MAR, MAR Museu de Arte do Rio, Rio de Janeiro, Brasil.

\section{7}

- Vanishing Points, James Cohan Gallery, New York, USA.

- Roberto Burle Marx: Brazilian Modernist, Kunsthalle by Deutsche Bank, Berlin, Germany.

- Past/Future/Presente: Contemporary Brazilian Art from the Museum of Modern Art, São Paulo, Phoenix Museum of Art, Phoenix, USA.

- Coleções do MAM, Museu de Arte Moderna de Resende, Resende, Brasil.

- Yes, nós temos biquínis, Centro Cultural Banco do Brasil, Rio de Janeiro, Brasil.

- Coleção MAC Niterói: Arte Contemporânea no Brasil, MAC Niterói, Niterói, Brasil.

- Um século de Arte Brasileira na Coleção da Fundação Edson Queiroz, Casa de Cultura de Sobral, Sobral, Brasil.

\section{6}

- Tertúlia, Galeria Fortes Vilaça, São Paulo, Brasil. 
- A Cor do Brasil: de Visconti a Volpi, de Sued a Milhazes, Museu de Arte do Rio, Rio de Janeiro, Brasil.

- Os muitos e o um, Instituto Tomie Ohtake, São Paulo, Brasil.

- Em Polvorosa - Um panorama da coleção do MAM Rio, MAM - Museu de Arte Moderna do Rio de Janeiro, Rio de Janeiro, Brasil.

- Clube de Gravura - 30 Anos, MAM - Museu de Arte Moderna de São Paulo, São Paulo, Brasil.

- Roberto Burle Marx: Brazilian Modernist, The Jewish Museum, New York, USA.

\section{5}

- Beauty Reigns: A Baroque Sensibility in Recent Painting, Akron Art Museum, Akron, USA.

- Alimentário, Arte e Construção do Patrimônio Alimentar Brasileiro, OCA - Pavilhão Lucas Nogueira Garcez, São Paulo, Brasil; Brazilian Pavillion at Expo Milano 2015, Milan, Italy.

- Uma Coleção Particular - Arte Contemporânea no Acervo da Pinacoteca, Pinacoteca do Estado de São Paulo, São Paulo, Brasil.

- Southern Exposure: 5 Brazilian Artists, Galerie Maximillian, Aspen, USA.

- Artists For Ikon, Ikon Gallery, Birmingham, UK.

- Apreensões e Objetos do Desejo: obras doadas pela Receita Federal ao MNBA, Museu Nacional de Belas Artes, Rio de Janeiro, Brasil.

- Geração 80: ousadia \& afirmação, Simões de Assis Galeria de Arte, Curitiba, Brasil.

- $10^{\mathrm{a}}$ Bienal do Mercosul, Mesagens de uma nova América, Porto Alegre, Brasil.

- Grace Farms Art Project, The Grace Farms Foundation, New Canaan, USA.

\section{4}

- Cruzamentos: Contemporary Art in Brazil, Wexner Center for the Arts, Ohio, USA.

- 140 Caracteres, MAM Museu de Arte Moderna de São Paulo, São Paulo, Brasil.

- A Tara por Livros ou a Tara de Papel, Galeria Bergamin, São Paulo, Brasil.

- Inventário da Paixão, Museu Histórico Nacional, Rio de Janeiro, Brasil.

- Unbound: Contemporary Art After Frida Kahlo, Museum of Contemporary Art Chicago, Chicago, USA. 
- Vivid Memories, Fondation Cartier, Paris, France.

- Cool Place. Scharpff Collection, Kunstmuseum Stuttgart, Stuttgart, Germany.

- Histórias Mestiças, Instituto Tomie Ohtake, São Paulo, Brasil.

- Abstrações - Coleção Fundação Edson Queiroz e Coleção Roberto Marinho, Espaço Cultural Unifor - Universidade de Fortaleza, Fortaleza, Brasil.

- Alimentário, Arte e Construção do Patrimônio Alimentar Brasileiro, MAM - Museu de Arte Moderna do Rio de Janeiro, Rio de Janeiro, Brasil.

- Beauty Reigns: A Baroque Sensibility in Recent Painting, McNay Art Museum, San Antonio, USA.

\section{3}

- Do Moderno ao Contemporâneo na Coleção Mineira, Museu Inimá de Paula, Belo Horizonte, Brasil.

- Trajetórias - Arte Brasileira na Coleção Fundação Edson Queiroz, Fundação Edson Queiroz, Fortaleza, Brasil.

- 30x Bienal, Fundação Bienal de São Paulo, São Paulo, Brasil.

\section{2}

- Mulheres nas coleções João Sattamini e MAC de Niterói - Museu de Arte Contemporânea de Nitererói, Niterói, Brasil.

- Gravura Brasileira no acervo da Pinacoteca de São Paulo - 100 Anos de História, Pinacoteca do Estado de São Paulo, São Paulo, Brasil.

- Joailier des Arts, Fondation Cartier pour l'Art Contemporain, Paris, França.

- Eco Art, Centro Municipal de Cultura Dr. Henrique Ordovás Filho, Caxias do Sul, Brasil.

- Coleção BGA, MUBE - Museu Brasileiro da Escultura, São Paulo, Brasil.

- Anna Maria Niemeyer, um caminho, Paço Imperial, Rio de Janeiro, Brasil.

\section{1}

- Mathématiques, un dépaysement soudain, Foundation Cartier pour l'Art Contemporain, Paris, França.

- Vestígios de Brasilidade, Santander Cultural, Recife, Brasil. 
- Ordem e Progresso, MAM - Museu de Arte Moderna de São Paulo, São Paulo, Brasil.

- Gigante pela própria natureza, IVAM- Instituto Valenciano de Arte Moderno, Valencia, Spain.

- Mulheres, Artistas e Brasileiras, Palácio do Planalto, Praça dos Três Poderes, Brasília, Brasil.

2010

- Forma (ação) gráfica a experiência, Escola de Artes Visuais do Parque Lage, Rio de Janeiro, Brasil.

- 40, Galeria Texas, Houston, USA.

- Banners of Persuasion. Demons, Yarns \& Tale: Tapestries by Contemporary Artists, Galeria James Cohan, New York, USA.

- Festival Internacional de Jardins de Chaumont-sur-Loire - Festival de Jardins do MAM, MAM - Museu de Arte Moderna de São Paulo, São Paulo, Brasil.

2009

- When Lives Become Form: Creative Power from Brazil, Hiroshima City Museum of Contemporary Art, Japan.

- Yerba Buena Center for the Arts, San Francisco, USA.

- Matisse Hoje / Aujourd'hui, Pinacoteca do Estado de São Paulo, São Paulo, Brasil.

- Desenhos [Drawings]: A - Z, Museu da Cidade, Lisboa, Portugal.

- Contemporary Tapestries, The Asian Pacific Contemporary Art Fair, Shanghai Exhibition Center, Shangai, China.

- Era uma vez... arte conta histórias do mundo, Centro Cultural Banco do Brasil, São Paulo, Brasil.

\section{8}

- Prospect.1 New Orleans Biennial, Louisiana State Museum, New Orleans, USA.

- Quando Vidas se Tornam Forma, MAM - Museu de Arte Moderna de São Paulo, São Paulo, Brasil. 
- When Lives Become Form: Creative Power from Brazil, Museum of Contemporary Art Tokyo (MOT), Tokyo, Japan.

- Tropics, Martin-Gropius-Bau, Berlin, Germany.

- Arte Contemporânea Brasileira - Doação Credit Suisse, Estação Pinacoteca, São Paulo, Brasil.

- Order.Desire.Light: An Exhibition of Contemporary Drawings, IMMA - Irish Museum of Modern Art, Dublin, Ireland.

- Demons, yarns \& tales, tapestries by contemporary artists, The Dairy, London, UK.

- Geografias (in) visibles - Contemporary Latin-American Art, Coleção Patrícia Phelps, Centro Cultural.

- Eduardo Leon Jimenes, Santiago de los Caballeros, Dominican Republic.

- Bordando Arte - Associação de Assistência à Criança Cardíaca e à Transplantada do Coração (ACTC), Pinacoteca do Estado de São Paulo, São Paulo, Brasil.

- Parkett's 25 Years Retrospective, 21st Century Museum of Contemporary Art, Kanazawa, Japan.

\section{7}

- 80-90: Modernos, Pós Modernos, Instituto Tomie Ohtake, São Paulo, Brasil.

- Um Século de Arte Brasileira, Coleção Gilberto Chateaubriand, Museu de Arte Moderna da Bahia, Salvador, Brasil.

- Itaú Contemporâneo - Arte no Brasil de 1981 a 2006, Itaú Cultural, São Paulo, Brasil

- What is Painting?, MoMA - Museum of Modern Art, Nova York, EUA.

- Cardinal Points/Puntos Cardinales: A Survey of Contemporary Latino and Latin American Art from Sprint Nextel Art Collection, Mid-America Arts Alliance, Kansas City, EUA.

- Exposição comemorativa de 70 anos do IPHAN, Paço Imperial, Rio de Janeiro, Brasil.

- PostDec - Beyond Pattern a Decoration, Galeria Joseloff, Hartford Art School, University of Hartford, New York, EUA.

- Pintura Brasileira no acervo do MAM-SP, Museu de Arte do Espírito Santo Dionísio Del Santo, Vitória, Brasil. 
- Shangai Biennale, Shangai Art Museum, Shangai, China.

- Between Art and Life: The Contemporary Painting and Sculpture Collection, SFMoMA - San Francisco Museum of Modern Art, San Francisco, USA.

- É HOJE na arte brasileira contemporânea - Coleção Gilberto Chateaubriant, Centro Cultural Santander Banespa, Rio de Janeiro, Brasil.

- Dear Friends, Domaine de Kerguéhennec, Centre d'Art Contemporain, Bignan, France.

- POPulence, Southeastern Center for Contemporary Art, Winston-Salem, USA.

- Sem Título, 2006 Comodato Eduardo Brandão e Jan Fjeld, MAM - Museu de Arte Moderna de São Paulo, São Paulo, Brasil.

- Since 2000: Printmaking Now, Print Galleries - MoMA, The Museum of Modern Art, New York, USA.

- Off the self: New forms in contemporary artist' book, Frances Lehman Loeb Art Center, Vassar College, Poughkeepsie, New York, USA.

- Deuses Gregos em Templos Contemporâneos, MAC - Museu de Arte Contemporânea de Niterói, Niterói, Brasil.

- Manobras Radicais: Artistas Brasileiras [1886-2005], Centro Cultural Banco do Brasil, São Paulo, Brasil.

- MAM[NA]OCA - Arte Brasileira no acervo do Museu de Arte Moderna de São Paulo, MAM - Museu de Arte Moderna de São Paulo, São Paulo, Brasil.

\section{5}

- Flower Myth - Van Gogh to Jeff Koons, Foundation Beyeler, Basel, Switzerland.

- POPulence, Blaffer Gallery - The Art Museum of The University of Houston, Texas, USA.

- $24^{\mathrm{a}}$ Arte Pará 2005 Contemporâneo, Fundação Rômulo Maiorana, Belém, Brasil.

- Works on paper, Galerie Max Hetzler, Berlin, Germany.

- Tenth Anniversary Exhibition, Stephen Friedman Gallery, London, UK. 
- OPTIMO: Manifestations of Optimism in Contemporary Art, Ballroom Marfa, Texas, USA.

- MoMA at El Museo: Latin American and Caribbean Art from the Collection of The Museum of Modern Art, Museo del Barrio, New York, USA.

- XXVI Bienal de São Paulo, Fundação Bienal de São Paulo, São Paulo, Brasil.

- Carnaval, Centro Cultural Banco do Brasil, Rio de Janeiro, Brasil.

- Ice Hot: Recent Painting from the Scharpff Collection, Hamburger Kunstalle, Hamburg, Germany.

- Estratégias Barrocas - Arte Contemporânea Brasileira, Centro Cultural Metropolitano de Quito, Quito, Equador.

- Onde está você Geração 80?, Centro Cultural Banco do Brasil, Rio de Janeiro; Centro Cultural Banco do Brasil, Brasília, Brasil.

- Flower as Image - From Monett to Jeff Koons, Louisiana Museum, Humlebæk, Denmark.

- Arte Contemporânea Brasileira nas Coleções do Rio, MAM -Museu de Arte Moderna do Rio de Janeiro, Rio de Janeiro, Brasil.

- Paralela 2004, São Paulo, Brasil.

- Between The Lines, James Cohan Gallery, New York, USA.

- Natureza-Morta/Still Life, Galeria de Arte do Centro Cultural SESI, São Paulo, Brasil.

\section{3}

- 50a Biennale di Venezia, Pavilhão brasileiro, Venice, Italy.

- 2080, MAM - Museu de Arte Moderna de São Paulo, São Paulo, Brasil.

\section{2}

- Urgent Painting, Musée d'Art Moderne de la Ville de Paris, Paris, France.

- Metrópolis, Pinacoteca do Estado de São Paulo, São Paulo, Brasil.

- Caminhos do Contemporâneo, Paço Imperial do Rio de Janeiro, Rio de Janeiro, Brasil. 
- Polly Appfelbaum, Black Flag Beatriz Milhazes, D'Amelio Terras Gallery, New York, USA.

- O Mapa do Agora - Coleção João Sattamini, Instituto Tomie Ohtake, São Paulo, Brasil.

2001

- Rotativa Fase 1, Galeria Fortes Vilaça, São Paulo, Brasil.

- Hybrids, Tate Liverpool, Liverpool, UK.

- Airport Fine Arts, Miami, USA.

- Posters of the Years to Come, Artware AG, Vienna, Austria.

- Viva a Arte Brasileira, MAM - Museu de Arte Moderna do Rio de Janeiro, Rio de Janeiro, Brasil.

- Amigos da Gravura, Museu da Chácara do Céu, Rio de Janeiro, Brasil.

- Operativo, Museu Rufino Tamayo, Mexico City, Mexico.

- Trajetória da Luz, Instituto Itaú Cultural, São Paulo, Brasil.

- Espelho Cego, MAM - Museu de Arte Moderna de São Paulo, São Paulo; Paço Imperial, Rio de Janeiro, Brasil.

- Cultura Brasileira 1, Casa das Rosas, São Paulo, Brasil.

2000

- Projects 70, MoMA - Museum of Modern Art, New York, USA.

- Opulent, Cheim \& Read Gallery, New York, USA.

- Universal Abstraction 2000, Jan Weiner Gallery, Kansas City, USA.

- A Imagem do Som de Chico Buarque, Paço Imperial, Rio de Janeiro, Brasil.

- XII Mostra da Gravura da Cidade de Curitiba, Curitiba, Brasil.

- Posters of the Years to Come, Artware AG, Vienna, Austria.

- F(r)icciones, Museo Nacional Centro de Arte Reina Sofia, Madrid, Spain.

- Drawings, Stephen Friedman Gallery, London, UK.

- Furnished Paintings, Galeria OMR, Mexico D.F., Mexico.

- Rosas Rosas, Casa das Rosas, São Paulo, Brasil. 
- Objetos Anos 90, Instituto Itaú Cultural, São Paulo, Brasil.

- Abstract Painting, Once Removed, Keemper Museum of Art, Kansas City, USA.

- Painting, Galerie Natalie Obadia, Paris, France.

- Recent Prints, Betsy Senior Gallery, New York, USA.

- Woman Printmakers, Jem Kempner Gallery, New York, USA.

- Impressões Contemporâneas, Mostra Rio Gravura, Paço Imperial, Rio de Janeiro, Brasil.

- Tansvanguarda Latino Americana, Culturgest, Lisboa, Portugal.

1998

- XXIV Bienal de São Paulo, Fundação Bienal de São Paulo, São Paulo, Brasil.

- XI Biennale of Sydney, Sydney, Australia.

- Hanging, Galeria Camargo Vilaça, São Paulo, Brasil.

- Salão Nacional de Artes, MAM - Museu de Arte Moderna do Rio de Janeiro, Rio de Janeiro, Brasil.

- Trio, Sala Alternativa, Caracas, Venezuela.

- Painting Language, L.A. Louver, Los Angeles, USA.

- Decorative Strategies, Center for Curatorial Studies Bard College, Annandale-onHudson, New York, USA.

- Abstract Painting, Once Removed, Contemporary Arts Museum, Houston, USA.

- Um Olhar Brasileiro, Coleção Gilberto Chateaubriand, Haus der Kulturen der Welt, Berlin, Germany.

- Os Anos 80, Marina Potrich Galeria de Arte, Goiânia, Brasil.

- Ludwig Forum Für Internationale, Kunst, Aachen, Germany.

- Group Show, Kunst Museum, Heidenheim, Germany.

- Camargo Vilaça Bis 46, Galeria Camargo Vilaça, São Paulo, Brasil.

- Durham Press - 10 Year Anniversary, Marcel Sitcoske Gallery, San Francisco, USA.

- Espelho da Bienal, MAC - Museu de Arte Contemporânea de Niterói, Niterói, Niteroi, Brasil. 
- Theories of the Decorative, Inverleith House, Edinburgh, Scotland.

- Desde el Cuerpo: Alegorias de lo Feminino, Museo de Bellas Artes, Caracas, Venezuela.

- New Editions and Works on Paper, Betsy Senior Gallery, New York, USA.

1996

- Ouro de Artista, Galeria Casa Triângulo, São Paulo, Brasil.

- Impressões Itinerantes, Palácio das Artes, Belo Horizonte, Brasil.

- Excesso, Paço das Artes, São Paulo, Brasil.

- Theories of the Decorative, Baumgartner Galleries Inc., Washington, USA.

- Iole, Milhazes, Duarte, Museo Alejandro Otero, Caracas, Venezuela.

- Brasil Contemporâneo, Casa da América Latina, Madrid, Spain.

- Pequenas Mãos, Paço Imperial, Rio de Janeiro; Centro Cultural Alumni, São Paulo, Brasil.

- Coleção João Sattamini, Museu de Arte Contemporânea de Niterói, Niterói, Brasil.

1995

- Regards d'Amerique Latine, Galerie Regard, Geneva, Switzerland.

- Carnegie International, The Carnegie Museum of Art, Pittsburgh, USA.

- Anos 80: O palco da diversidade, MAM - Museu de Arte Moderna do Rio de Janeiro, Rio de Janeiro; Galeria de Arte do Sesi, São Paulo, Brasil.

- Transatlântica - The America-Europa Non Representativa, Museo Alejandro Otero, Caracas, Venezuela.

- Galeria Camargo Vilaça, São Paulo, Brasil.

- Panorama da Atual Arte Brasileira, MAM - Museu de Arte Moderna de São Paulo, São Paulo; MAM - Museu de Arte Moderna do Rio de Janeiro, Rio de Janeiro, Brasil.

1994

- Pequeños Formatos Latinoamericanos, Luigi Marrozzini Gallery, San Juan, Porto Rico. 
- The Exchange Show: twelve painters from San Francisco and Rio de Janeiro, Center for the Arts Yerba Buena Gardens, São Francisco, USA.

- $\quad$ MAM - Museu de Arte Moderna do Rio de Janeiro, Rio de Janeiro, Brasil.

- Slant of Light, International Art Exhibition - Art New York International, New York, USA.

- Dialogo sobre Siete Puntos - Encuentro Interamericano de Artes Plásticas, Museo de Guadalajara, Guadalajara, Mexico.

1993

- A Escolha do Artista, Paço Imperial, Rio de Janeiro, Brasil.

- Gravuras, Espaço Namour, São Paulo, Brasil.

- Brasil Contemporâneo, Casa da Imagem, Curitiba, Brasil.

- Coleção Gilberto Chateaubriand, MAM - Museu de Arte Moderna do Rio de Janeiro, Rio de Janeiro, Brasil.

- A Caminho do Museu, Centro Cultural São Paulo, São Paulo, Brasil.

- Encontros e Tendências, MAC-USP Museu de Arte Contemporânea da Universidade de São Paulo, São Paulo, Brasil.

- Ultramodern, The Art of Contemporary Brasil, The National Museum of Women in the Arts, Washington DC, USA.

1992

- A Caminho do Museu - Coleção João Sattamini, Paço Imperial, Rio de Janeiro, Brasil.

- João Sattamini/Subdistrito, Casa das Rosas, São Paulo, Brasil.

- America, Sala Alternativa, Caracas, Venezuela.

- Eco-Arte, MAM - Museu de Arte Moderna do Rio de Janeiro, Rio de Janeiro, Brasil.

1991

- Brasil La Nueva Generación, Fundación Museo de Bellas Artes, Caracas, Venezuela.

- BR/80 - A Pintura dos Anos 80, Casa França-Brasil, Rio de Janeiro, Brasil. 
- Prêmio Brasília de Artes Plásticas, Museu de Arte de Brasília, Brasília, Brasil.

- O Rosto e a Obra, Galeria do Ibeu, Rio de Janeiro, Brasil.

- Projeto Árqueos, Fundição Progresso, Rio de Janeiro, Brasil.

1989

- Rio Hoje, MAM - Museu de Arte Moderna do Rio de Janeiro, Rio de Janeiro, Brasil.

- Canale, Fonseca, Milhazes, Pizarro, Zerbini, Museu de Arte Contemporânea, São Paulo; Museu Municipal de Arte, Curitiba, Brasil.

- O Mestre e a Mostra, Escola de Artes Visuais do Parque Lage, Rio de Janeiro, Brasil

- II Bienal Internacional de Cuenca, Cuenca, Equador.

\section{8}

- Subindo a Serra, Palácio das Artes, Belo Horizonte, Brasil.

- Dois a Dois, Galeria do Consulado-Geral da Argentina, Rio de Janeiro, Brasil.

- Salão Nacional de Artes Plásticas, Funarte, Rio de Janeiro, Brasil.

1987

- Salão Paulista de Arte Contemporânea, Pavilhão da Fundação Bienal, São Paulo, Brasil.

1986

- Bienal Latino Americana de Arte sobre Papel, Buenos Aires, Argentina.

- El Escrete Voador, Guadalajara, México.

- Território Ocupado, Parque Lage, Rio de Janeiro, Brasil.

- Novas Impressões, GB Arte, Rio de Janeiro, Brasil.

- 4 Pintores, Galeria de Arte UFF (Universidade Federal Fluminense), Niterói, Brasil.

\section{5}

- Salão Nacional de Artes Plásticas, MAM - Museu de Arte Moderna do Rio de Janeiro, Rio de Janeiro, Brasil.

- Arte Construção, Galeria do Centro Empresarial, Rio de Janeiro, Brasil. 
- Arte Jovem Internacional, Univerzíade, Kobe, Japão.

1984

- Como Vai Você Geração 80?, Escola de Artes Visuais do Parque Lage, Rio de Janeiro, Brasil.

- Arte na Rua, MAC-USP Museu de Arte Contemporânea da Universidade de São Paulo, São Paulo, Brasil.

- $7^{0}$ Salão Nacional de Artes Plásticas, MAM - Museu de Arte Moderna do Rio de Janeiro, Rio de Janeiro, Brasil.

1983

- Pintura, Pintura! Fundação Casa Rui Barbosa, Rio de Janeiro, Brasil.

- Salão Nacional de Artes Plásticas, MAM - Museu de Arte Moderna do Rio de Janeiro, Rio de Janeiro, Brasil. 


\section{Anexo C - Projetos Especiais}

\section{9}

- Yellow Flower Dream, A-Art House, Naoshima, Japan.

\section{8}

- NewYork-Presbiterian Hospital, New York, USA.

\section{6}

- Using Walls, Floors, and Ceilings, The Jewish Museum, New York, USA.

- Moon Love Dreaming, obra site-specific de caráter permanente instalada na [permanent site-specific work installed at] Grace Farm Foundation, New Canaan, USA.

\section{2}

- Jardim Verde, painel projetado para a [panel designed for the] Fundação Calouste Gulbenkian, Lisboa, Portugal.

\section{1}

- Aquarium, móbile projetado para o [mobile designed for the] Atelier Cartier \& Fondation Cartier pour l'Art Contemporain, Paris, France.

- Gamboa, móbile re-projetado para a [re-designed mobile for the] Fundação Beyeler, Basel, Switzerland..

\section{0}

- Arpoador, jardim concebido para o [garden designed for the] Festival de Jardins do Museu de Arte Moderna de São Paulo, São Paulo, Brasil.

- Saravá, fachada de vidro projetada para [glass façade designed for] Stephen Friedman, London, UK.

- Sol, cerâmica projetada para o chão da [ceramic designed for the floor of the] Beyeler Fundation, Basel, Switzerland. 


\section{9-10}

- American Seasons, pintura mural projetada para a [wall-painting designed for the] K \& L Gates Center, Pittsburgh, USA.

2009

- Casa de Baile e Samambaia, fachada de vidro projetada para a [glass façade designed for the] Fondation Cartier pour l'Art Contemporain, Paris, France.

\section{8}

- Bailinho, projeto concebido para as janelas da [project designed for the windows of the] Pinacoteca do Estado de São Paulo, São Paulo, Brasil.

- Maracolouco, projeto concebido para as janelas do [glass window designed for the] Museu de Arte Contemporânea de Tokyo, Japan.

- Gamboa, móbile projetado para a [mobile designed for] Prospect.1, Bienal New Orleans, New Orleans, USA.

\section{5-07}

- Guanabara, Restaurante do Nível 7 da [Level 7 Restaurant at] Tate Modern, London, UK.

\section{5-06}

- Paz e Amor, obra instalada em uma estação de metrô pelo projeto [work installed at a subway station for the project] Gloucester Road Station Project - Platform for Art, London, UK. 


\section{Anexo D - Coleções Públicas}

- 21 st Century Museum of Contemporary Art, Kanazawa, Japan.

- Birmingham Museum of Art, Birmingham, UK.

- Carnegie Museum of Art - Alexander C. and Tillie S. Speyer, Fund for Contemporary Art in honor of Madeleine Grynsztejn, Pittsburgh, USA.

- Coleção Berardo, Lisboa, Portugal.

- Fondation Beyeler, Basel, Switzerland.

- Fundação Edson Queiroz, Fortaleza, Brasil.

- Fundación La Caixa, Madrid, Spain.

- Instituto Itaú Cultural, São Paulo, Brasil.

- La Sacem Neuilly-Sur Seine, France.

- MAM - Museu de Arte Moderna de São Paulo, São Paulo, Brasil.

- MAM - Museu de Arte Moderna do Rio de Janeiro, Rio de Janeiro Brasil.

- Metropolitan Museum of Art, New York, USA.

- MNBA - Museu Nacional de Belas Artes, Rio de Janeiro, Brasil.

- MoMA - The Museum of Modern Art, New York, USA.

- Museo Nacional Centro de Arte Reina Sofia, Madrid, Spain.

- Museu de Arte Contemporânea de Niterói, Niterói, Brasil.

- Museu de Belas Artes, Caracas, Venezuela.

- Museum of Contemporary Art, Tokyo Art Museum, Tokyo, Japan.

- Pinacoteca do Estado de São Paulo, São Paulo, Brasil.

- SFMoMA - San Francisco Museum of Modern Art, San Francisco, USA.

- Solomon R. Guggenhein Museum, New York, USA.

- TBA21 - Thyssen- Bornemisza Art Contemporary, Vienna, Austria.

- The Bohen Fondation, New York, USA.

- Worcester Art Museum, Worcester, USA. 


\section{Anexo E - Livros e Catálogos}

\section{9}

- It speaks to Me: Art That Inspires Artists. New York: Prestel, 2018. Editado por Jori Finkel. Taschen: Limited Editions 2018-2019. Berlin: Taschen, 2019.

\section{8}

- Beatriz Milhazes: Colagens / Collages. Rio de Janeiro: Cobogó, 2018. Editado por Honey Luard, textos por Frédéric Paul e conversa com Glenn Brown.

- Beatriz Milhazes: Rio Azul. Londres: White Cube, 2018. Texto por Luiza Interlenghi.

- Contemporary Edition: Online Auction 9/17 Jul. New York: Christie's Catalogue, 2018.

- Marco Zero: artistas e seus estúdios. Rio de Janeiro: ArteEnsaio, 2018. Textos por Gustavo Malheiros e Lilian Tone.

\section{7}

- Art as Jewellery: From Calder to Kapoor. Suffolk: ACC Art Books, 2017. Texto por Louisa Kapoor.

- Beatriz Milhazes. Cologne: Taschen, 2017. Edited by Hands Werner Holzwarth, textos de David Ebony, Luiza Interlenghi e Adriano Pedrosa, conversa com Hans Werner Holzwarth.

- Past/Future/Present: Contemporary Brazilian Art. São Paulo: Museu de Arte Moderna. Phoenix: Phoenix Art Museum, 2017

\section{6}

- Clube da Gravura: 30 anos. São Paulo: Ministério da Cultura; Museu de Arte Moderna de São Paulo, 2016. Texto por Cauê Alves.

- Invasão Criativa: Cidade Matarazzo. São Paulo: Associação Feito por Brasileiros; Ipsis, 2016. Textos de Alexandre Allard, Cynthia Garcia, Gabriela Longman e Hermés Galvão. 
- Roberto Burle, Marx: Brazilian Modernist. New York: The Jewish Museum; New Haven, CT: Yale University Press, 2016. Editado por Jens Hoffman e Claudia J. Nahson.

- She: International Women Artists Exhibition. Shangai: Long Museum, 2016. Editado por Wang Wei.

- Manobras radicais: artistas brasileiras (1886-2005). São Paulo: Centro Cultural Banco do Brasil, 2016. Textos por Paulo Herkenhoff e Heloisa Buarque de Holanda.

\section{5}

- $\quad 10^{a}$. Bienal do Mercosul: Mensagem de uma Nova América. Porto Alegre: Fundação Bienal do Mercosul, 2015. Textos de Gaudêncio Fidelis, Jésica Jank, Márcio Tavares e Ana Zavadil.

- Artists for Ikon. Birmingham: Ikon Gallery, 2015. Texto por Jonathan Watkins.

- Beatriz Milhazes: Coleção de Motivos. São Paulo: Base 7 Projetos Culturais; Fortaleza: Espaço Cultural Unifor, 2015. Texto por Luiza Interlenghi.

- Histórias Mestiças. São Paulo: Instituto Tomie Ohtake; Rio de Janeiro: Cobogó, 2015. Textos por Adriano Pedrosa e Lilia Moritz Schwarcz.

- Museu Oscar Niemeyer. São Paulo: Banco Safra; Coleção Museus Brasileiros, 2015. Editado por Cristine Pieske e Marianna Camargo.

- The collection: 21st Century Museum of Contemporary Art, Kanazawa, Tóquio: My Book Service, 2015. Editado por Masatoshi Ito e Atsuki Kikuchi.

\section{4}

- 140 Caracteres. São Paulo: Museu de Arte Moderna de São Paulo, 2014. Texto por Felipe Chaimovich.

- Acervo em Plástico da Pinacoteca: Problemática de Conservação e Restauro. São Paulo: Pinacoteca do Estado de São Paulo, 2014. Editado por Luiz Vieira.

- Afetividades Efetivas: Coleção Luiz Sérgio Arantes. Belo Horizonte: Galeria de Arte do Centro Cultural Minas Tênia Clube, 2014. Textos por Margarida Sant'Anna e Luiz Sérgio Arantes.

- Alimentário Arte e Construção do Patrimônio Alimentar Brasileiro. Rio de Janeiro: Museu de Arte Moderna do Rio de Janeiro, 2014. Textos por Jacopo Crivelli Visconti, Felipe Ribenboim e Rodrigo Villela. 
- Beatriz Milhazes: Jardim Botânico. Miami: Pérez Art Museum Miami, 2014. Textos por Paulo Herkenhoff e Tobias Ostrander, conversas com Tanya Barson.

- Beauty Reigns: A baroque Sensibility in Recent Painting. San Antonio: McNay Art Museum, 2014. Textos por René Paul Barrilleaux, Lili Wei e Stephen Westfall.

- Coleção de Arte Museu de Valores. Brasília: Museu de Valores do Banco do Brasil, 2014. Texto por Fabio Magalhães e Maria Alice Milliet.

- Connecting Leaders: Dialogue. Dusserdörf: Egon Zehnder International, 2014. Editado por Ulrike Krause, conversas entre Beatriz Milhazes e Helion Bruck Rorenberg et. Al.

- Cruzamentos: Contemporary Art in Brazil. Columus: Wexner Center for the Arts; The Ohio State University, 2014. Editado por Jennifer Lange.

- Foundation Cartier: Trente ans pour l'art contemporain. 2 v. Paris: Foundation Cartier pour l'art contemporain, 2014.

- Gorgeous. San Francisco: Asian Art Museum, 2014.Editado por Allison Harding e Forrest McGill.

- Inventário da Paixão: Homenagem a Marcantonio Vilaça. Rio de Janeiro: Museu Histórico Nacional, 2014. Textos por Marcus de Lontra e Daniela Name.

- Nicola Erni Collection: Zeitgeist \& Glamour, Fashion: Big shots! Paitings, Installations. Suiça: Nicola Erni Collection, 2014. Textos por Florentine Rosemeyer e Ira Stehmann.

- Arte, Educação \& Gestão: 1982-2014. Fortaleza: Universidade de Fortaleza 2014. Textos por Chanceler Airton Queiroz.

- 33 Artists in 3 Acts. Londres: Granta, 2014. Textos por Sarah Thornton.

\section{3}

- 30 x Bienal: Transformações na Arte Brasileira da $1^{\mathrm{a}}$ a $30^{\mathrm{a}}$ Edição. São Paulo: Fundação Bienal, 2013. Textos por Paulo Venancio Filho.

- $A B C$ : Arte Brasileira Contemporânea. São Paulo: Cosac Naify, 2013. Editado por Adriano Pedrosa e Luisa Duarte.

- Arte contemporânea brasileira dos anos 1950 aos Dias Atuais. Fortaleza: Galeria Multiarte, 2013. Textos por Max Perlingeiro, Mario Pedrosa e Fernando Cocchiarale.

- Art Now 4. Cologne: Taschen, 2013. Editado por Hans Werner Holzwarth. 
- Beatriz Milhazes: Meu bem. Rio de Janeiro: Centro Cultural Paço Imperial; Curitiba: Museu Oscar Niemeyer, São Paulo: Base 7 Projetos Culturais, 2013. Textos por Frédéric Paul.

- Beatriz Milhazes. São Paulo: Coleção Folha Grandes Pintores Brasileiros, Folha de S. Paulo, 2013. Texto por Maria Carolina Duprat Ruggeri.

- Trajetórias: Arte Brasileira na Coleção Fundação Edson Queiros - Unifor 40 anos. Fortaleza: Espaço Cultural Unifor, 2013. Textos por Marcelo Campos e Paulo Herkenhoff.

\section{2}

- Anna Maria Niemeyer, um Caminho. Rio de Janeiro: Centro Cultural Paço Imperial, 2012. Texto por Lauro Cavalcanti.

- Beatriz Milhazes. Basel: Foundation Beyeler; Otsfildern: Hatje Cantz, 2012. Textos por Michiko Kono e Delfim Sardo.

- Beatriz Milhazes: Gravuras: Acervo Pinacoteca do Estado de São Paulo. Rio de Janeiro: Caixa Cultural; Tisara Arte Produções, 2012. Texto por Faye Hirsch.

- Beatriz Milhazes: Panamericano; Pinturas 1999-2012. Buenos Aires: Museu de Arte Latinoamericano; Fundación Constantini, 2012. Textos por Paulo Herkenhoff e Frédéric Paul, conversas com Christian Lacroix.

- Beatriz Milhazes: Snow in the Tropics. Milão: Electa, 2012. Texto por Frédéric Paul, convesas com Christian Lacroix e Frédéric Paul.

- Beatriz Milhazes um intinerário gráfico. Rio de Janeiro: Projeto Arte SESC, 2012. Texto por Luiza Interlenghi.

\section{1}

- A poesia é para Comer. São Paulo: Editora Babel, 2011. Texto por Ana Vidal.

- Arte contemporânea no Século XXI. Rio de Janeiro: Editora Capivara, 2011. Editado por Ricardo Sardenberg.

- Beatriz Milhazes. Berlin: Holzwarth Publications; Galerie Max Hetzler, 2011. Texto por Sebastian Preuss.

- Beatriz Milhazes: Screenprints 1996-2011. Londres, Whitechapel Gallery; Vero Beach, Windsor Press, 2011. Textos por Iwona Blazwick e Jean-Paul Russel, conversas com Arto Lindsay 
- Guia Coleção MALBA. Buenos Aires: Fundación Constantini, 2011. Textos por Cintia Mezza e Marcelo E. Pacheco.

- Mathématiques: Um Dépaysement soudain. Paris: Foundation Carties pour l'art contemporain, 2011.

- Modern Art. Cologne: Taschen, 2011. Editado por Hans Werner Holzwarth.

- Pintura Brasileira Séc XXI. Rio de Janeiro: Editora Cobogó, 2011. Editado por Frederico Coelho e Isabel Diegues.

- Pintura Contemporanea Latino Americana. Santiago de Chile: Celfin Capital, 2011. Texto de Edward Shaw.

- The Collection Catalogue of 21st Century Museum of Contemporary Art. Kanazawa, Tóquio: Bluemark, 2011.

- Vestígios de Brasilidade. Recife: Santander Cultural, 2011. Texto de Marcelo Campos.

\section{0}

- Anos 80: Embates de uma Geração. Rio de Janeiro: Editora Francisco Alves, 2010. Textos de Ligia Canongia, Frederico Morais, Adriana Varejão et al.

- Beggining of Dialogue or Post-collection. Kanazawa: 21st Century Museum of Contemporary, 2010. Texto por Misato Fudo.

- Brasil: Terra de todas as cores. São Paulo: Artebr, 2010. Texto de Daniel Nunes Gonçalves.

- Festival de Jardins do MAM no Ibirapuera. São Paulo Museu de Arte Moderna de São Paulo, 2010. Textos por Felipe Chaimovich e Chantal Colleu-Dumond.

- Forma (ação) gráfica: a experiência da EAV Parque Lage. Rio de Janeiro: Escola de Artes Visuais do Parque Lage, 2010. Texto de George Kornis.

- O Museu de Arte Contemporânea de Niterói: As coleções. Niterói: Museu de Arte Contemporânea de Niterói, 2010. Textos de Guilherme Bueno, Ítalo Campofiorito e Márcia Campos.

- Arte Brasileira nos Acervos de Curitiba. Curitiba: Editora Segesta, 2010. Textos de Daniela Vicentini e Fernando Burjjato.

- What 21st Century Museum of Contemporary Art of Kanazawa Aims to Achieve. Kanazawa: 21st Century Museum of Contemporary Art, 2010. Texto por Yujo Akimoto. 
- 100 Contemporary Artists. Cologne: Taschen, 2009. Editado por Hans Werner Holzwarth

- 200 Art Works 25 Years: Artists' Editions for Parkett. Zurique: Parquett, 2009. Textos por Susan Tallman e Deborah Wye.

- Arte e Ousadia: O Brasil na Coleção Sattamini. Rio de Janeiro: Aprasível Edições, 2009. Editado por Leonel Kaz e Nigge Loddi.

- Beatriz Milhazes. Paris: Fondation Cartier pour l'Art Contemporain, 2009. Conversas com Leanne Sacramone.

- Circuito Colecionador: Regina e Delcir da Costa. Belo Horitonte: Editora C/Arte, 2009. Editado por Fernando Pedro da Silva.

- Era uma vez...Arte Conta Histórias do Mundo. São Paulo: Centro Cultural Banco do Brasil, 2009. Texto por Katia Canton.

- Galeria de Arte Brasileira Moderna e Contemporânea. Rio de Janeiro: Museu Nacional de Belas Artes, 2009. Textos por Mariza Guimarães Diaz, Laura Maria Neves de Abreu e Pedro Martins Xexéo.

\section{8}

- Art Now 3. Cologne: Taschen, 2008. Editado por Hans Werner Holzwarth.

- Artworks: The Pogressive Collection. New York: D.A.P., 2008. Textos por Dan Cameron, Peter B. Lewis, Toni Morrison et al.

- Beatriz Milhazes: Pintura, colagem. São Paulo: Pinacoteca do Estado de São Paulo, 2008. Texts por Oswaldo Corrêa da Costa, Faye Hirsch e Ivo Mesquita.

- Clube da Gravura: a história do Clube de Colecionadores do MAM. São Paulo: Museu de Arte Moderna de São Paulo, 2008. Editado por Cauê Alves e Margarida Sant'Anna.

- Coleção Ana Luisa e Mariano Marcondes Ferraz. São Paulo: Trio Studio; Ipsis Gráfica e Editora, 2008. Textos por Mariano Marcondes Ferras, Ricardo Rego e Felipe Scovino.

- Arte Contemporanea Brazileña: Documentos y Criticas. Santiago de Compostella: Artedardo, 2008. Textos por Glória Ferreira. 
- Oder. Desire. Light: Na Exhibition of Contemporary Drawings. Dublin: Irish Museum of Modern Art, 2008. Textos por Enrique Juncosa.

- Prospect.1 New Orleans. New Orleans: Louisiana State Museum; Old US Mint; Brooklyn: Picturebox, 2008. Editado por Barbara Bloemink e Dan Cameron.

- Quando vidas se tornam forma: diálogos com o future Brasil / Japão. São Paulo: Museu de Arte Moderna de São Paulo, 2008. Textos por Felipe Chaimovich e Yuko Hasegawa.

2007

- Ateliês do Rio de Janeiro. Rio de Janeiro: Francisco Alves, 2007. Textos por Carlos Leal e Marc Pottier, conversas com Oswalldo Sérgio Correa da Costa.

- Auto-retrato do Brasil. Rio de Janeiro: Bem-te-vi Produções Literárias, 2007. Textos por Stella Teixeira Barros, Frederic Morais e Beatriz Milhazes.

- Coleção Itaú Contemporâneo. Arte no Brasil de 1981 a 2006. São Paulo: Itaú Cultural, 2007. Editado por Teixeira Coelho,

- Monsoon Art Collection. Londres: Monsoon Art Collection, 2007. Editado por Victoria Brooks e Joanna Stella-Sawicka.

- Open Spaces: Art in public realm in London, 1995-2005. Londres: Arts Council England and Central London Partnership, 2005. Editado por Jemima Montagu.

\section{6}

- Art and Design and Everything Else. Shangai: 6th Shangai Biennale - Hyper Design, 2006. Texto por Jonathan Watkins.

- Beatriz Milhazes, Cor e Volúpia. Rio de Janeiro: Editora Francisco Alves, 2006. Texto por Paulo Herkenhoff.

- Arte em Metrópolis. São Paulo: Instituto Tomie Ohtake; Curitiba: Museu Oscar Niemeyer, 2005. Texto por Adriano Pedrosa.

- Contemporânea Arte Artistas. São Paulo: Alles Trade Publications, 2006. Textos por Paula Alzugaray e Rosa de Luca.

- Desenhos/ Drawings: A-Z. Madeira: Collection Madeira Corporate Services, 2006. Textos por Alexandre Melo e Franz Manata.

- É HOJE na arte brasileira contemporânea: Coleção Gilberto Chateaubriand. Rio de Janeiro: Centro Cultural Santander Banespa, 2006. Texto por Fernando Cocchiarale. 
- A arte moderna no Brasil, o olhar do colecionador. Rio de Janeiro: Instituto Cultural Sergio Fadel Publications, 2006.

- Off the Shelf: New forms in Contemporary Artists'Books. Poughkeepsie: Frances Lehman Loeb Art Center; Vassar College, 2006. Textos por Mary-Kay Lombino.

- Um século de Arte Brasileira: Coleção Gilberto Chateaubriand. São Paulo: Pinacoteca do Estado, 2006. Texto por Marcus de Lontra Costa.

\section{5}

- Art Now 2. Cologne: Taschen, 2005. Editado por Uta Grosenick.

- Blumenmythos / Flower Myth: Von Vincent Van Gogh bis Jeff Koons. Basel: Foundation Beyeler, Wolfratshausen, Minerva, 2005. Textos por Philippe Büttner e Ulf Küster.

- POPulence. Cleveland: Museum of Contemporary Art Cleveland; Winston-Salem: Southeastern Center for Contemporary Art; Houston: Blaffer Art Museum; University of Houston, 2005. Textos por Susan Conaway, David Pagel e Terrie Sultan.

- Works on Paper. Berlin: Galerie Max Hetzler, 2005. Texto por Kirsty Bell.

- 24a Arte Pará 2005: Contemporâneo. Belém: Fundação Romulo Maiorana, 2005. Texto por Paulo Herkenhoff..

\section{4}

- $26^{a}$ Bienal de São Paulo. São Paulo: Fundação Bienal de São Paulo, 2004. Textos por Jacopo Crivelli Visconti e Alfons Hug.

- Beatriz Milhazes. Bigna:, Domaine de Kerguenhennec, Centre d'Art Contemporain, 2004. Textos por Frederic Paul e Simon Wallis, conversas com Christian Lacroix.

- Carnaval. Rio de Janeiro: Centro Cultural Banco do Brasil, 2004.

- Estratégias Barrocas: Arte Contemporáneo brasileña. Quito, Centro Cultural Metropolitano, 2004. Textos por Jacopo Crivelli Visconti.

- Onde está você, geração 80? Rio de Janeiro: Centro Cultural Banco do Brasil, 2006. Textos por Alexx Flemnming e Marcus de Lontra Costa.

- The encounters in the 21st Century: Polyphony - Emerging Resonances. Kanazawa: 21 st Century Museum of Contemporary Art, 2004. Textos por Yuko Hasegawa. 
- Critical Perspectives on contemporary paitings: hybridity, hegemony, historicism. Liverpool: Liverpool University Press; Tate Liverpool, 2003. Editado por Jonathan Harris.

- Base \& Awesome, Conversaions on Contemporary Paiting (Bernard Frize, Katharina Groose \& Beatriz Milhazes). Birmingham: Ikon Gallery; London: Central Books, 2003. Editado por Yvonne Hundle e Mike Stanley.

- Cream 3: Contemporary Art in Culture, 10 curators, 100 contemporary artists, 10 source artists. Londres: Phaidon Press, 2003.

- Heisskalt: Aktuelle Malerei aus der Smmlung Scharpff. Hamburgo: Hamburger Kunstalle; Stuggart, Staatgalerie; Ostfildern, HATJE Cantz, 2003. Editado por Christoph Heinrich e Nina Zimmer.

- Sonhos desperdiçados: Beatriz Milhazes. Rosângela Rennó. Brazillian Pavillion. 50 Biennale di Venezia. São Paulo: Fundação Bienal, 2003. Textos de Jacopo Crivelli Visconti, Alfons Hug e Manoel Francisco Pires da Costa.

- 50th International Art Exhibition: Dreams and Conflits - The Dictatorship of the Viewer. Veneza: La Biennale di Venezia, 2003. Editado por Francesco Bonami e Maria Luisa Frisa.

2002

- Beatriz Milhazes: Mares do Sul. Rio de Janeiro: Centro Cultural Banco do Brasil, 2002. Textos por Paulo Herkenhoff, Adriano Pedrosa e Barry Schwabsky, conversa com Jonathan Watkins.

- Urgent Painting. Paris: Musée d'Art Moderne de la Ville de Paris, 2002. Editado por Suzanne Pagé, textos por Patricia Falguière, Julia Garimorth, Paulo Herkenhoff, et al.

- Bienal 50 anos 1951/2001. São Paulo: Bienal Internacional de São Paulo, 2002. Textos por Agnaldo Farias.

- Vitamin P: New Perspectives in Paintings. Londres: Phaidon Press, 2002. Editado por Barry Schwabsky. 
- Beatriz Milhazes. Bimingham: Ikon Gallery; Birmingham Museum of Modern Art, 2001. Textos por Paulo Herkenhoff e David Moos.

- Espelho Cego: Seleção de uma Coleção Contemporânea. Rio de Janeiro: Centro Cultural Paço Imperial; São Paulo: Museu de Arte Moderna de São Paulo, 2001. Textos por Dan Cameron, Lauro Cavalcanti e Márcia Fortes.

- F(r)icciones: Versiones del Sur. Madrid: Museo Nacional Centro de Arte Reina Sofia, 2001. Textos por Ivo Mesquita e Adriano Pedrosa.

- Hybrids: International Contemporary Paiting. Liverpool: Tate Liverpool, 2001. Textos por David Ryam e Simon Wallis.

- Operativo. Cidade do México: Museu Tamayo Arte Contemporáneo, 2001.

- Rotativa: Fase 1. São Paulo: Galeria Fortes Vilaça, 2001. Textos por Márcia Fortes e Alessandra Vilaça.

2000

- Marcas do Corpo, Dobras da alma. São Paulo: Mostra de Gravura de Curitiba, 2000. Textos por Veronica Cordeiro, Paulo Herkenhoff e Adriano Pedrosa.

- Projects 70: Jim Hodges, Beatriz Milhazes, Faith Ringgold. Nova Iorque: Museu de Arte Moderna, 2000. Texto por Fereshteh Daftari.

1999

- Impressões Contemporâneas: Mostra Rio Gravura. Rio de Janeiro: Centro Cultural Paço Imperial, 1999. Textos por Stella Teixeira de Barros e Rubem Grillo.

1998

- $16^{\circ}$ Salão Nacional de Artes Plásticas. Rio de Janeiro: Museu de Arte Moderna do Rio de Janeiro; Fundação Nacional de Arte, 1998.

- Abstract Paiting Once Removed. Houston: Contemporary Arts Museum, 1998. Editado por Dan Friis-Hansen.

- Arte Contemporânea Brasileira: um e/entre outro/s - XXIV Bienal Internacional de São Paulo. São Paulo: Fundação Bienal de São Paulo, 1998. Editado por Paulo Herkenhoff e Adriano Pedrosa. 
- Decorativo Strategies. Annandale-on Hudson: Center for Curatorial Studies, Bard College, 1998. Texto por Georgia Lobacheff.

- Der Brasilianishe Blick: Sammlung Gilberto Chateubriand. Berlin: DeutschBrasilianische Kulturelle Vereinigung in Berlin, 1998. Editado por Cornelia Gerner e Sabine Vogel.

- Every day: 11th Biennale of Sydney. Sydney: The Biennale of Sydney, 1998. Editado por janathan Watkins.

- Perfil da Coleção Itaú. São Paulo: Instituto Itaú Cultural, 1998. Texto por Stella Teixeira de Barros.

1997

- Theories of the Decorative: Abstraction and Ornament in Contemporary Paiting. Edinburgh: Inverleith House; Wichita; Edwin A. Ulrich Museum of Art; Wichita State University, 1997. Texto por David Moos.

1996

- Beatriz Milhazes. São Paulo: Galeria Camargo Vilaça, 1996. Texto por Adriano Pedrosa.

- Latin American Art of the Twentieth Century. London: Phaidon Press, 1996. Editado por Edward J. Sullivan.

1995

- Carnegie International 1995. Pittsburgh: The Carnegie Museum of Art, 1995. Texto por Richard Armstrong e Paolo Morsiani.

- Cronologia das Artes Plásticas no Rio de Janeiro 1816-1994. Rio de Janeiro: Topbooks Editora, 1995. Texto por Frederico Morais.

- Décimo Quarto Arte Pará. Belém: Galeria Romulo Maiorama, 1995. Texto por Paulo Herkenhoff.

- Panorama da Arte Brasileira. São Paulo: Museu de Arte Moderna de São Paulo; Rio de Janeiro: Museu de Arte Moderna do Rio de Janeiro, 1995. Textos por Cacilda Teixeira da Costa, Ivo Mesquita e Milú Villela. 
- Regards d'Amérique Latine. Genève: Galerie d'Art Actuel Regard, 1995. Texto por Jacques Leenhardt.

- Transatlantica: The America- Europa non representative. Caracas: Museo Alejandro Otero, 1995. Textos por Ruth Auerbach, Paulo Herkenhoff e Jacob Karpio.

1994

- Beatriz Milhazes. Monterrey: Galeria Ramis Barquet, 1994. Texto por Paulo Herkenhoff.

- Beatriz Milhazes: Atelier FINEP. Rio de Janeiro: Centro Cultural Paço Imperial, 1994. Texto por Stella Teixeira de Barros.

- Pequeño Formato Latinoamericano 94. San Juan: Luigi Marrozzini Gallery, 1994. Texto por Luigi Marrozzini.

- The exchange Show: Twelve Painters from San Francisco and Rio de Janeiro. San Francisco: Center for the Arts; Rio de Janeiro, Museu de Arte Moderna do Rio de Janeiro, 1994.

- 1993

- Beatriz Milhazes: Pinturas Recentes. Caracas: Sala Alternativa Artes Visuales; São Paulo: Galeria Camargo Vilaça, 1993. Texto por Stella Teixeira de Barros.

- Ultramodern: The Art of Contemporary Brazil. Washington, DC: National Museum of Women in the Arts, 1993. Textos por Aracy Amaral e Paulo Herkenhoff.

1992

- Eco Arte. Rio de Janeiro: Museu de Arte Moderna do Rio de Janeiro, 1992. Texto por Charles Merewether.

\section{1}

- Beatriz Milhazes: Pinturas. São Paulo: Subdistrito Comercial de Arte, 1991. Texto por Luiz Ernesto.

- Brasil: La nueva generación. Caracas: Fundación museo de Bellas Artes, 1991. Texto por Aracy Amaral. 
- BR/80 Pintura Brasil Década 80. Rio de Janeiro: Fundação Casa França-Brasil; São Paulo: Instituto Cultural Itaú, 1991.

1989

- II Bienal Internacional de Pintura. Cuenca: Museo de Arte Moderno, 1989. Editado por Rene Cardoso Cegarra.

- Cristina Canale, Cláudio Fonseca, Beatriz Milhazes, Luiz Pizzarro e Luiz Zerbini. São Paulo: Museu de Arte Contemporânea da Universidade de São Paulo, 1989. Texto por Fernando Cocchiarale.

1988

- $10^{\circ}$ Salão Nacional de Artes Plásticas. Rio de Janeiro: Fundação Nacional de Arte; Museu de Arte Moderna do Rio de Janeiro, 1988.

- Descendo a serra: dez artistas de Minas Gerais no Rio de Janeiro. Subindo a serra: dez artistas do Rio de Janeiro em Minas Gerais. Rio de Janeiro: Centro Cultural Cândido Mendes, 1988. Textos por Marcus de Lontra Costa.

1986

- Pinturas. Niterói: Galeria de arte da UFF, 1986. Texto por Paulo Roberto Leal.

1985

- $\quad 8^{\circ}$ Salão Nacional de Artes Plásticas. Rio de Janeiro: Fundação Nacional de Arte; Museu de Arte Moderna do Rio de Janeiro, 1985.

1984

- $7^{\circ}$ Salão Nacional de Artes Plásticas. Rio de Janeiro: Museu de Arte Moderna do Rio de Janeiro, 1984.

- Como vai você, Geração 80? Special Edition of Módulo Magazine. Rio de Janeiro: Escola de Artes Visuais do Parque Lage; INAP/FUNARTE, 1984. Textos por Paulo Roberto Leal, Marcus de Lontra Costa, Frederico Morais e Roberto Pontual. 
1983

- $6^{\circ}$ Salão Internacional de Artes Plásticas. Rio de Janeiro: Museu de Arte Moderna do Rio de Janeiro, 1983. 